PNNL-11989, Rev. 1

\title{
Integrated Monitoring Plan for the Hanford Groundwater Monitoring Project
}
M. J. Hartman
D. R. Newcomer
P. E. Dresel
E. C. Thornton

September 1999

Prepared for

the U.S. Department of Energy

under Contract DE-AC06-76RLO 1830

Pacific Northwest National Laboratory

Richland, Washington 99352 
. 


\section{DISCLAIMER}

This report was prepared as an account of work sponsored by an agency of the United States Government. Neither the United States Government nor any agency thereof, nor any of their employees, make any warranty, express or implied, or assumes any legal liability or responsibility for the accuracy, completeness, or usefulness of any information, apparatus, product, or process disclosed, or represents that its use would not infringe privately owned rights. Reference herein to any specific commercial product, process, or service by trade name, trademark, manufacturer, or otherwise does not necessarily constitute or imply its endorsement, recommendation, or favoring by the United States Government or any agency thereof. The views and opinions of authors expressed herein do not necessarily state or reflect those of the United States Government or any agency thereof. 


\section{DISCLAIMER}

Portions of this document may be illegible in electronic image products. Images are produced from the best available original document. 


\section{Summary}

Groundwater is monitored at the Hanford Site to fulfill a variety of state and federal regulations, including the Atomic Energy Act of 1954; the Resource Conservation and Recovery Act of 1976; the Comprehensive Environmental Response, Compensation, and Liability Act of 1980; and Washington Administrative Code. Separate monitoring plans are prepared for various requirements, but sampling is coordinated and data are shared among users to avoid duplication of effort. The U.S. Department of Energy manages these activities through the Hanford Groundwater Monitoring Project.

This document is an integrated monitoring plan for the groundwater project. It documents well and constituent lists for monitoring required by the Atomic Energy Act of 1954 and its implementing orders; includes other, established monitoring plans by reference; and appends a master well/constituent/ frequency matrix for the entire site.

The objectives of monitoring fall into three general categories: plume and trend tracking, treatment/ storage/disposal unit monitoring, and remediation performance monitoring. Criteria for selecting Atomic Energy Act of 1954 monitoring networks include locations of wells in relation to known plumes or contaminant sources, well depth and construction, historical data, proximity to the Columbia River, water supplies, or other areas of special interest, and well use for other programs. Constituent lists were chosen based on known plumes and waste histories, historical groundwater data, and, in some cases, statistical modeling. Sampling frequencies were based on regulatory requirements, variability of historical data, and proximity to key areas. For sitewide plumes, most wells are sampled every 3 years. Wells monitoring specific waste sites or in areas of high variability will be sampled more frequently. 


\section{Contents}

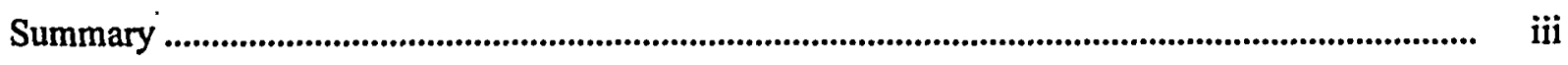

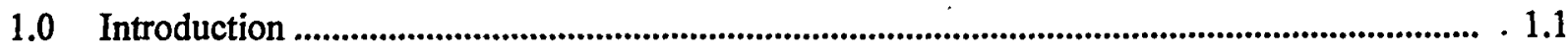

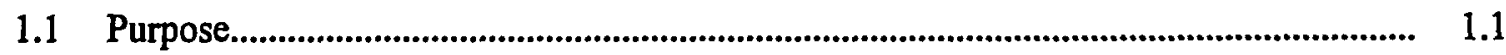

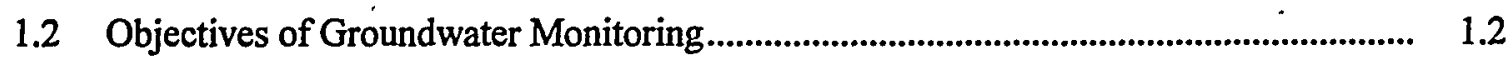

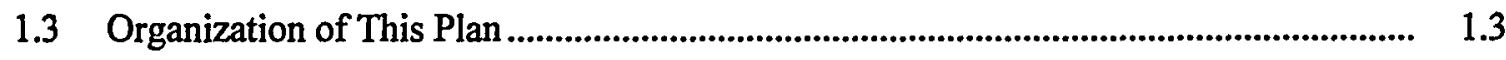

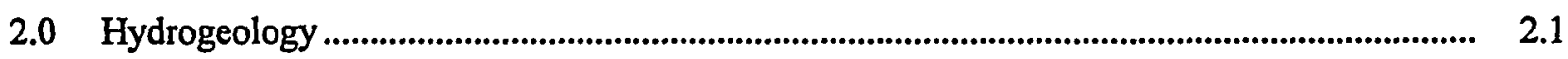

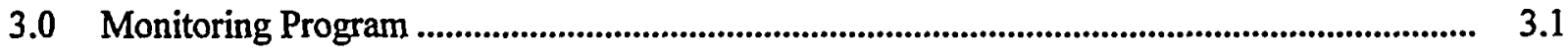

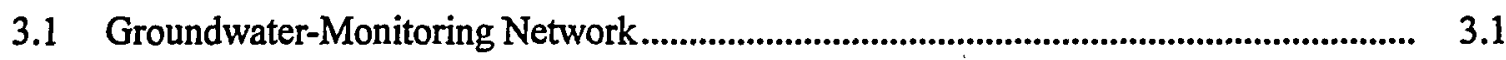

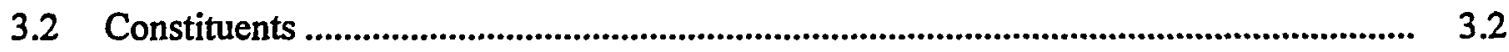

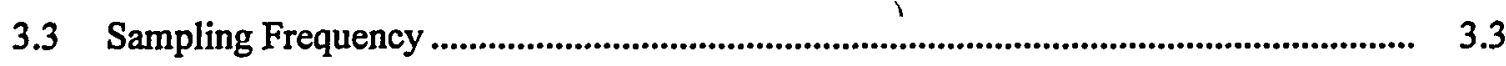

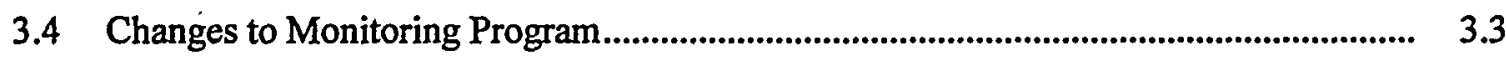

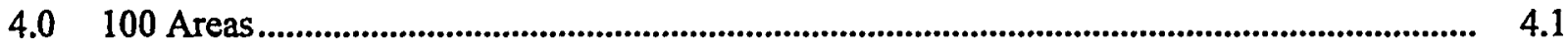

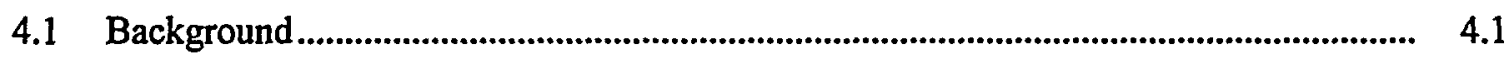

4:1.1 Waste Sites, Discharges, and Groundwater Operable Units................................ 4.1

4.1.2 Groundwater-Monitoring Requirements and History.......................................... 4.1

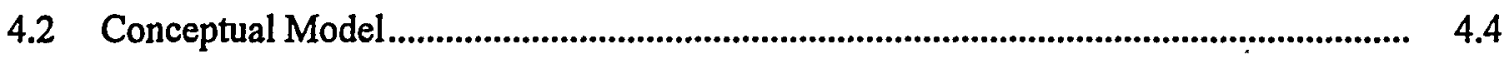

4.3 Monitoring Program ..................................................................................................... 4.7

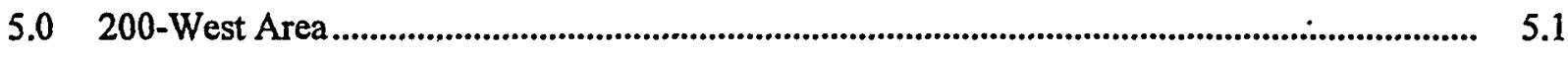

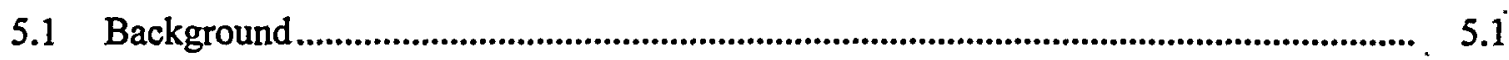

5.1.1 Waste Sites, Discharges, and Groundwater Operable Units................................ 5.1

5.1.2 Groundwater-Monitoring Requirements and History...................................... 5.1

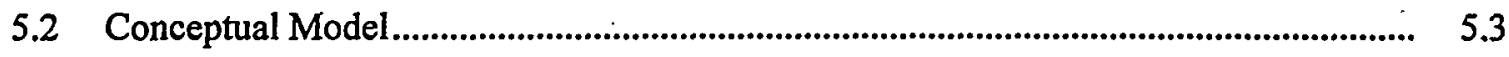

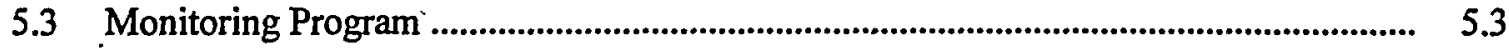




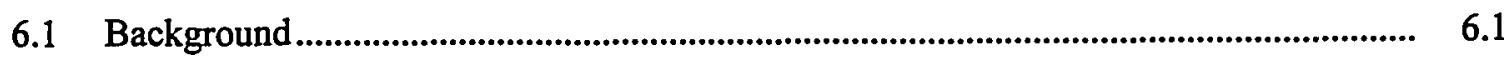

6.1.1 Waste Sites, Discharges, and Groundwater Operable Units................................. 6.1

6.1.2 Groundwater-Monitoring Requirements and History....................................... 6.3

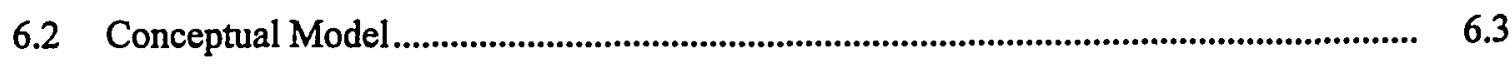

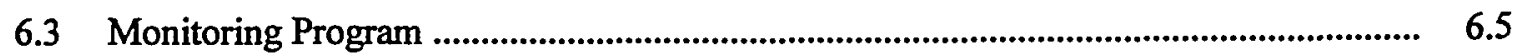

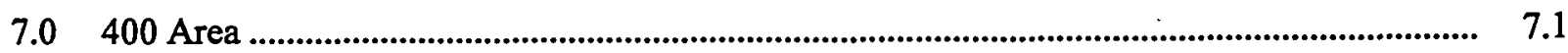

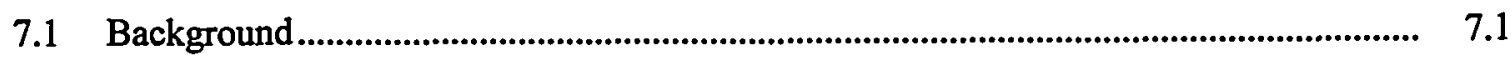

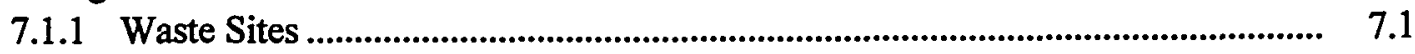

7.1.2 Groundwater-Monitoring Requirements and History.................................... 7.1

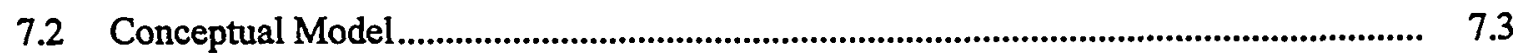

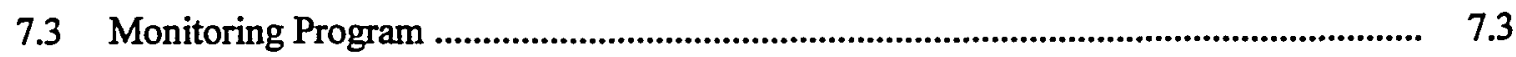

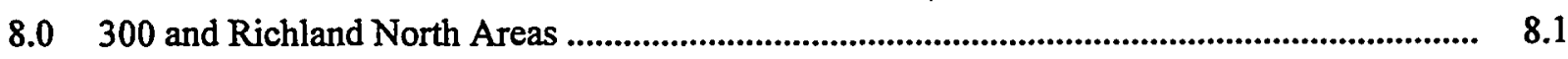

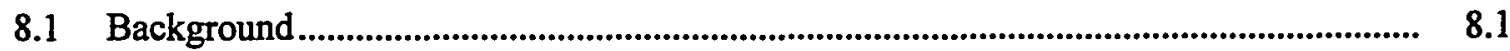

8.1.1 Waste Sites, Discharges, and Groundwater Operable Units............................. 8.1

8.1.2 Offsite Sources ................................................................................................ 8.3

8.1.3 Groundwater-Monitoring Requirements and History..................................... 8.4

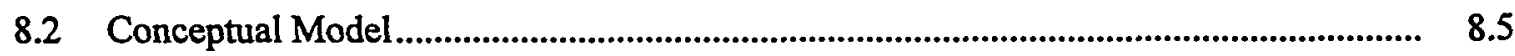

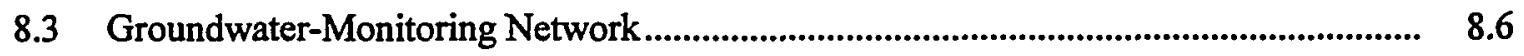

9.0600 Area Non-Operational Monitoring Activities........................................................ 9.1

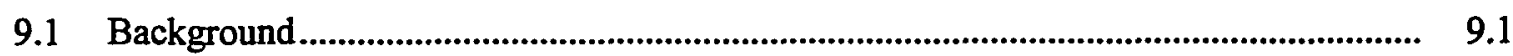

9.1.1 Waste Sites ...................................................................................................... 9.1

9.1.2 Groundwater-Monitoring Requirements and History...................................... 9.2

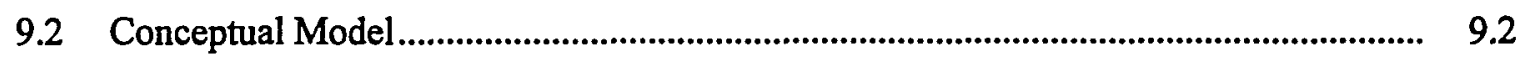

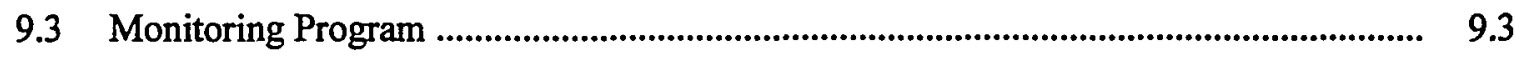

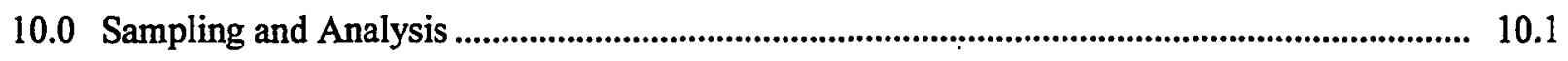

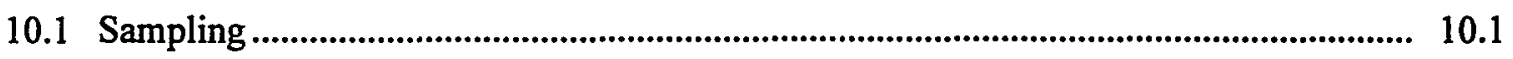




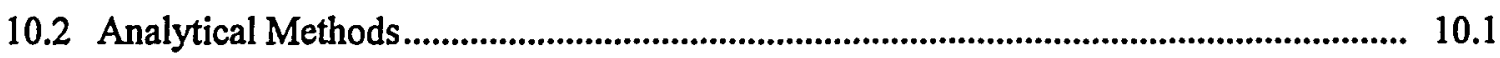

10.3 Quality Assurance and Quality Control .................................................................. 10.1

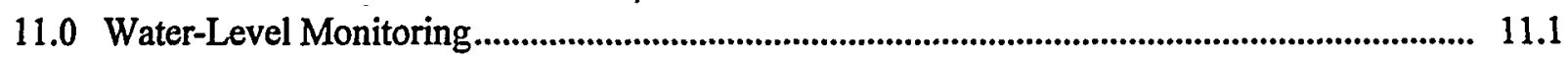

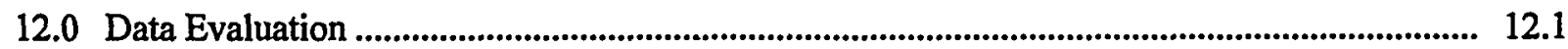

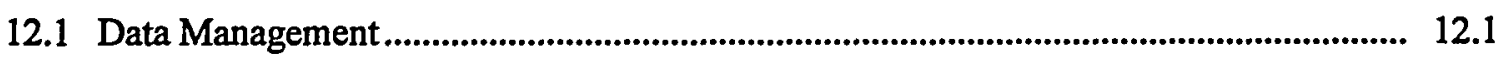

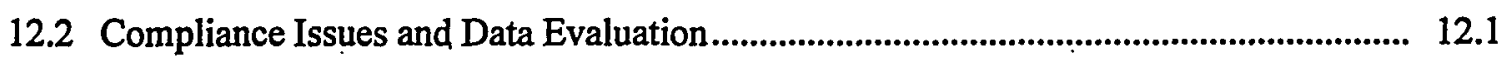

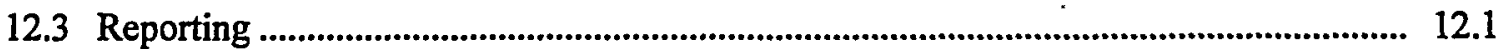

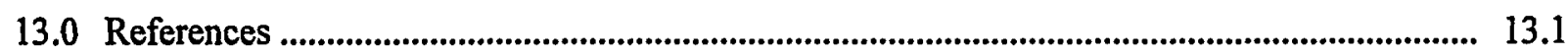

Appendix A - Sampling Matrix for Hanford Groundwater Monitoring Project ................................ A.1 


\section{Figures}

2.1 Comparison of Generalized Hydrogeologic and Geologic Stratigraphy ................................. 2.2

2.2 Hanford Site and Outlying Areas Water-Table Map, June 1998 ........................................ 2.3

2.3 Distribution of Major Radionuclides in Groundwater at Concentrations Above Maximum Contaminant Levels or Interim Drinking Water Standards, Fiscal Year 1998.

2.4 Distribution of Major Hazardous Chemicals in Groundwater at Concentrations Above Maximum Contaminant Levels, Fiscal Year 1998

4.1 Conceptual Model of Subsurface Contamination in the 100 Areas.

4.2 Groundwater Project Well Locations: 100-B,C Area

4.3 Groundwater Project Well Locations: 100-K Area

4.4 Groundwater Project Well Locations: 100-N Area

4.5 Groundwater Project Well Locations: 100-D Area

4.6 Groundwater Project Well Locations: 100-H Area

4.7 Groundwater Project Well Locations: 100-F Area.

4.8 Groundwater Project Well Locations: 600 Area.

5.1 Groundwater Project Well Locations: 200-West Area

6.1 Locations of 200-East Area Guard Wells

6.6

6.2 Groundwater Project Well Locations: 200-East Area

7.1 Groundwater Project Well Locations: 400 Area.

7.2

8.1 Groundwater Project Well Locations: 300 and Richland North Areas.

9.1 Groundwater Project Well Locations: Central Landfill Vicinity.

9.4 


\section{Tables}

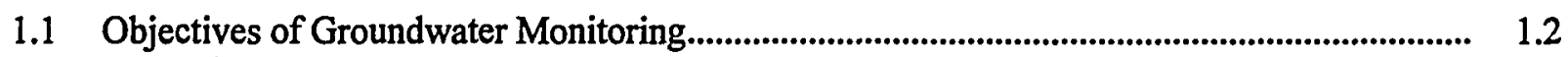

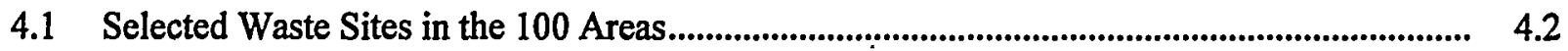

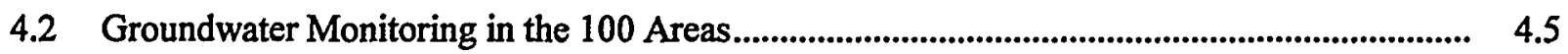

5.1 Selected Waste Sites in the 200-West Area.............................................................................. 5.2

6.1 Selected Waste Sites in and Downgradient of the 200-East Area ........................................ 6.2

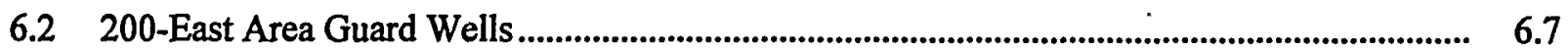

8.1 Selected Waste Sites in the 300 and Richland North Areas .............................................. 8.3

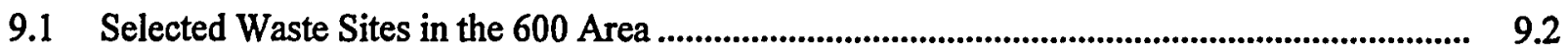

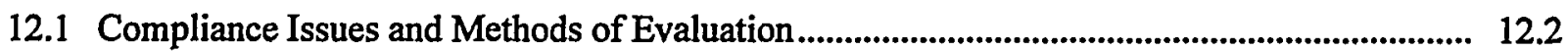




\subsection{Introduction}

Groundwater is monitored in hundreds of wells at the Hanford Site to fulfill a variety of requirements. Separate monitoring plans are prepared for various requirements, but sampling is coordinated and data are shared among users to avoid duplication of effort. The,U.S. Department of Energy (DOE) manages these activities through the Hanford Groundwater Monitoring Project ("groundwater project"), which is the responsibility of Pacific Northwest National Laboratory. ${ }^{1}$ The groundwater project does not include all of the monitoring to assess performance of groundwater remediation or all monitoring associated with active facilities.

This document is the first integrated monitoring plan for the groundwater project and contains: well and constituent lists for monitoring required by the Atomic Energy Act of 1954 and its implementing orders ("surveillance monitoring"); other, established monitoring plans by reference; and a master well/ constituent/frequency matrix for the entire Hanford Site.

\subsection{Purpose}

The purpose of this plan is to provide a venue to integrate groundwater monitoring for various requirements on the Hanford Site. Specific objectives of this plan are the following:

- design and describe monitoring well networks, constituent lists, sampling frequency, and quality assurance/quality control for the surveillance monitoring network; explain criteria used to design the program

- encompass Resource Conservation and Recovery Act of 1976 (RCRA), Comprehensive Environmental Response, Compensation, and Liability Act of 1980 (CERCLA), Washington Administrative Code (WAC) regulations, and other monitoring plans by reference

- provide well, constituent, and sampling frequency lists for all groundwater monitoring on the site.

This plan is subordinate to the Environmental Monitoring Plan, U.S. Department of Energy, Richland Operations Office (DOE 1997), which is required by DOE Orders, and the Hanford Site Ground-Water Protection Management Plan (Barnett et al. 1995a). This plan describes how DOE will implement the groundwater-monitoring requirements described in those documents.

Recently, efforts have been made to develop fully integrated monitoring programs to fill data needs for a variety of requirements using the data quality objectives process (e.g., in the 100-N and 200-East

\footnotetext{
${ }^{1}$ Pacific Northwest National Laboratory is operated by Battelle for DOE.
} 
Areas). The results of these efforts are incorporated into this plan. Additional data quality objectivesbased networks will be developed in the future and will be incorporated into changes to the sampling schedule and future revisions of this plan.

\subsection{Objectives of Groundwater Monitoring}

The Environmental Monitoring Plan (DOE 1997) lists the purposes and objectives of groundwater monitoring and the groundwater project. These purposes and objectives fall into three general categories: 1) plume and trend tracking, 2) monitoring of treatment/storage/disposal units, and 3) independent assessment of performance monitoring for groundwater remediation activities (Table 1.1).

Plume and trend tracking are the primary objectives of surveillance monitoring. Treatment/storage/ disposal unit monitoring includes units regulated under RCRA or state codes (recently active sites), CERCLA (past-practice sites), and the Atomic Energy Act of 1954. Monitoring associated with remediation activities is the responsibility of the environmental restoration contractor, but the groundwater project is responsible for "providing continuing, independent assessment of groundwater remediation activities" (DOE 1997).

Table 1.1. Objectives of Groundwater Monitoring (DOE 1997)

\section{Plume and Trend Tracking}

Determine baseline conditions of groundwater quality and quantity.

Characterize and define hydrogeologic, physical, and chemical trends in the groundwater system.

Identify existing and potential groundwater contamination sources.

Assess existing and emerging groundwater quality problems.

Evaluate existing and potential offsite impacts of groundwater contaminants.

Provide data on which decisions can be made conceming land-disposal practices and management and protection of groundwater resources.

\section{Treatment/Storage/Disposal Unit Monitoring}

Demonstrate compliance with applicable regulations and orders (RCRA, WAC).

Provide data to permit early detection of groundwater pollution or contamination.

Groundwater Remediation Performance Monitoring

Provide continuing, independent assessment of groundwater remediation activities (groundwater remediation and performance monitoring are conducted by the environmental restoration contractor; currently, Bechtel Hanford Inc.; groundwater project provides independent assessment). 


\subsection{Organization of This Plan}

A brief overview of the hydrogeology of the Hanford Site is provided in Chapter 2.0 as background for the remainder of the plan. Chapter 3.0 describes the monitoring program, with an explanation of criteria for choosing well networks, constituent lists, and sampling frequency. Chapters 4.0 through 9.0 describe the waste sites, monitoring history, and a conceptual model of the movement of contaminants for each geographic region of the site. Chapter 10.0 describes the sampling and analysis plan, including methods for sampling and analysis, quality assurance, and quality control. Chapter 11.0 describes the water-level-monitoring program; Chapter 12.0 describes data management, compliance issues, and reporting; followed by Chapter 13.0 , the references cited herein.

An integrated monitoring matrix is presented in Appendix A, showing all wells to be sampled by the groundwater project for various requirements (e.g., sitewide surveillance, RCRA, CERCLA). The appendix.will be updated at least annually. 


\subsection{Hydrogeology}

The hydrogeology of the Hanford Site has been described in many documents (e.g., Chapter 3.0 in Hartman and Dresel 1998). A brief summary is provided here for the reader's convenience.

The uppermost aquifer beneath most of the Hanford Site is unconfined and composed of unconsolidated to semiconsolidated sands and gravels deposited on basalt bedrock. In some areas, deeper parts of the aquifer are locally confined by layers of silt and clay. Confined aquifers occur within the underlying basalt flows and associated sedimentary interbeds. A simplified stratigraphic column is illustrated in Figure 2.1.

Groundwater in the unconfined aquifer system generally moves from recharge areas along the western boundary of the site to the east and north toward the Columbia River, which is the major discharge area. This natural flow pattern was altered by the formation of groundwater mounds created by large volumes of artificial recharge at wastewater-disposal facilities. These mounds are declining, and groundwater flow is gradually returning to earlier patterns. Figure 2.2 shows a water-table map for June 1998.

The extent of major radionuclide contaminants in groundwater in 1998 is illustrated in Figure 2.3. Tritium, iodine-129, technetium-99, uranium, and strontium-90 were present at levels above drinking water standards. Carbon-14, cesium-137, and plutonium exceeded standards in smaller areas. The extent of major hazardous chemical constituents in 1998 is shown in Figure 2.4. The most significant of these include carbon tetrachloride, chromium, and nitrate. Trichloroethylene and arsenic are also elevated in smaller areas. 


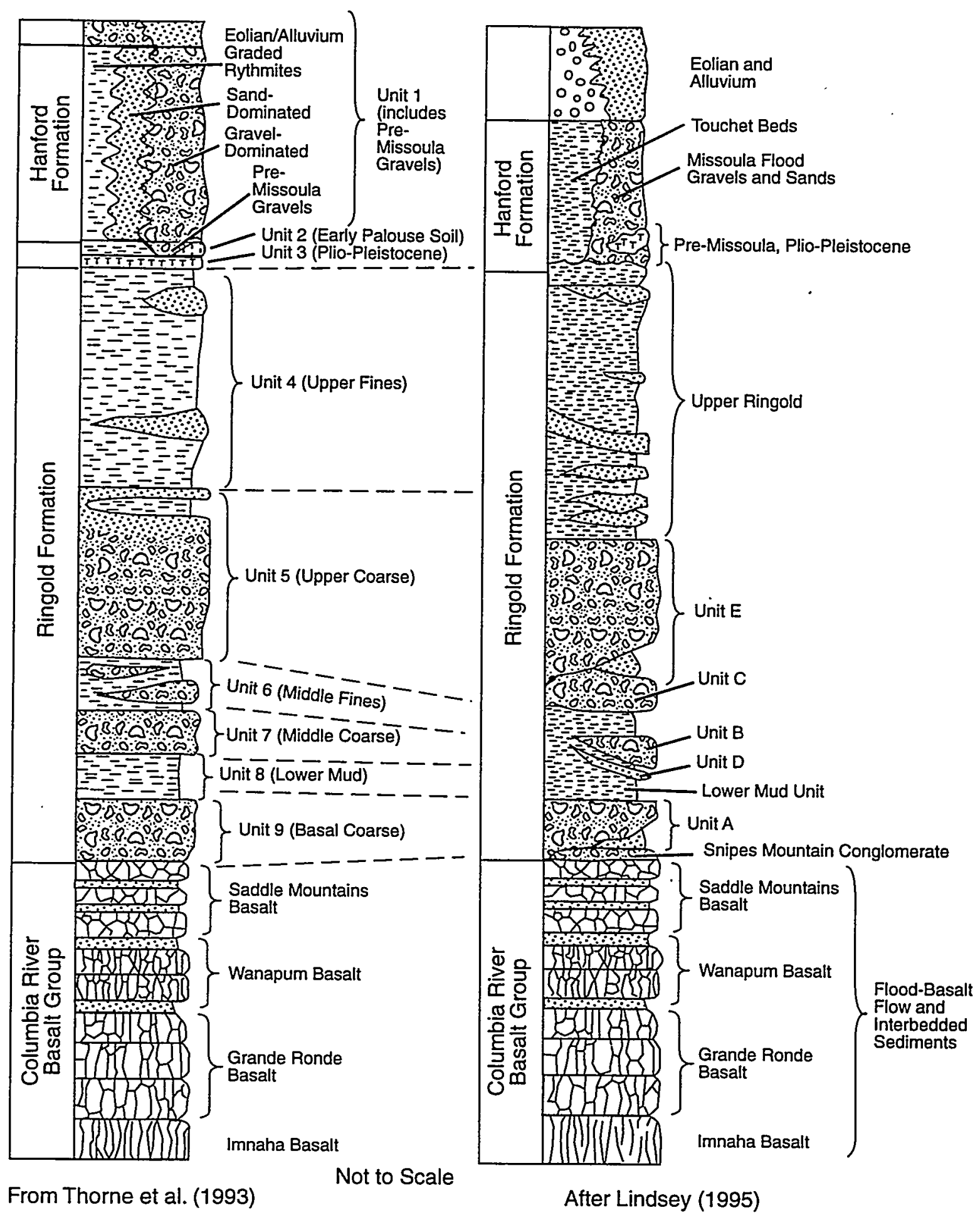

RG980900050.2

Figure 2.1. Comparison of Generalized Hydrogeologic and Geologic Stratigraphy 


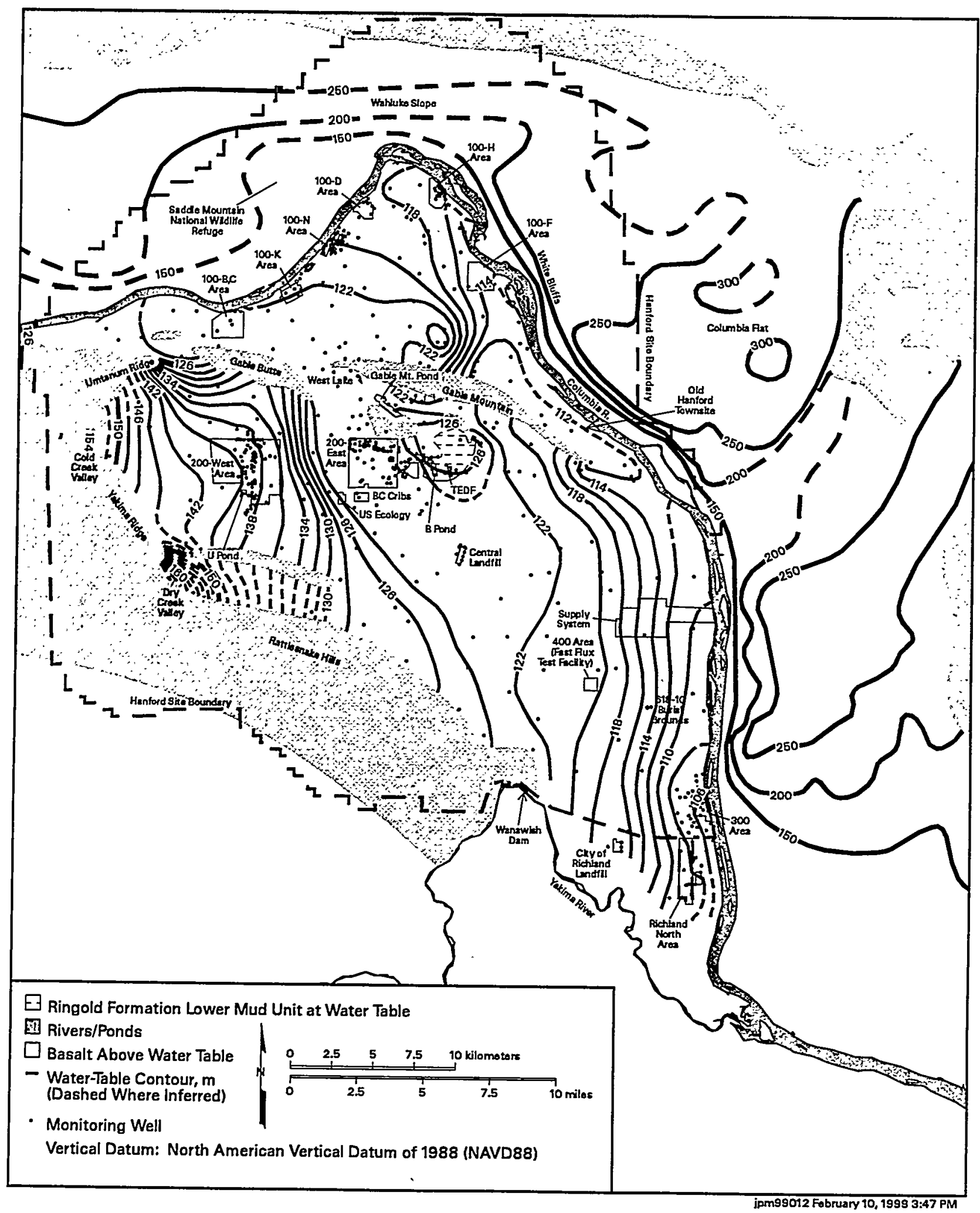

Figure 2.2. Hanford Site and Outlying Areas Water-Table Map, June 1998 (from Hartman 1999) 


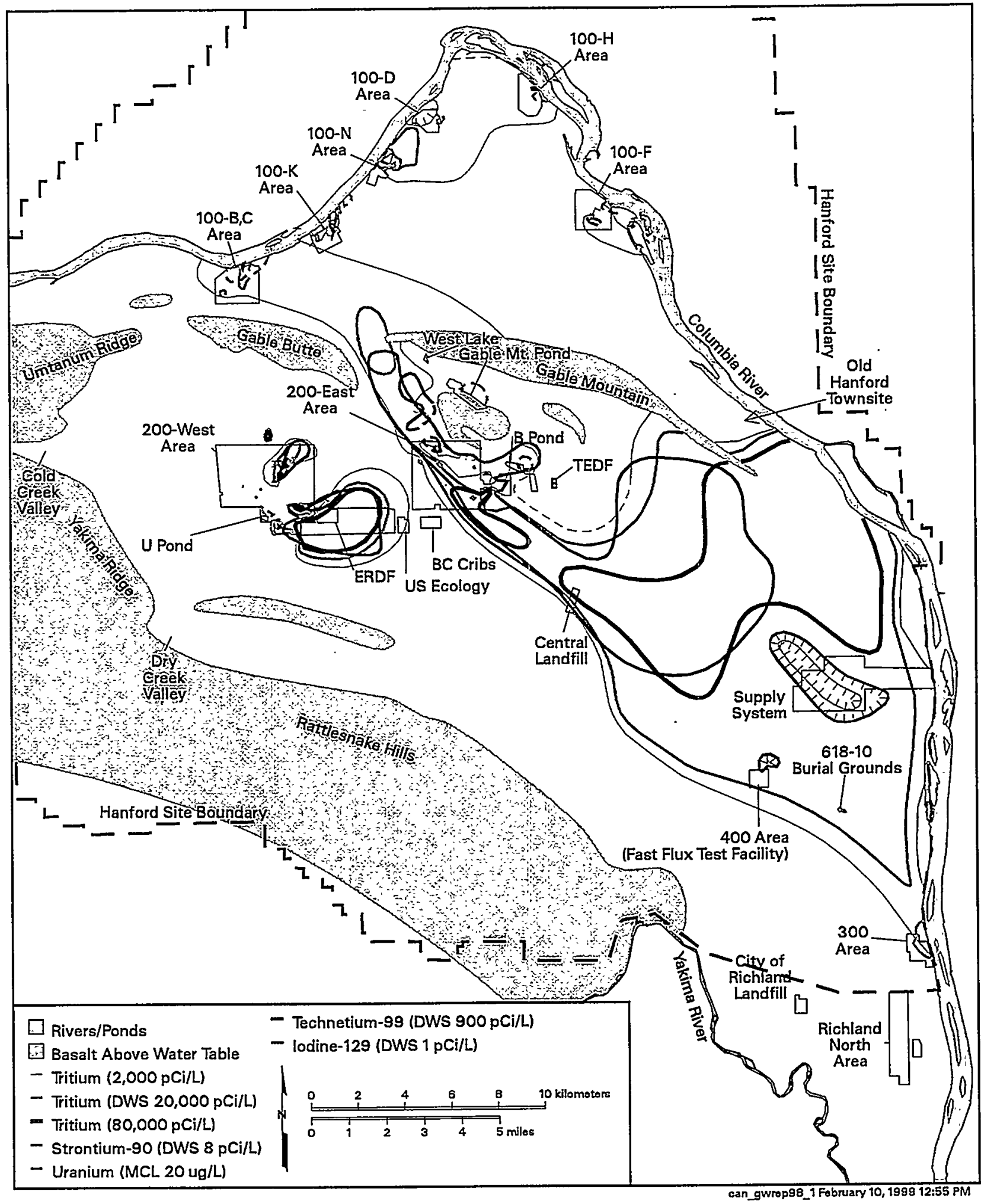

Figure 2.3. Distribution of Major Radionuclides in Groundwater at Concentrations Above Maximum Contaminant Levels (MCLs) or Interim Drinking Water Standards (DWSs), Fiscal Year 1998 (Hartman 1999) 


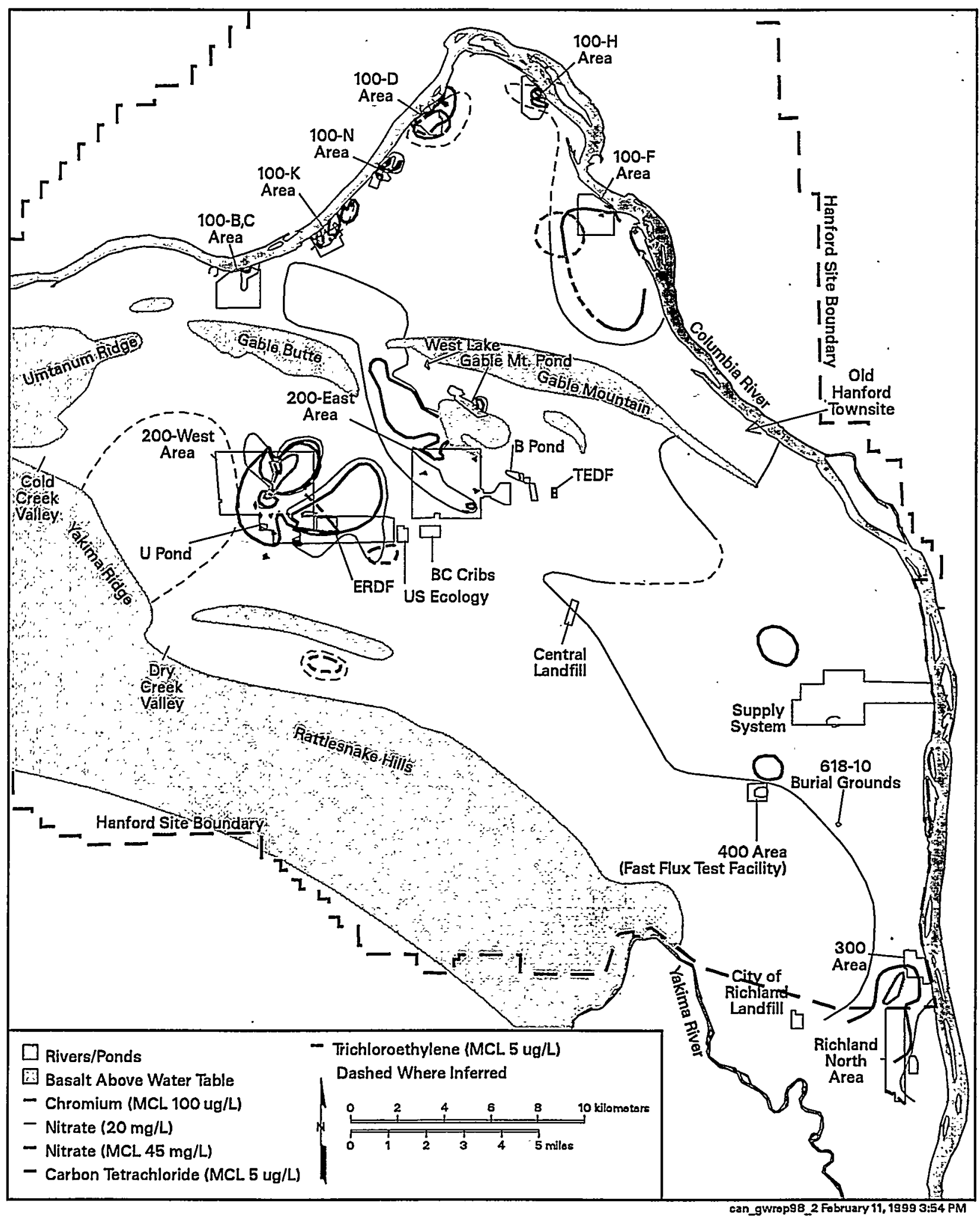

Figure 2.4. Distribution of Major Hazardous Chemicals in Groundwater at Concentrations Above Maximum Contaminant Levels (MCLs), Fiscal Year 1998 (Hartman 1999) 


\subsection{Monitoring Program}

The integrated sampling and analysis matrix for the groundwater project is given in Appendix A. The matrix was designed for use in fiscal year 2000, but also includes wells that will be sampled every 2 or 3 years, as discussed in Section 3.3. The matrix includes well name, sampling frequency, and constituents to be monitored. Additional details, such as schedule, analytical methods, etc., reside in a project database.

\subsection{Groundwater-Monitoring Network}

Wells on the Hanford Site are monitored in compliance with: 1) the Atomic Energy Act 1954 and its implementing orders ("surveillance monitoring"), 2) CERCLA operable units, 3) remedial action performance assessment, 4) RCRA, and 5) WAC permits. Monitoring networks for items 2 through 5 are defined in monitoring plans, interim records of decision (RODs), or change agreements listed in Chapters 4.0 through 8.0. Most of these monitoring networks are included in the monitoring matrix of Appen$\operatorname{dix} A$. The criteria for choosing wells for surveillance monitoring are discussed below.

1. Defining plumes - A representative areal distribution of wells within the plume is monitored, with an emphasis on wells with the highest concentrations of contaminants and wells near plume boundaries. Some wells in uncontaminated areas between plumes are also monitored to help control interpretation of plume boundaries and to monitor plume migration. Plumes migrating onto the site from offsite sources are also monitored (e.g., agricultural effects, Richland Landfill, Siemens Power Corporation). A geostatistical approach was employed to determine which wells should be sampled to track major plumes from the 200-East Area (discussed in Chapter 6.0).

2. Monitoring contaminant sources - Waste-disposal facilities not regulated by RCRA or the WAC are included in surveillance monitoring (e.g., 100-K Basins, 216-U-1 Crib). ${ }^{1}$ Wells downgradient of these facilities are monitored to detect their impact on groundwater.

3. Interval monitored - Most of the groundwater contamination on the Hanford Site is contained in the uppermost (unconfined) aquifer, so most of the monitoring wells are screened there. Newer wells installed for RCRA and CERCLA are screened across the water table and monitor the top 3 to $10 \mathrm{~m}$ of the unconfined aquifer. Wells that monitor a longer interval are less desirable because contami- . nants could be diluted from representative concentrations to below detection limits. A few wells monitor deeper intervals of the suprabasalt sediments or confined aquifers in the basalt. These wells are sampled to monitor whether contamination has migrated deeper in the hydrologic system.

${ }^{1}$ This type of monitoring has been called "operational monitoring" in the past. It is now considered part of surveillance monitoring. 
4. Historical data - Previous groundwater chemistry or water-level data in a well are useful for monitoring trends and for determining sampling frequency and constituent lists. Wells with historical data are preferable to those without.

5. Adequacy of well construction - Wells with poor seals, broken casing, or other problems may not provide representative data, and will be remediated or decommissioned.

6. Amount of water in the well - Declining water levels are causing some wells to go dry. Wells that are likely to contain sufficient water for sampling are chosen for the network.

7. Proximity to the Columbia River - In some cases, it is desirable to monitor wells very near the river shore to assess what concentrations of contaminants are entering the river. In other cases, it is more advantageous to choose wells farther inland to avoid fluctuations in concentration caused by bank storage effects.

8. Use by other requirements of the groundwater project.(e.g., RCRA, CERCLA) - Wells being sampled for other purposes are used for surveillance monitoring, where possible, for a more cost-effective program.

9. "Guard wells" - Key areas have been identified as being of special interest: bands of wells in Gable Gap and southeast of the 200-East Area were chosen to monitor contamination migrating out of the 200 Areas (discussed in Chapter 6.0), wells near the Columbia River, wells in the southern portion of the site near the City of Richland's North Well Field and recharge basins.

10. Performance assessment - The environmental restoration contractor (i.e., Bechtel Hanford, Inc.) conducts performance assessment monitoring in conjunction with remedial actions. The groundwater project is responsible for providing independent assessment of remedial actions, so wells near the remedial actions are included.

\subsection{Constituents}

Constituents are included in the sampling matrix of Appendix A. This matrix is an abbreviated version of the sampling matrix maintained by the groundwater project, which specifies various methods of analysis for some constituents.

The following criteria were considered to determine what analyses should be run on the samples for surveillance monitoring:

1. Proximity to known plumes or waste sites - If a well is located in a contaminant plume or downgradient of a plume, it is generally sampled for that contaminant. 
2. Historical data in well - Wells are generally not sampled for constituents that have not been detected . or are below some level of interest (e.g., drinking water standards) unless they are monitoring movement of a nearby plume.

3. Statistical modeling (discussed in Chapter 6.0).

4. Use for other requirements - If there is a choice of analytical method for a desired constituent, the method used for other monitoring purposes is chosen if it is satisfactory for surveillance monitoring.

5. State of Washington Department of Health constituents - Constituents, including total alpha, anions, total beta, gamma, iodine-129, technetium- 99 , tritium, and uranium isotopes, are co-sampled to provide a quality control check.

The choice of constituents for RCRA, CERCLA, and other monitoring requirements are based on waste history, permit conditions, and constituents of concern, as discussed in their monitoring plans.

\subsection{Sampling Frequency}

Sampling frequency for RCRA, CERCLA, and other monitoring requirements are determined by regulation, permits, or other agreements. Frequency for plume and trend tracking are based on the following criteria:

1. Variability of historical data - If previous concentrations are level or are on a steady trend, lessfrequent sampling (every 3 years) is sufficient. Wells with larger variability are sampled more frequently (annually or more often).

2. Proximity to key areas - Guard wells (see Section 3.1) and wells monitoring source areas are sampled more frequently.

3. Mobility of contaminants in groundwater - Contaminants with greater mobility (e.g., tritium) may be sampled more frequently than those that are not very mobile in groundwater (e.g., strontium-90).

\subsection{Changes to Monitoring Program}

As data are received and evaluated, changes will be made to the program, as needed. For example, if the concentration of a contaminant in a well increases suddenly, an additional sample may be collected and analyzed to confirm or refute the initial result. This type of "one-time" change may be made without revision of this plan.

Each year the well/constituent matrix in this plan will be reviewed for adequacy and revised, if necessary, for the following fiscal year. These revisions will incorporate any changes made to monitoring plans for RCRA, CERCLA, and other requirements. 


\subsection{Areas}

For the purposes of this plan, "100 Areas" describes that portion of the Hanford Site north of Gable Mountain and Gable Butte and south of the Columbia River and includes the six reactor areas ( $100-\mathrm{B}, \mathrm{C}$, $100-\mathrm{K}, 100-\mathrm{N}, 100-\mathrm{D}, 100-\mathrm{H}$, and 100-F [upstream to downstream]) and the 600 Area in between.

\subsection{Background}

\subsubsection{Waste Sites, Discharges, and Groundwater Operable Units}

Hundreds of waste sites have been identified in the 100 Areas, including fuel-storage or retention basins that leaked; effluent disposal cribs, ditches, and drains; and various spills or other unplanned releases. Those with site-specific monitoring requirements and those that appear to have affected groundwater quality are listed in Table 4.1.

Most of the sites are inactive radiological or mixed waste sites, and will be cleaned up or monitored under the requirements of CERCLA or as RCRA past-practice sites. Five sites are regulated under RCRA because they were more recently active and contained dangerous waste constituents. Two sites currently discharge nondangerous effluent to the ground (sanitary waste and filter backwash in the 100-N Area).

Groundwater beneath the reactor areas and surrounding areas is divided into five groundwater operable units: 100-BC-5 (100-B,C Area), 100-KR-4 (100-K), 100-NR-2 (100-N), 100-HR-3 (100-D and 100-H), and 100-FR-3 (100-F Area). Pump-and-treat systems are active in the 100-K, 100-D, and 100-H Areas for chromium and in the 100-N Area for strontium-90. An in situ treatment system is active in the 100-D Area to chemically reduce hexavalent chromium to insoluble chromium compounds (redox manipulation). All of these remediation systems are considered interim actions; final remedial actions have not yet been selected.

\subsubsection{Groundwater-Monitoring Requirements and History}

Limited groundwater monitoring has been conducted in the reactor areas since the 1940s. Very few monitoring wells existed in the early decades but more were installed in the 100-K, 100-N, and $100-\mathrm{H}$ Areas in the 1970s and monitored for DOE requirements. RCRA monitoring began in the late 1980 s in the 100-N and 100-H Areas, and in the early 1990s in the 100-D Area, so additional wells were installed. CERCLA investigations and cleanup actions in the 1990s resulted in the installation of dozens more wells, spread among the reactor areas and the intervening 600 Area between the 100-D and 100-H Areas.

CERCLA interim actions in the 100-K, 100-N, 100-D, and 100-H Areas include specific monitoring requirements. CERCLA operable unit monitoring networks have also been defined for these areas and for 
Table 4.1. Selected Waste Sites in the 100 Areas $^{(a)}$

\begin{tabular}{|c|c|c|c|}
\hline Facility (period of use) & Waste Type & $\begin{array}{l}\text { Constituents of Interest } \\
\text { for Groundwater } \\
\text { Monitoring }\end{array}$ & Type of Site \\
\hline \multicolumn{4}{|c|}{ 100-B,C Area } \\
\hline $\begin{array}{l}116-B-11(1944-68) \text { and } \\
116-C-5(1952-69) \\
\text { retention basins }\end{array}$ & $\begin{array}{l}\text { Reactor coolant effluent; leaks } \\
\text { known }\end{array}$ & $\begin{array}{l}\text { Radionuclides, metals } \\
\text { strontium-90, chromium }\end{array}$ & Past-practice \\
\hline $\begin{array}{l}116-\mathrm{B}-1(1950-68) \text { and } \\
116-\mathrm{C}-1(1952-68) \text { waste- } \\
\text { disposal trenches }\end{array}$ & $\begin{array}{l}\text { Coolant effluent from fuel- } \\
\text { element failure (highly } \\
\text { radioactive) }\end{array}$ & Radionuclides & Past-practice \\
\hline $116-\mathrm{B}-5$ crib (1950-68) & Process effluent & Tritium & Past-practice \\
\hline $\begin{array}{l}\text { 118-B-6 burial ground } \\
(1950-53)\end{array}$ & Contaminated equipment & High-level tritium & Past-practice \\
\hline $\begin{array}{l}\text { Storage tanks and transfer } \\
\text { facilities (1944-69) }\end{array}$ & $\begin{array}{l}\text { Sodium dichromate leakage } \\
\text { from water-treatment facilities }\end{array}$ & Chromium & Past-practice \\
\hline \multicolumn{4}{|c|}{ 100-K Area } \\
\hline $\begin{array}{l}\text { Reactor buildings fuel- } \\
\text { storage basins (KE: 1955- } \\
71 ; 1975 \text {-present. KW: } \\
\text { 1955-71; 1981-present) }\end{array}$ & $\begin{array}{l}\text { Radionuclide-contaminated } \\
\text { water; leaks known }\end{array}$ & Tritium, strontium-90 & Active \\
\hline $\begin{array}{l}116-\mathrm{KE}-3(1955-71) \text { and } \\
116-\mathrm{KW}-2(1955-70) \\
\text { french drain/reverse well }\end{array}$ & $\begin{array}{l}\text { Effluent from fuel-storage } \\
\text { basin drainage collection }\end{array}$ & Tritium, strontium-90 & Past-practice \\
\hline $\begin{array}{l}116-\mathrm{KE}-1(1955-71) \text { and } \\
116-\mathrm{KW}-1(1955-71) \mathrm{cribs}\end{array}$ & Reactor condensate & Tritium, carbon-14 & Past-practice \\
\hline $116-\mathrm{K}-2$ trench $(1955-71)$ & $\begin{array}{l}\text { Reactor coolant water, } \\
\text { decontamination liquids }\end{array}$ & Chromium, strontium-90 & Past-practice \\
\hline $\begin{array}{l}116-\mathrm{KW}-3(1954-70) \text { and } \\
116-\mathrm{KE}-4(1955-71) \\
\text { retention basins }\end{array}$ & Reactor coolant; leaks known & Radionuclides & Past-practice \\
\hline $\begin{array}{l}\text { Storage tanks and transfer } \\
\text { facilities }\end{array}$ & $\begin{array}{l}\text { Sodium dichromate leakage } \\
\text { from } 183-\mathrm{KE} \text { and } 183-\mathrm{KW} \\
\text { water-treatment facilities }\end{array}$ & Chromium & Past-practice \\
\hline \multicolumn{4}{|c|}{ 100-N Area } \\
\hline $\begin{array}{l}\text { 1301-N liquid waste- } \\
\text { disposal facility (1963-85) }\end{array}$ & Reactor coolant & $\begin{array}{l}\text { Strontium-90, tritium, } \\
\text { minor hazardous } \\
\text { constituents }^{(\mathfrak{b})}\end{array}$ & $\begin{array}{l}\text { RCRA past- } \\
\text { practice }\end{array}$ \\
\hline $\begin{array}{l}\text { 1325-N liquid waste- } \\
\text { disposal facility (1983-89) }\end{array}$ & Reactor coolant & $\begin{array}{l}\text { Strontium-90, tritium, } \\
\text { minor hazardous } \\
\text { constituents }^{(b)}\end{array}$ & $\begin{array}{l}\text { RCRA past- } \\
\text { practice }\end{array}$ \\
\hline $\begin{array}{l}\text { 1324-NA percolation pond } \\
(1986-90)\end{array}$ & Treated demineralizer effluent & Sulfate, sodium, $\mathrm{pH}^{(\mathrm{b})}$ & $\begin{array}{l}\text { RCRA past- } \\
\text { practice }\end{array}$ \\
\hline Fuel station & Fuel tank leaks confirmed & Hydrocarbons & Past-practice \\
\hline
\end{tabular}


Table 4.1. (contd)

\begin{tabular}{|c|c|c|c|}
\hline Facility (period of use). & Waste Type & $\begin{array}{l}\text { Constituents of Interest } \\
\text { for Groundwater } \\
\text { Monitoring }\end{array}$ & Type of Site \\
\hline N Reactor basins & Fuel-storage basins & Radionuclides & Inactive \\
\hline $\begin{array}{l}\text { 183-N backwash discharge } \\
\text { pond (1983-present) }\end{array}$ & Filter backwash & None & Active \\
\hline $\begin{array}{l}\text { 124- } \mathrm{N}-10 \text { sewage lagoon } \\
\text { (1987-present) }\end{array}$ & Sanitary waste & Nitrate, coliform & $\begin{array}{l}\text { Active; WAC } \\
\text { permitted }\end{array}$ \\
\hline \multicolumn{4}{|c|}{ 100-D Area } \\
\hline $\begin{array}{l}116-D-7(1944-67) \text { and } \\
116-D R-9(1950-67) \\
\text { retention basins }\end{array}$ & Reactor coolant; leaks known & Radionuclides, chromium & Past-practice \\
\hline $\begin{array}{l}\text { 116-D-1 (1947-67) and } \\
116-\mathrm{DR}-2(1950-67) \\
\text { trenches }\end{array}$ & $\begin{array}{l}\text { Highly radioactive coolant } \\
\text { from fuel-element failure }\end{array}$ & Radionuclides & Past-practice \\
\hline Reactor cribs, drains & $\begin{array}{l}\text { Water and sludges from fuel- } \\
\text { storage basins; decontamina- } \\
\text { tion solutions; condensate } \\
\text { from inert gas system }\end{array}$ & $\begin{array}{l}\text { Carbon-14, nitrate, } \\
\text { strontium-90 }\end{array}$ & Past-practice \\
\hline $\begin{array}{l}\text { Storage tanks and transfer } \\
\text { facilities }\end{array}$ & $\begin{array}{l}\text { Sodium dichromate leakage } \\
\text { from corrosion inhibitor }\end{array}$ & Chromium & Past-practice \\
\hline 120-D-1 ponds (1977-94) & Effluent from water treatment & pH, mercury ${ }^{(\mathrm{b})}$ & $\begin{array}{l}\text { RCRA clean } \\
\text { closed }^{(\ell)}\end{array}$ \\
\hline \multicolumn{4}{|c|}{ 100-H Area } \\
\hline $\begin{array}{l}116-\mathrm{H}-7(107-\mathrm{H}) \text { retention } \\
\text { basin }(1949-65)\end{array}$ & Reactor coolant; leaks known & Tritium, strontium-90 & Past-practice \\
\hline $\begin{array}{l}\text { 116-H-1 (107-H) trench } \\
(1952-65)\end{array}$ & $\begin{array}{l}\text { Highly radioactive coolant } \\
\text { from reactor fuel-element } \\
\text { failure }\end{array}$ & $\begin{array}{l}\text { Tritium, strontium-90, } \\
\text { nitrate }\end{array}$ & Past-practice \\
\hline Reactor cribs, drains & $\begin{array}{l}\text { Water and sludge from fuel- } \\
\text { storage basins; decontamina- } \\
\text { tion solutions }\end{array}$ & Chromium & Past-practice \\
\hline $\begin{array}{l}\text { 183-H solar evaporation } \\
\text { basins (1973-85) }\end{array}$ & Neutralized acid etch solutions & $\begin{array}{l}\text { Technetium-99, uranium, } \\
\text { nitrate, chromium, } \\
\text { fluoride. }\end{array}$ & $\mathrm{RCRA}^{(\mathrm{d})}$ \\
\hline \multicolumn{4}{|c|}{ 100-F Area } \\
\hline $\begin{array}{l}116-\mathrm{F}-14 \text { retention basin } \\
\text { and pipelines }(1945-65)\end{array}$ & Reactor coolant; leaks known & Strontium-90, chromium & Past-practice \\
\hline 116-F-2 trench (1950-65) & Highly radioactive coolant & Strontium-90, chromium & Past-practice \\
\hline 116-F-9 trench $(1963-76)$ & $\begin{array}{l}\text { Cleaning wastes from } \\
\text { experimental animal } \\
\text { laboratories }\end{array}$ & Radionuclides & Past-practice \\
\hline
\end{tabular}


Table 4.1. (contd)

\begin{tabular}{|l|l|l|l|}
\hline \multicolumn{1}{|c|}{ Facility (period of use) } & \multicolumn{1}{|c|}{ Waste Type } & $\begin{array}{l}\text { Constituents of Interest } \\
\text { for Groundwater } \\
\text { Monitoring }\end{array}$ & \multicolumn{1}{|c|}{ Type of Site } \\
\hline $\begin{array}{l}\text { 116-F-3 (1947-51) and } \\
\text { 116-F-6 (1952-65) trenches }\end{array}$ & Reactor coolant and sludge & Radionuclides & Past-practice \\
\hline 116-F-1 trench (1953-65) & $\begin{array}{l}\text { Liquid waste from reactor and } \\
\text { associated buildings }\end{array}$ & $\begin{array}{l}\text { Radionuclides, metals, } \\
\text { uranium, strontium-90, } \\
\text { nitrate }\end{array}$ & Past-practice \\
\hline $\begin{array}{l}\text { 118-F-1 (1954-65) and } \\
\text { 118-F-6 (1965-73) solid } \\
\text { waste-burial grounds }\end{array}$ & $\begin{array}{l}\text { Contaminated equipment, } \\
\text { animal wastes, coal ash }\end{array}$ & Tritium, plutonium & Past-practice \\
\hline $\begin{array}{l}\text { (a) Sites with specific groundwater-monitoring requirements and those that appear to have affected groundwater } \\
\text { quality. }\end{array}$ \\
$\begin{array}{l}\text { (b) Known or suspected in waste; not significantly detected in groundwater to date. } \\
\text { (c) Clean closed in 1999 (no waste left in place). No further RCRA monitoring required. } \\
\text { (d) Groundwater beneath 183-H to be remediated under CERCLA. }\end{array}$ \\
\hline
\end{tabular}

the 100-B,C and 100-F Areas. The K Basins, where spent reactor fuel rods are stored, have leaked in the past and are monitored under DOE Order 5400.1. Monitoring plans for the K Basins, CERCLA, and RCRA are given in Table 4.2 .

The Atomic Energy Act of 1954 and DOE Order 5400.1 also require sitewide surveillance monitoring to track contaminant plumes. Wells monitored for those requirements in 1996 were listed by Bisping (1996).

\subsection{Conceptual Model}

The most widespread contaminants of concern in 100 Areas' groundwater are tritium, nitrate, and hexavalent chromium. Groundwater is locally contaminated with strontium-90, carbon-14, technetium-99, uranium, trichloroethylene, and sulfate. Groundwater also flows into the 100 Areas through the gap between Gable Mountain and Gable Butte, carrying contamination from the 200 Areas.

Contaminated effluent has been reaching the soil in the 100 Areas for $\sim 50$ years from leaking retention basins and disposal trenches. Radionuclides with short half-lives decayed in the retention basins or in the vadose zone. Nonradioactive constituents and longer-lived radionuclides were carried down through the vadose zone beneath the waste sites. Some of these sorbed to sediments, some remained in the moisture in the vadose zone, and large quantities were carried into the groundwater (Figure 4.1). 
Table 4.2. Groundwater Monitoring in the 100 Areas

\begin{tabular}{|c|c|}
\hline $\begin{array}{l}\text { Monitoring Requirement } \\
\text { (monitoring plan reference) }\end{array}$ & Comments \\
\hline \multicolumn{2}{|c|}{ 100-B,C Area } \\
\hline $\begin{array}{l}\text { CERCLA (Federal Facility Agreement and Consent } \\
\text { Order Change Control Form M-15-96-07) }\end{array}$ & Long-term plume monitoring \\
\hline \multicolumn{2}{|c|}{ 100-K Area } \\
\hline CERLCA (ROD 1996a, DOE 1996a) & $\begin{array}{l}\text { CERCLA interim action for chromium; wells near } \\
116-\mathrm{K}-2 \text { trench }^{(\mathrm{a})}\end{array}$ \\
\hline $\begin{array}{l}\text { CERCLA (National Priorities List Change Control } \\
\text { Form 108, 11/20/96) }\end{array}$ & $100-\mathrm{KR}-4$ Operable Unit remedial investigation \\
\hline DOE Order 5400.1 (Johnson et al. 1995) & $\mathrm{KE}$ and $\mathrm{KW}$ fuel-storage basins \\
\hline \multicolumn{2}{|c|}{ 100-N Area } \\
\hline RCRA (Hartman 1996) & 1301-N, 1324-N/NA, 1325-N sites \\
\hline $\begin{array}{l}\text { CERCLA (National Priorities List Change Control } \\
\text { Form } 113,3 / 25 / 97 \text { ) }\end{array}$ & $\begin{array}{l}\text { N springs expedited response action (strontium-90 plume } \\
\text { near } 1301-N)^{(\lambda)}\end{array}$ \\
\hline $\begin{array}{l}\text { CERCLA (Federal Facility Agreement and Consent } \\
\text { Order Change Control Form M-15-96-08, 10/9/96; } \\
\text { Borghese et al. 1996) }\end{array}$ & $\begin{array}{l}\text { 100-NR-2 Operable Unit remedial investigation; also } \\
\text { includes RCRA wells of Hartman (1996) }\end{array}$ \\
\hline $\begin{array}{l}\text { National Pollutant Discharge Elimination System } \\
\text { Permit WA-000374-3 }\end{array}$ & Well 199-N-8T \\
\hline \multicolumn{2}{|c|}{ 100-D Area } \\
\hline CERCLA (ROD 1996a, DOE 1996a) & $\begin{array}{l}\text { CERCLA interim action for chromium; wells near retention } \\
\text { basins and disposal trenches }{ }^{(2)}\end{array}$ \\
\hline $\begin{array}{l}\text { CERCLA (National Priorities List Change Control } \\
\text { Form } 107,11 / 20 / 96 \text { ) }\end{array}$ & 100-HR-3 (D Area) Operable Unit remedial investigation \\
\hline \multicolumn{2}{|c|}{ 100-H Area } \\
\hline RCRA (Hartman 1997) & 183-H solar evaporation basins \\
\hline CERCLA (ROD 1996a, DOE 1996a) & CERCLA interim action for chromium ${ }^{(\mathbf{l})}$ \\
\hline $\begin{array}{l}\text { CERLCA (Peterson and Raidl 1996; National } \\
\text { Priorities List Change Control Form 107, 11/20/96) }\end{array}$ & $\begin{array}{l}\text { 100-HR-3 (H Area) Operable Unit remedial investigation } \\
\text {. }\end{array}$ \\
\hline \multicolumn{2}{|c|}{ 100-F Area } \\
\hline $\begin{array}{l}\text { CERLCA (Federal Facility Agreement and Consent } \\
\text { Order Change Control Form M-15-96-06) }\end{array}$ & Long-term plume monitoring \\
\hline
\end{tabular}




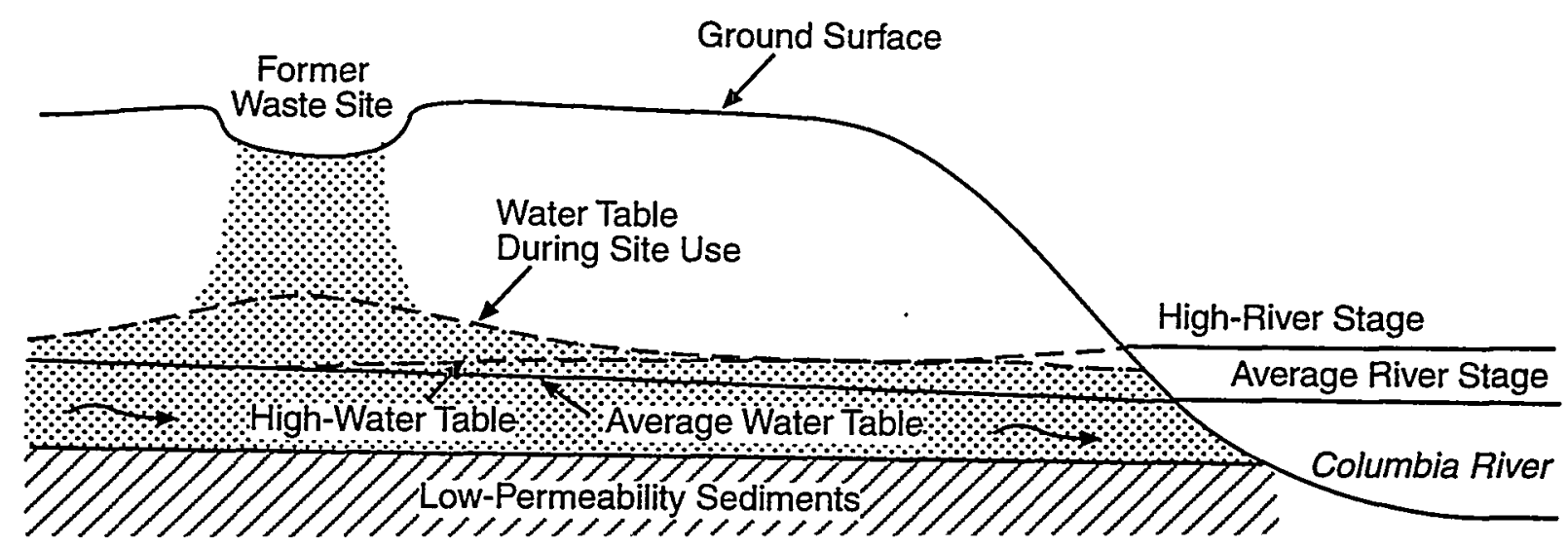

Contaminants

$\longrightarrow$ Direction of Groundwater Flow

Not to Scale

RG980900050.1

Figure 4.1. Conceptual Model of Subsurface Contamination in the 100 Areas

When the reactors were active, huge volumes of water were discharged, creating large groundwater mounds that disrupted the natural groundwater-flow patterns. The contaminants moved outward on these mounds, contaminating a larger area in the saturated zone than in the vadose zone. The mounds dissipated after discharges ceased, and groundwater flow resumed its normal pattern (i.e., toward the river). Groundwater beneath the 100 Areas continues to carry contaminants to the river, where it discharges from springs, seeps, and through the riverbed below the water line. Groundwater nearest the river often has lower concentrations of contaminants because of dilution. When river stage is high, the water table may rise into the former mound areas and mobilize some constituents (see Figure 4.1) or it may dilute contaminants further. This influx of river water.also temporarily disrupts the direction and rate of groundwater flow. Locally, groundwater extraction and injection also affect flow directions and intercept contaminants before they reach the river.

The vertical component of groundwater flow in the 100 Areas is generally upward, and most of the contamination is limited to the unconfined aquifer. However, it is likely that when groundwater mounds were present, there was a significant downward gradient, and several wells that monitor the confined Ringold or basalt-confined aquifers appear to be contaminated.

Contaminant concentrations are expected to decrease with time because of dispersion, dilution, radioactive decay, remediation, and discharge to the river. There are no new sources of contamination, but concentrations will vary because of plume movement and mobilization of vadose zone contamination. 


\subsection{Monitoring Program}

Locations of monitoring wells for the 100 Areas are illustrated in Figures 4.2 through 4.8 and are listed in Appendix A. In addition to the shallow unconfined wells, the network includes most of the few available deeper wells (completed in the confined Ringold or the basalt-confined aquifer). Most of the 600 Area wells will be sampled every 3 years. Wells in the reactor areas are sampled every year, except for those wells near the river or wells with highly variable concentrations that are sampled more frequently. Wells monitoring the in situ redox manipulation application in the 100-D Area are monitored quarterly. 


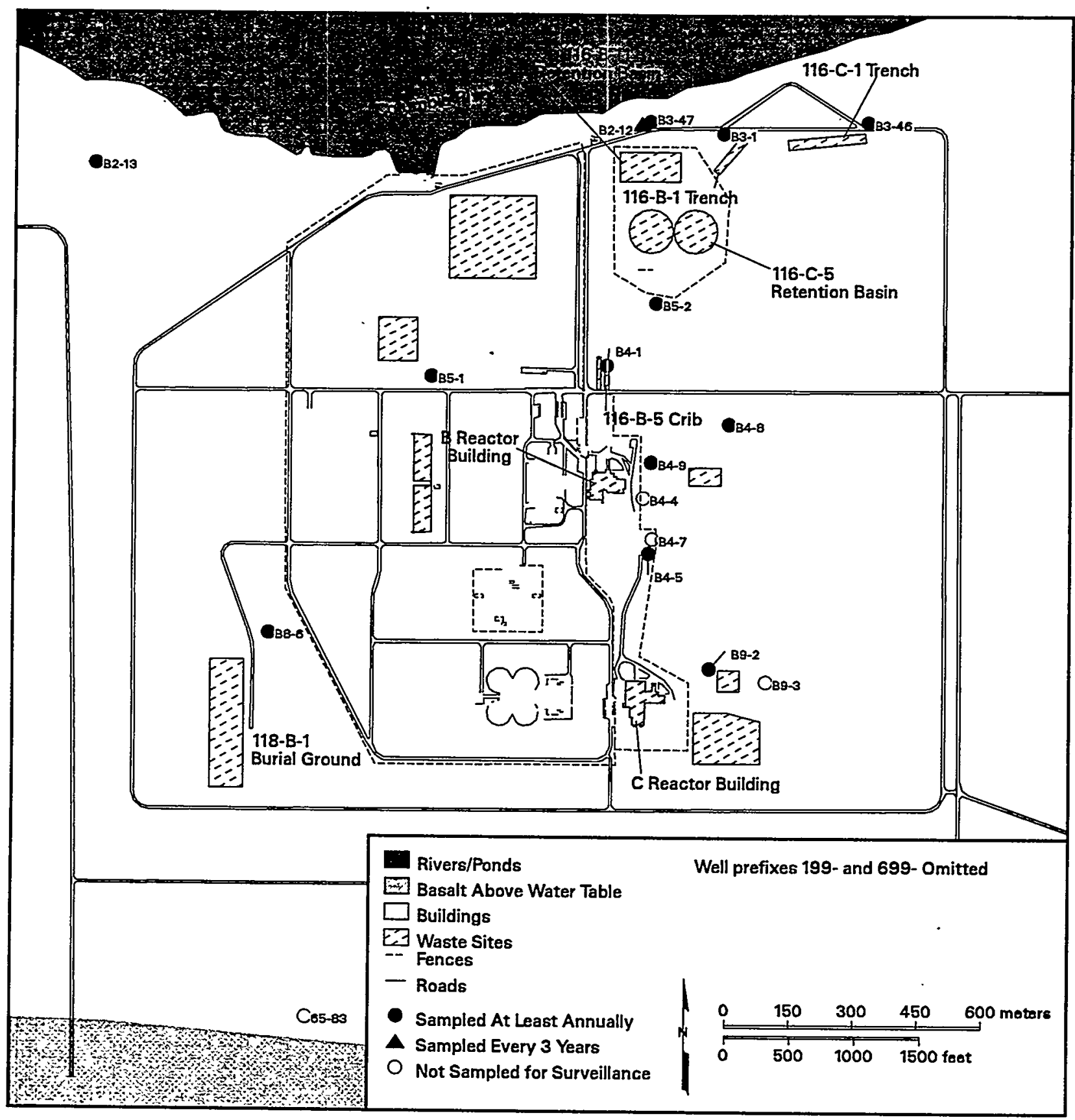

can_hart_s9009 Soptember 21, 1999 12:07 PM

Figure 4.2. Groundwater Project Well Locations: 100-B,C Area 


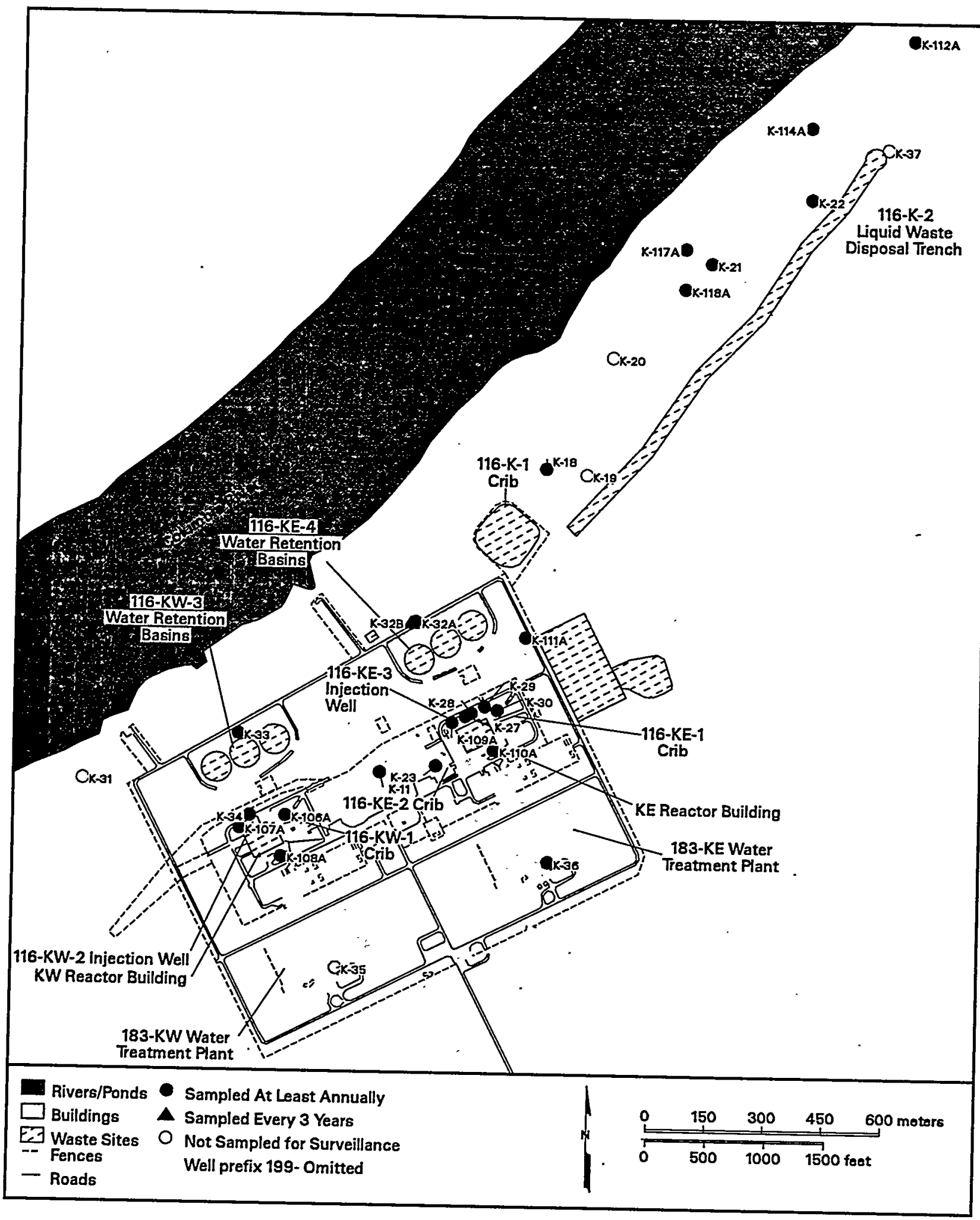

can_hart_99010 Septomber 20, 1999 1:45 PM

Figure 4.3. Groundwater Project Well Locations: 100-K Area 


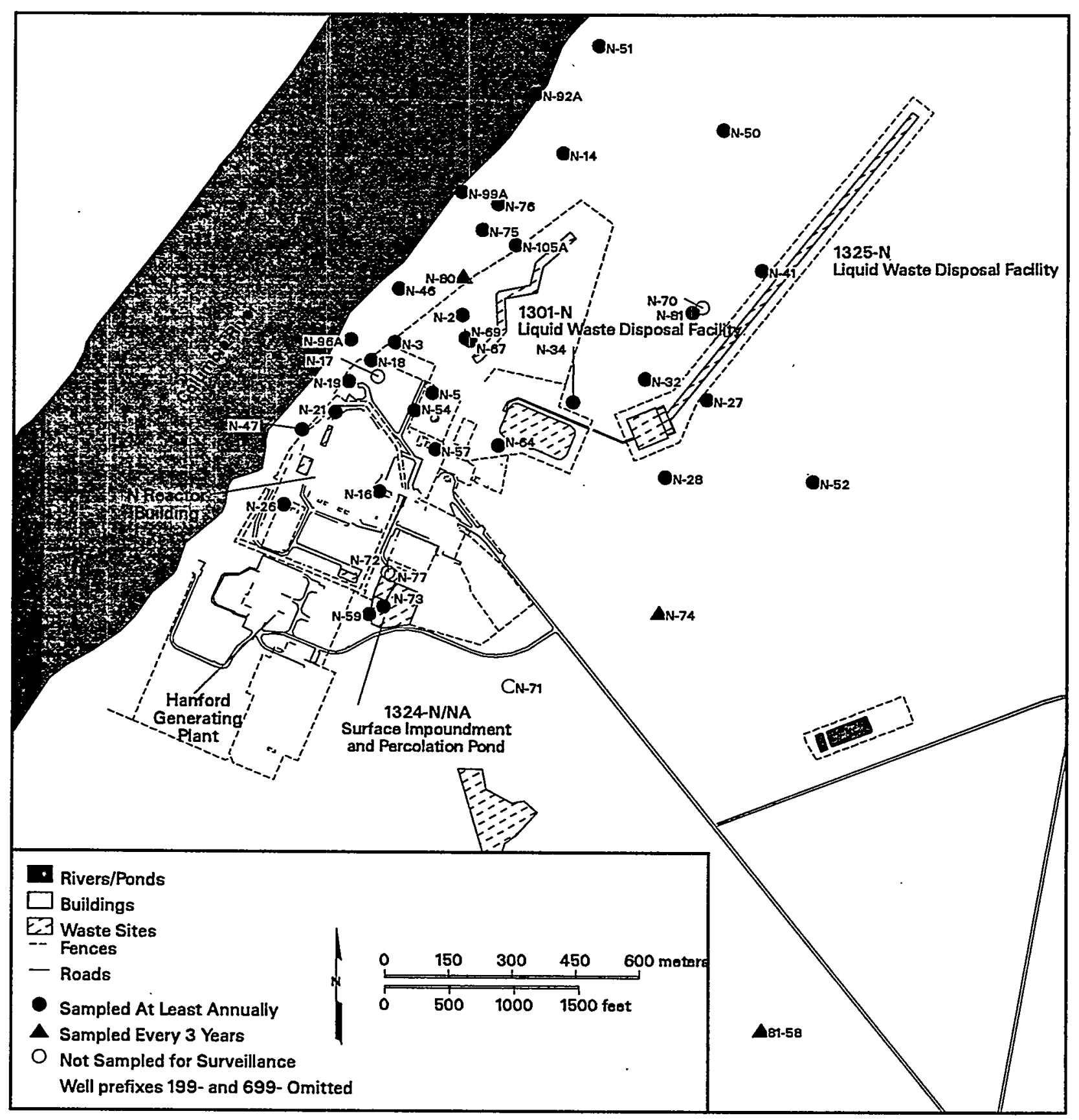

can_hart_9s011 September 21, 1999 12:42 PM

Figure 4.4. Groundwater Project Well Locations: $100-\mathrm{N}$ Area 


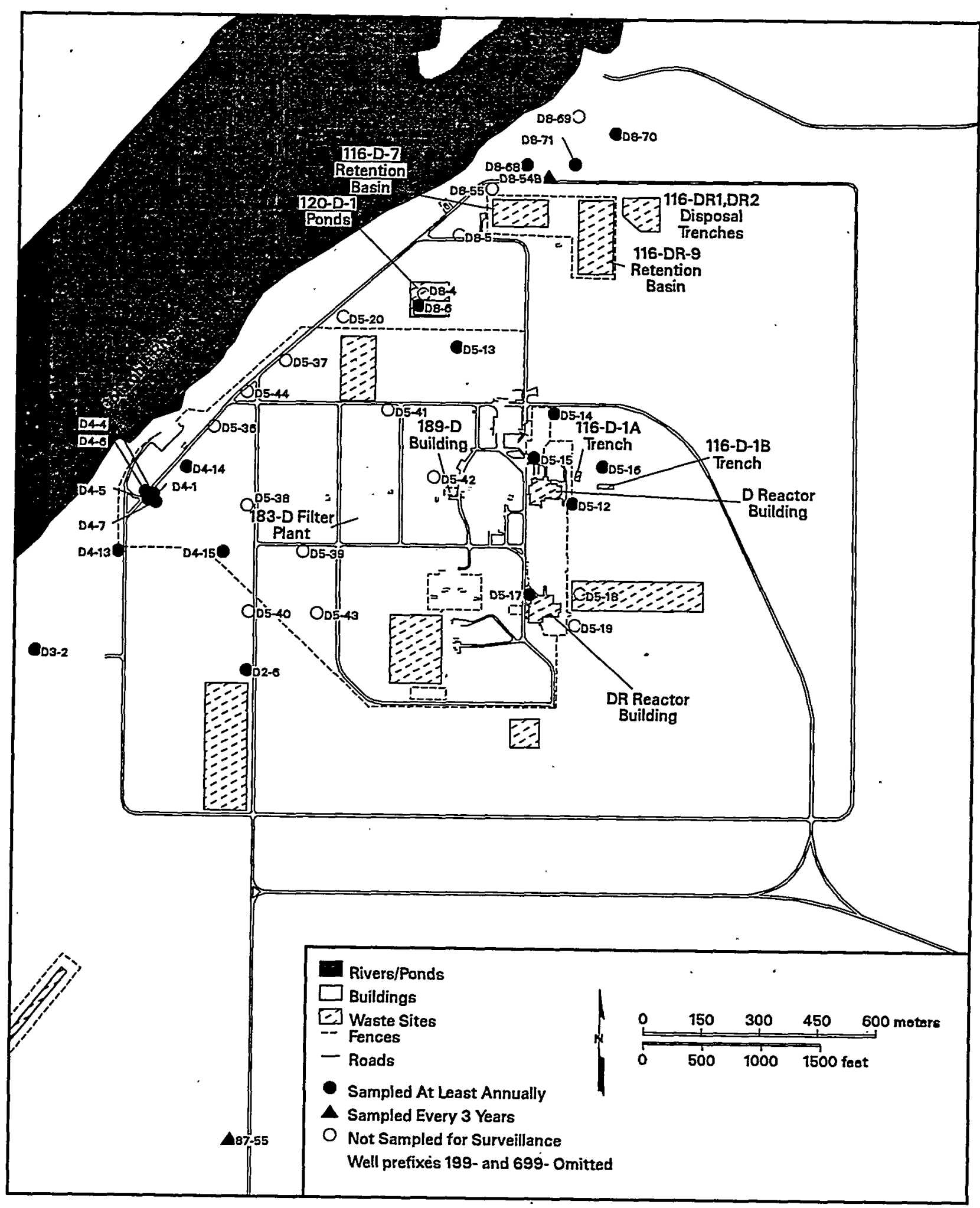

can_hart_99012 Septomber 22,1999 12:00 PM

Figure 4.5. Groundwater Project Well Locations: 100-D Area 


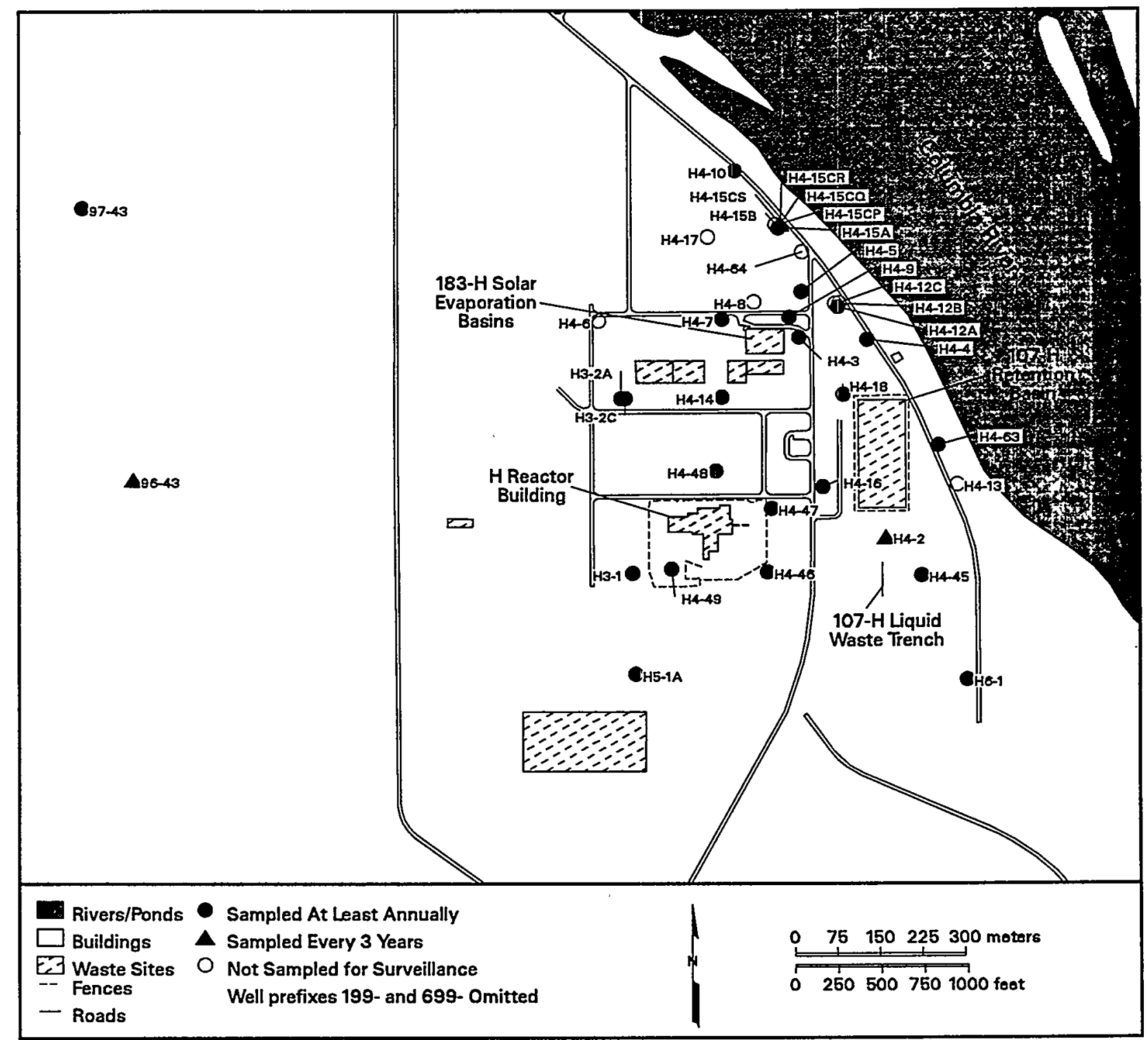

can_hart_99013 Soptomber 21, 1999 12:47 PM

Figure 4.6. Groundwater Project Well Locations: 100-H Area 


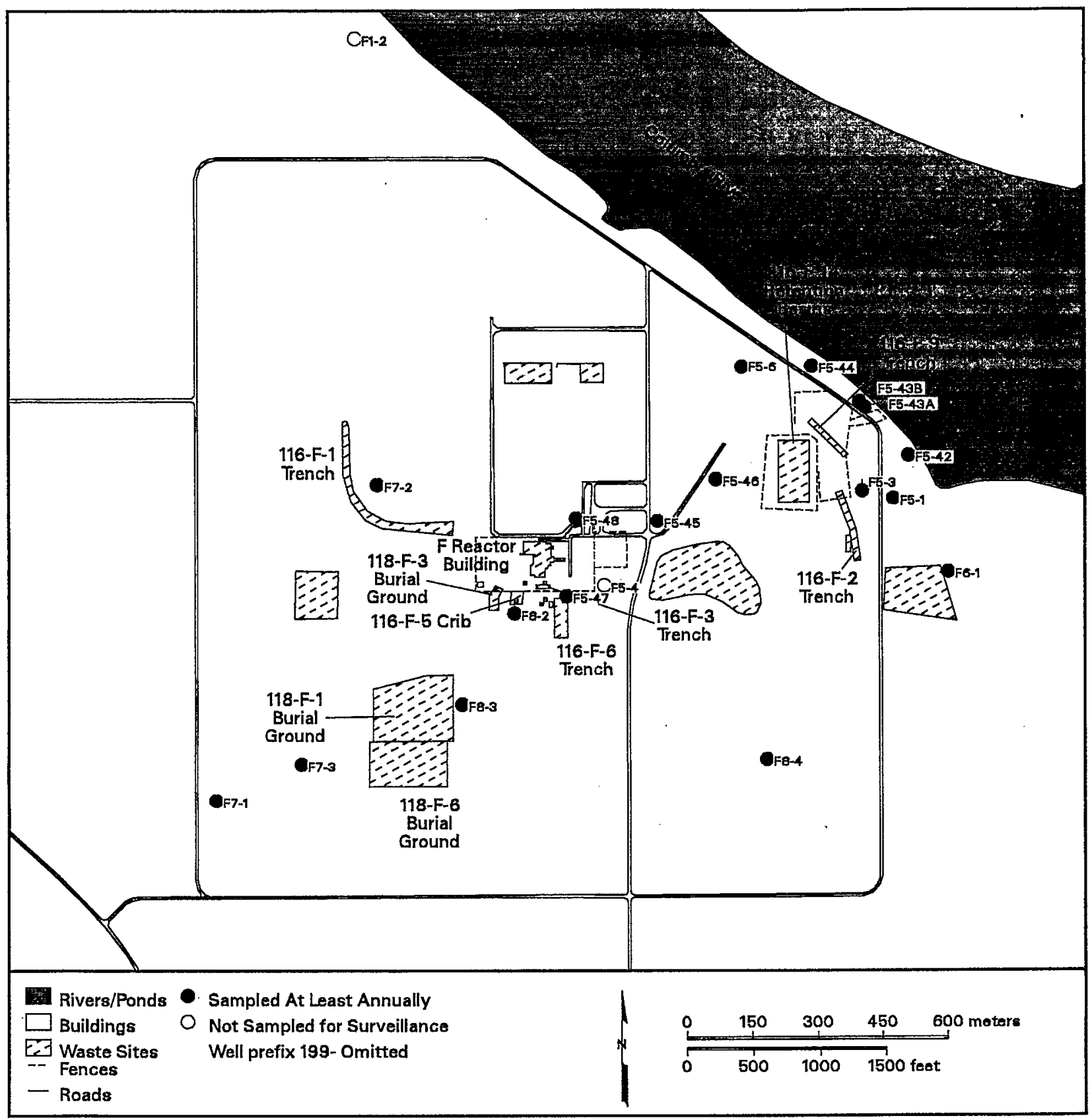

can_hart_99014 Soptembar 21, 1989 1:19 PM

Figure 4.7. Groundwater Project Well Locations: $100-F$ Area 


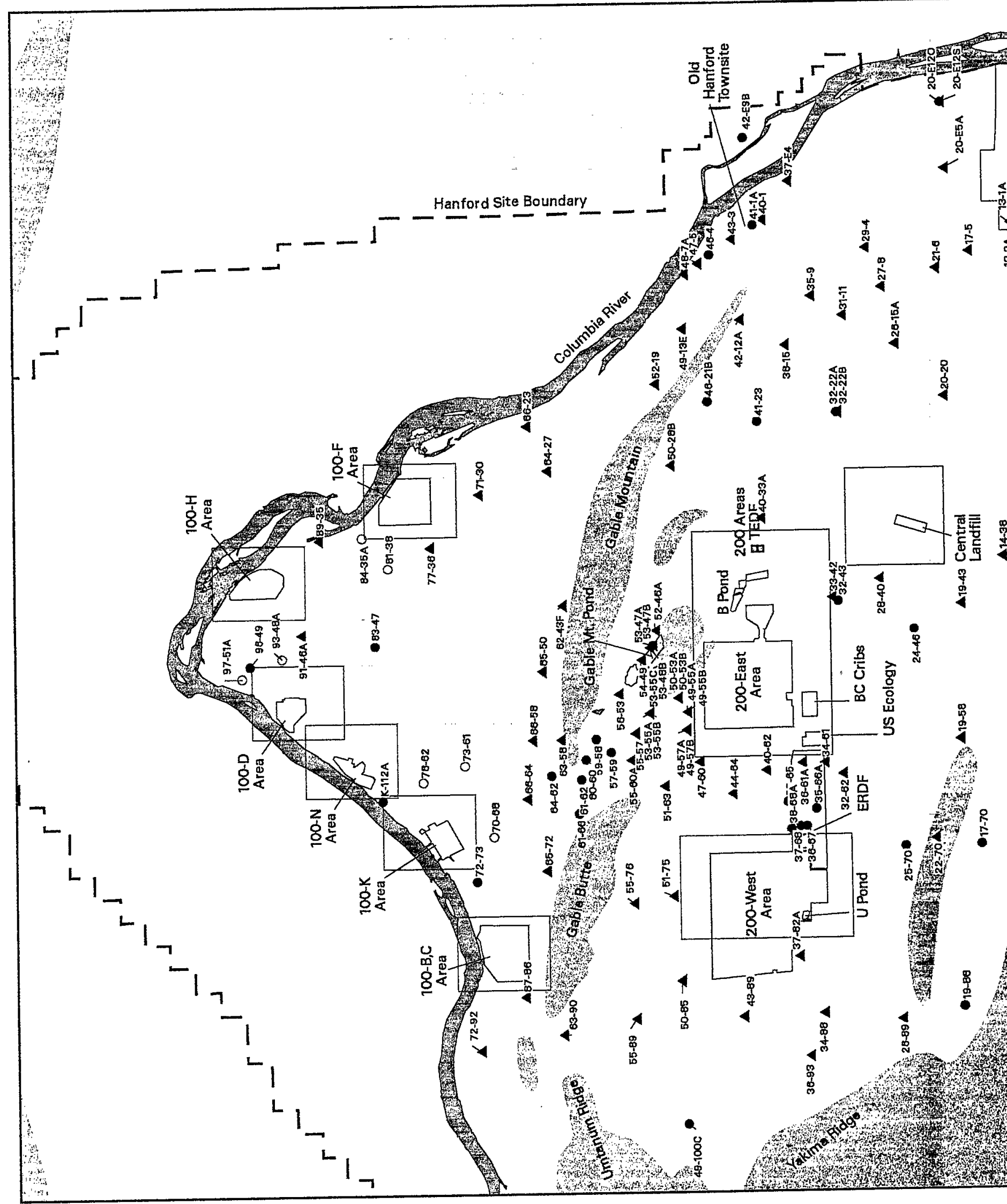




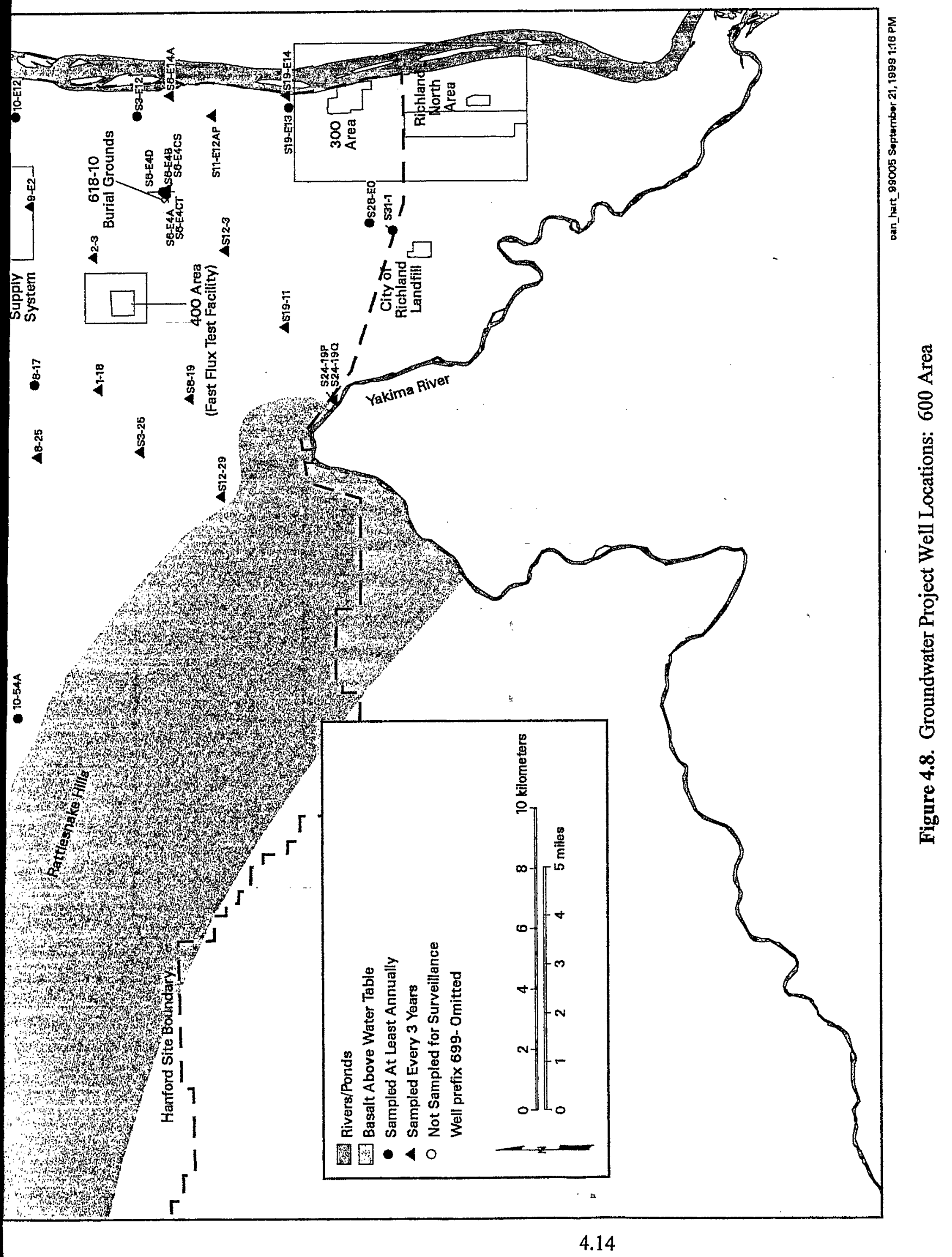




\section{$5.0 \quad$ 200-West Area}

The 200-West Area is located on the central plateau of the Hanford Site. Portions of the 600 Area affected by groundwater contamination originating in or near the 200 -West Area were evaluated for the monitoring network in this chapter.

\subsection{Background}

Activities within this area have included irradiated nuclear fuel processing and liquid and solid waste storage and disposal. This area has been used since the 1940s.

\subsubsection{Waste Sites, Discharges, and Groundwater Operable Units}

Several processing facilities in the 200-West Area have contributed to groundwater contamination through disposal of radioactive and hazardous liquid wastes in ponds, cribs, ditches, and underground storage tanks. Large quantities of solid wastes, both from on and off the site, have been disposed of in numerous burial grounds in the 200-West Area. The major sites are listed in Table 5.1. Additional information is provided in Hartman and Dresel (1998), and more complete site inventories are included in reports listed in the bibliography of that document. A number of facilities are regulated under RCRA because they were more recently active and contain, or contained, dangerous chemical waste constituents. Six RCRA units have groundwater-monitoring requirements, including two low-level burial grounds, which are the only sites actively receiving waste within the 200-West Area. Four single-shell tank waste management areas located in the 200-West Area also are monitored under RCRA; the tanks currently are used to store mixed waste. The 616-A Crib, also known as the State-Approved Land-Disposal Site, is located just north of the 200-West Area. The site consists of a drain field that is used to dispose of liquid waste containing tritium.

Two CERCLA groundwater operable units relate to 200-West Area contamination. The 200-UP-1 Operable Unit generally covers the groundwater in the southeastern part of the area, where technetium-99 and uranium contamination near U Plant are being remediated by a CERCLA interim action. The 200-ZP-1 Operable Unit generally covers groundwater contamination originating in the northwestern part of the 200-West Area, where interim actions are in place to remediate carbon tetrachloride contamination.

\subsubsection{Groundwater-Monitoring Requirements and History}

Groundwater-monitoring wells in the 200-West Area were installed to monitor specific disposal facilities in the mid 1940s. RCRA monitoring wells were installed beginning in 1987. Several injection and extraction wells have been drilled to support interim-action pump-and-treat systems.

The Atomic Energy Act of 1954 and DOE Order 5400.1 require monitoring to identify and track contaminant plumes. Wells monitored for those requirements in 1996 were listed by Bisping (1996). 
Table 5.1. Selected Waste Sites in the 200-West Area ${ }^{(a)}$

\begin{tabular}{|c|c|c|c|}
\hline Facility & Waste Type & $\begin{array}{l}\text { Constituents of Interest } \\
\text { for Groundwater } \\
\text { Monitoring }\end{array}$ & $\begin{array}{c}\text { Type of Site } \\
\text { (monitoring plan } \\
\text { reference) }\end{array}$ \\
\hline $\begin{array}{l}\text { Single-shell tank farms } \\
\text { (Waste Management } \\
\text { Areas S-SX, T, TX-TY, } \\
\text { and U) }\end{array}$ & $\begin{array}{l}\text { Radioactive/chemical } \\
\text { slurries }\end{array}$ & $\begin{array}{l}\text { Sodium hydroxide, } \\
\text { sodium salts, radionu- } \\
\text { clides, ferrocyanide }\end{array}$ & $\begin{array}{l}\text { RCRA (Caggiano 1996a, } \\
\text { Caggiano and Goodwin } \\
\text { 1991, Caggiano and } \\
\text { Chou 1993) }\end{array}$ \\
\hline $\begin{array}{l}\text { T Plant cribs (216-T-26, } \\
-28,-19) \text { and } \\
216-\mathrm{T}-25 \text { trench }\end{array}$ & $\begin{array}{l}\text { Diverse chemical and } \\
\text { radiological waste }\end{array}$ & $\begin{array}{l}\text { Tritium, iodine-129, } \\
\text { technetium-99, nitrate, } \\
\text { chromium, carbon tetra- } \\
\text { chloride, chloroform, } \\
\text { trichloroethylene, } \\
\text { fluoride }\end{array}$ & Past-practice \\
\hline $\begin{array}{l}\text { Reduction-Oxidation } \\
\text { Plant disposal facilities } \\
\text { (including 216-S-10 } \\
\text { pond/ditch) }\end{array}$ & $\begin{array}{l}\text { Solvent-extraction } \\
\text { process wastes }\end{array}$ & $\begin{array}{l}\text { Nitrate, trichloroethyl- } \\
\text { ene, tritium, iodine-129, } \\
\text { technetium-99, uranium }\end{array}$ & $\begin{array}{l}\text { Past-practice, except } \\
\text { S-10: RCRA (Airhart } \\
\text { et al. 1990) }\end{array}$ \\
\hline $\begin{array}{l}\text { U Plant disposal } \\
\text { facilities (216-U- } 12 \text { and } \\
\text { other retention trenches) }\end{array}$ & $\begin{array}{l}\text { Supernatant from } \\
\text { scavenged waste }\end{array}$ & $\begin{array}{l}\text { Iodine-129, } \\
\text { technetium-99, uranium, } \\
\text { nitrate, trichloroethylene }\end{array}$ & $\begin{array}{l}\text { Past-practice, except } \\
\text { U-12: RCRA (Jensen } \\
\text { et al. 1990, Williams and } \\
\text { Chou 1993). 200-UP-1 } \\
\text { interim action (DOE } \\
\text { 1996b, ROD 1997) }\end{array}$ \\
\hline $\begin{array}{l}\text { Plutonium Finishing } \\
\text { Plant cribs (216-Z-1A } \\
\text { and -Z-9) }\end{array}$ & $\begin{array}{l}\text { Transuranic and } \\
\text { chemical wastes }\end{array}$ & $\begin{array}{l}\text { Nitrate, carbon tetra- } \\
\text { chloride, chloroform, } \\
\text { trichloroethylene }\end{array}$ & $\begin{array}{l}\text { Past-practice 200-ZP-1 } \\
\text { interim action (Freeman- } \\
\text { Pollard 1996) }\end{array}$ \\
\hline $\begin{array}{l}\text { Low-level burial grounds } \\
\text { (Waste Management } \\
\text { Areas } 3 \text { and 4) }\end{array}$ & Radioactive solid waste & $\begin{array}{l}\text { Various chemical and } \\
\text { radioactive wastes }(c)\end{array}$ & $\begin{array}{l}\text { RCRA (Last and } \\
\text { Bjornstad 1989) }\end{array}$ \\
\hline $\begin{array}{l}\text { 616A Crib (State- } \\
\text { Approved Land- } \\
\text { Disposal Site) }\end{array}$ & Treated liquid effluent & Tritium & $\begin{array}{l}\text { Active; WAC permitted } \\
\text { (Davis et al. 1996) }^{(b)}\end{array}$ \\
\hline $\begin{array}{l}\text { Environmental } \\
\text { Restoration Disposal } \\
\text { Facility }\end{array}$ & $\begin{array}{l}\text { Excavated, contami- } \\
\text { nated soil and debris } \\
\text { (potentially radioactive } \\
\text { and/or hazardous) }\end{array}$ & $\begin{array}{l}\text { Nonie anticipated } \\
\text { (double-lined facility) }\end{array}$ & $\begin{array}{l}\text { Active (Weeks et al. } \\
\text { 1996, Ford 1996) }\end{array}$ \\
\hline \multicolumn{4}{|c|}{$\begin{array}{l}\text { (a) Sites with specific groundwater-monitoring requirements and those that appear to have affected } \\
\text { groundwater quality. } \\
\text { (b) Groundwater monitored independently of groundwater project. } \\
\text { (c) Present in waste; not found in groundwater. }\end{array}$} \\
\hline
\end{tabular}




\subsection{Conceptual Model}

The most widespread hazardous chemical contaminants of concern in 200-West Area groundwater are nitrate, carbon tetrachloride, and chloroform. Smailer plumes of chromium and trichloroethylene are also present. Technetium-99, uranium, tritium, and iodine-129 are the most significant radionuclides in groundwater.

Contaminated effluent has reached the soil from cribs, trenches, tile fields, surface impoundments, and leaking tanks associated with T Plant, Reduction-Oxidation Plant, U Plant, and Plutonium Finishing Plant. Radionuclides with short half-lives decayed in the vadose zone, while nonradioactive constituents and longer-lived radionuclides were carried deeper. Some of these sorbed to sediments; some remained in the moisture in the vadose zone, and large quantities were carried into the groundwater.

The groundwater-flow direction beneath the southern portion of the 200-West Area is to the east. Groundwater flows to the northeast beneath the northern part of the area. In the past, waste-disposal practices created groundwater mounds that caused some westward flow of contaminants. Contaminants moved outward from these mounds, contaminating a larger area in the saturated zone than in the vadose zone. These mounds are still present but are declining, and the most recent information indicates that the westward flow has ceased. Interim remedial action systems, where groundwater is extracted, treated, and reinjected, locally perturb groundwater-flow directions near the Plutonium Finishing Plant and east of U Plant.

The few shallow and deep well pairs indicate that the vertical flow gradient is downward in the 200-West Area. Contamination in the deeper parts of the unconfined aquifer appear to be considerably less than in the upper portion of the aquifer. It should be noted, however, that very few wells monitor the deeper portions of the aquifer, and at some locations certain contaminants are found at greater concentrations at depth.

Contaminant concentrations are expected to decrease with time because of dispersion, dilution, radioactive decay, remediation, and migration. There are no new sources of contamination, but concentrations will vary because of plume movement and mobilization of vadose zone contamination.

\subsection{Monitoring Program}

The primary objective of the surveillance monitoring program in the 200-West Area is to monitor the extent of plumes emanating from 200-West Area waste sites. Most of the sites have ceased operation, and many wells monitoring the widespread plumes will be sampled every 3 years to track the rate of migration and attenuation. Other wells will be sampled annually or more frequently.

Another objective of surveillance monitoring is to address hazardous waste sites that ceased operation before 1985 and radioactive waste sites, which are not regulated by RCRA. Wells are monitored near the most significant sources to see if contaminants are declining as expected and to detect contaminants migrating from the vadose zone. These wells are monitored annually or more frequently.

The locations of the monitoring wells in the 200-West Area are illustrated in Figure 5.1 (600 Area wells were shown in Figure 4.8). Wells and constituents are listed in Appendix A. 


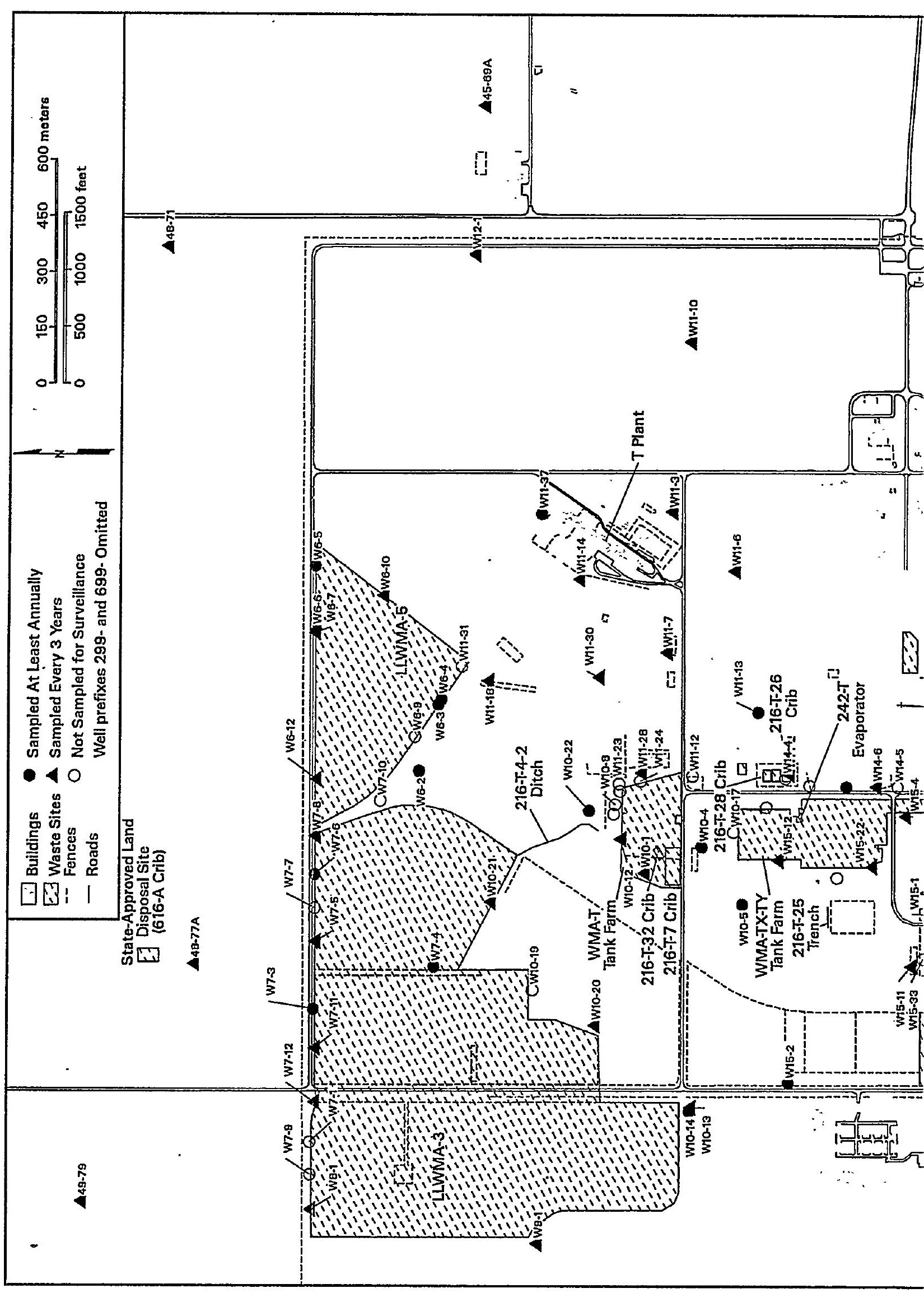




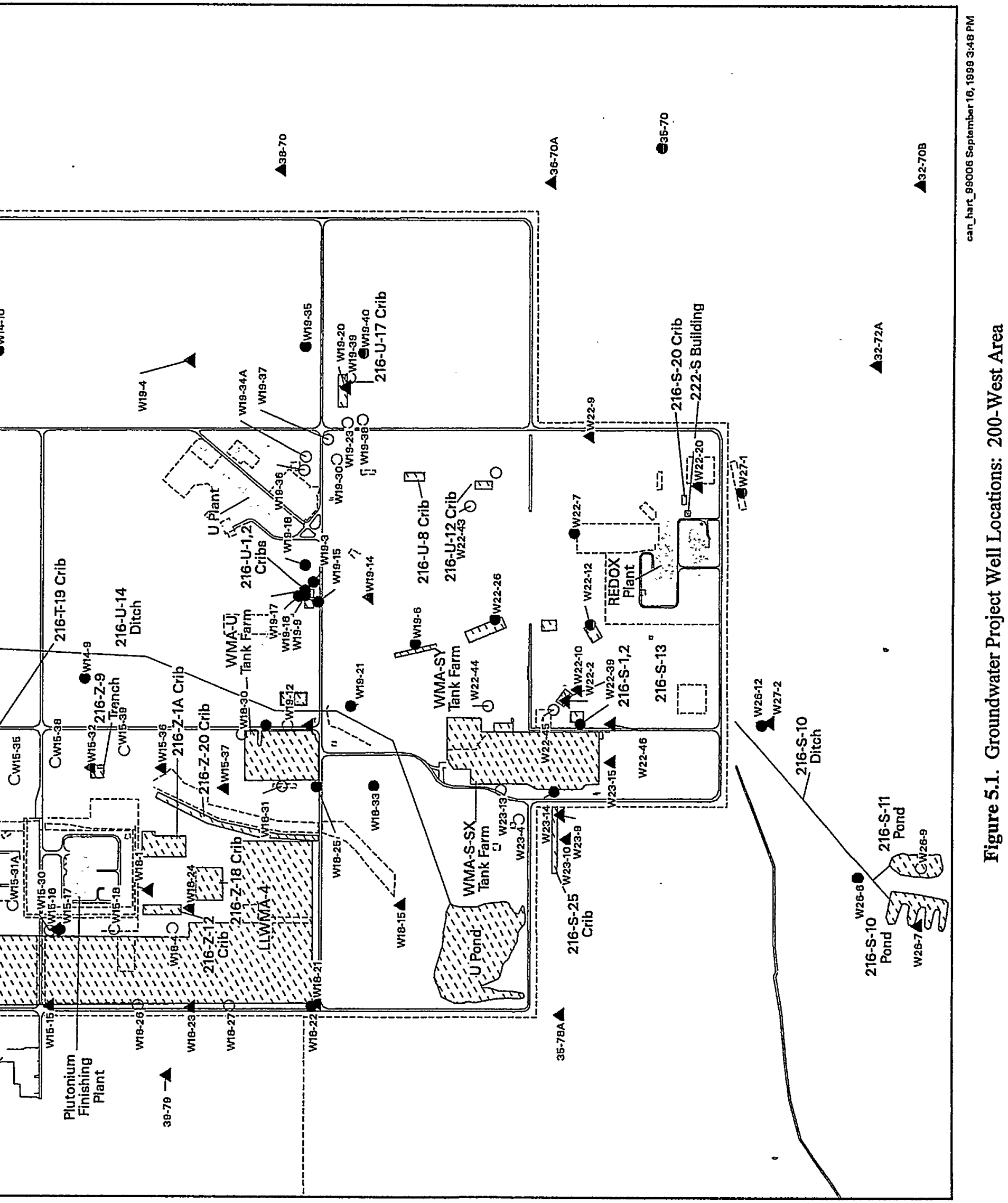




\subsection{0-East Area}

For the purposes of this plan, "200-East Area" describes that portion of the Hanford Site within the 200-East Area fence line, those parts of the site downgradient from the area that shows impacts by contaminants originating in the 200-East Area, and those disposal facilities outside the fence line but associated with 200-East Area operations. Thus, B Pond, Gable Mountain Pond, and BC Cribs will be included in the following discussion. The 200 Areas Treated Effluent-Disposal Facility also falls generally within this part of the site but is monitored under the specific requirements of its state wastedischarge permit.

\subsection{Background}

\subsubsection{Waste Sites, Discharges, and Groundwater Operable Units}

Hundreds of waste sites have been identified in the 200-East Area, including radioactive and mixed waste-storage tanks; low-level burial grounds; effluent disposal cribs, ditches, drains, and ponds; and various spills or other unplanned releases. The major sites are listed in Table 6.1. Additional information is provided in Hartman and Dresel (1998), and more complete site inventories are included in reports listed in the bibliography of that document. A number of facilities are regulated under RCRA because they were more recently active and contain, or contained, dangerous waste constituents. Several of the RCRA units have groundwater-monitoring requirements and are included in Table 6.1.

The 200 Areas Treated Effluent-Disposal Facility, located east of the 200-East Area proper, is the only active liquid-disposal facility in the area. As mentioned above, this is monitored under a state wastedischarge permit. The permitted discharge does not include radioactive or hazardous constituents. LowLevel Waste Management Areas 1 and 2 are burial grounds regulated under RCRA, which continue to receive radioactive solid waste. Three single-shell tank waste management areas, also regulated under RCRA, no longer actively receive waste but currently store mixed waste.

Groundwater in the northwestern part of the 200-East Area forms the 200-BP-5 Operable Unit, while the southeastern part of the site is in the 200-PO-1 Operable Unit. 200-BP-5 remediation is being performed under CERCLA regulations, while 200-PO-1 is being remediated under RCRA regulations (although requirements of both sets of regulations are considered in the cleanup process). Two groundwater-extraction treatability tests were performed in the 200-BP-5 Operable Unit - the first near the 216-B-5 injection well and the second just north of the northwestern corner of the 200-East Area in an area of contamination originating in the BY Cribs. There is no active groundwater remediation in the 200-East Area. The interim action recommended in the Hanford Sitewide Groundwater Remediation Strategy (DOE 1995a) is natural attenuation and decay of contaminant plumes. There is, however, no interim or final ROD for the operable units in the 200-East Area. 
Table 6.1. Selected Waste Sites in and Downgradient of the 200-East Area

\begin{tabular}{|c|c|c|c|}
\hline Facility (period of use) & Waste Type & $\begin{array}{l}\text { Constituents of Interest } \\
\text { for Groundwater } \\
\text { Monitoring }\end{array}$ & $\begin{array}{l}\text { Type of Site } \\
\text { (monitoring plan } \\
\text { reference) }\end{array}$ \\
\hline \multicolumn{4}{|c|}{ 200-East Area Proper and Adjacent Facilities } \\
\hline $\begin{array}{l}\text { Single-shell tank farms } \\
\text { (Waste Management } \\
\text { Areas A-AX, B-BX-BY, } \\
\text { C) }\end{array}$ & $\begin{array}{l}\text { Radioactive/chemical } \\
\text { slurries }\end{array}$ & $\begin{array}{l}\text { Sodium hydroxide, } \\
\text { sodium salts, radionu- } \\
\text { clides, ferrocyanide }\end{array}$ & $\begin{array}{l}\text { RCRA (Caggiano and } \\
\text { Goodwin 1991, } \\
\text { Caggiano 1996b) }\end{array}$ \\
\hline $216-\mathrm{B}-7 \mathrm{~A},-7 \mathrm{~B},-8 \mathrm{cribs}$ & $\begin{array}{l}\text { Supernatant from } \\
\text { settling tanks }\end{array}$ & $\begin{array}{l}\text { Sodium hydroxide, } \\
\text { sodium salts, radionu- } \\
\text { clides, ferrocyanide }\end{array}$ & $\begin{array}{l}\text { Past-practice (200-BP-5 } \\
\text { Operable Unit; DOE } \\
\text { 1995b) }\end{array}$ \\
\hline 216-B-37 trench & $\begin{array}{l}\text { Concentrated waste } \\
\text { from tank bottoms }\end{array}$ & $\begin{array}{l}\text { Sodium hydroxide, } \\
\text { sodium salts, radionu- } \\
\text { clides, ferrocyanide }\end{array}$ & $\begin{array}{l}\text { Past-practice (200-BP-5 } \\
\text { Operable Unit; DOE } \\
\text { 1995b) }\end{array}$ \\
\hline $\begin{array}{l}\text { 216-B-5 injection well } \\
(1945-46)\end{array}$ & $\begin{array}{l}\text { Hot cell drainage; } \\
\text { supernatant from } \\
\text { settling tanks }\end{array}$ & $\begin{array}{l}\text { Strontium-90, } \\
\text { cesium-137, plutonium }\end{array}$ & $\begin{array}{l}\text { Past-practice (200-BP-5 } \\
\text { Operable Unit; DOE } \\
\text { 1995b) }\end{array}$ \\
\hline $\begin{array}{l}\text { BY cribs and trench } \\
(1954-55)\end{array}$ & $\begin{array}{l}\text { Uranium-recovery waste } \\
\text { supernatant }\end{array}$ & $\begin{array}{l}\text { Ferrocyanide, } \\
\text { radionuclides }\end{array}$ & $\begin{array}{l}\text { Past-practice (200-BP-5 } \\
\text { Operable Unit; DOE } \\
\text { 1995b) }\end{array}$ \\
\hline $\begin{array}{l}\text { 216-B-63 trench } \\
(1970-92)\end{array}$ & Steam condensate & $\begin{array}{l}\text { Sulfuric acid, sodium } \\
\text { hydroxide, radionuclides }\end{array}$ & RCRA (Sweeney 1995a) \\
\hline $\begin{array}{l}\text { Plutonium-Uranium } \\
\text { Extraction Plant waste- } \\
\text { disposal cribs }\end{array}$ & Process distillate & $\begin{array}{l}\text { Radionuclides } \\
\text { (especially tritium, } \\
\text { iodine-129), nitrate }\end{array}$ & $\begin{array}{l}\text { 216-A-10, -36B, -37-1: } \\
\text { RCRA (Lindberg 1997); } \\
\text { others: past-practice } \\
\text { (200-PO-1 Operable } \\
\text { Unit; DOE 1996c) }\end{array}$ \\
\hline 216-A-29 ditch & $\begin{array}{l}\text { Plutonium-Uranium } \\
\text { Extraction Plant chemi- } \\
\text { cal waste }\end{array}$ & $\begin{array}{l}\text { Sodium hydroxide, } \\
\text { sulfuric acid }\end{array}$ & $\begin{array}{l}\text { RCRA (Kasza and } \\
\text { Goodwin 1991) }\end{array}$ \\
\hline 216-B-3 pond & $\begin{array}{l}\text { B Plant steam conden- } \\
\text { sate and chemical waste; } \\
\text { Plutonium-Uranium } \\
\text { Extraction Plant chemi- } \\
\text { cal waste }\end{array}$ & $\begin{array}{l}\text { Tritium, aluminum } \\
\text { nitrate, potassium } \\
\text { hydroxide, nitric acid, } \\
\text { sulfuric acid }\end{array}$ & $\begin{array}{l}\text { RCRA (Sweeney } \\
\text { 1995b) }\end{array}$ \\
\hline $\begin{array}{l}200 \text { Areas Treated } \\
\text { Effluent-Disposal } \\
\text { Facility }\end{array}$ & $\begin{array}{l}\text { Treated liquid effluent } \\
\text { from } 200 \text { Areas }\end{array}$ & Trihalomethane & $\begin{array}{l}\text { Active; WAC permitted } \\
\text { (Bamett at al. 1995b) }^{(a)}\end{array}$ \\
\hline $\begin{array}{l}\text { Low-Level Burial } \\
\text { Grounds (Waste } \\
\text { Management Areas } 1 \\
\text { and 2) }\end{array}$ & Radioactive solid waste & $\begin{array}{l}\text { Various chemical and } \\
\text { radioactive wastes } \\
\text { (b) }\end{array}$ & $\begin{array}{l}\text { RCRA (Last and } \\
\text { Bjornstad 1989) }\end{array}$ \\
\hline
\end{tabular}


Table 6.1. (contd)

\begin{tabular}{|l|l|l|l|}
\hline Facility (period of use) & \multicolumn{1}{|c|}{ Waste Type } & $\begin{array}{l}\text { Constituents of Interest } \\
\text { for Groundwater } \\
\text { Monitoring }\end{array}$ & \multicolumn{1}{|c|}{$\begin{array}{c}\text { Type of Site } \\
\text { (monitoring plan } \\
\text { reference) }\end{array}$} \\
\hline $\begin{array}{l}\text { Liquid Effluent } \\
\text { Retention Facility }\end{array}$ & $\begin{array}{l}\text { 242-A evaporator } \\
\text { process condensate }\end{array}$ & $\begin{array}{l}\text { Ammonium, acetone, } \\
\text { aluminum, 1-butanol, } \\
\text { 2-butanone, tritium, } \\
\text { strontium-90, } \\
\text { ruthenium-106, } \\
\text { cesium-137 }\end{array}$ & RCRA (Schmid 1990) \\
\hline \multicolumn{2}{|c|}{ 600 Area Facilities } \\
\hline $\begin{array}{l}\text { Gable Mountain Pond } \\
\text { (1957-87) }\end{array}$ & $\begin{array}{l}\text { 200-East Area liquid } \\
\text { wastes }\end{array}$ & $\begin{array}{l}\text { Strontium-90, } \\
\text { cesium-137, } \\
\text { ruthenium-106 }\end{array}$ & Inactive \\
\hline $\begin{array}{l}\text { BC Cribs and Trenches } \\
\text { (1956-58) }\end{array}$ & $\begin{array}{l}\text { Uranium recovery waste } \\
\text { supernatant }\end{array}$ & $\begin{array}{l}\text { Ferrocyanide, } \\
\text { radionuclides }\end{array}$ \\
\hline $\begin{array}{l}\text { (a) Groundwater monitored independently of groundwater project. } \\
\text { (b) Present in waste; not found in groundwater. }\end{array}$
\end{tabular}

\subsubsection{Groundwater-Monitoring Requirements and History}

Groundwater monitoring has been conducted in the 200-East Area since the 1940s. Very few monitoring wells existed in the early decades but more were installed in the 1970s and monitored for DOE requirements. Approximately 100 new wells were installed when RCRA monitoring began in the late 1980s. CERCLA investigations in the 1990s resulted in the installation of several wells but relied primarily on data from existing groundwater-monitoring networks and additional wells installed in support of RCRA.

The Atomic Energy Act of 1954 and DOE Order 5400.1 require monitoring to identify and track contaminant plumes. Wells monitored for those requirements in 1996 were listed by Bisping (1996).

\subsection{Conceptual Model}

The most widespread groundwater contaminants of concern originating from the 200-East Area are tritium, nitrate, and iodine-129. These contaminants extend east and southeast of the 200-East Area to the Columbia River and northwest to the gap between Gable Mountain and Gable Butte. A significant plume of technetium-99 at levels above the drinking water standards extends northwest from the 200-East Area fence line toward the gap between Gable Mountain and Gable Butte. This plume area also contains low levels of cobalt- 60 and cyanide. Arsenic is found at levels above drinking water standards in the eastern part of the 200-East Area. Groundwater is locally contaminated with strontium-90 at high levels near Gable Mountain Pond (decommissioned) and at low levels near cribs south of the Plutonium-Uranium 
Extraction Plant. Contamination with plutonium, strontium-90, and cesium-137 is found in the immediate vicinity of the 216-B-5 injection well. Localized uranium and chromium contamination is also found.

The most extensive contaminant plumes are attributable predominantly to liquid discharges to cribs, with some contribution from ponds, ditches, and other sources. Most pond discharge, however, was more dilute and did not contribute to the highest levels of contamination. The ponds, particularly B Pond, did have a large influence on contaminant migration because the large amounts of water that went to the ponds affected flow directions. Groundwater mounding at B Pond remains evident, though the mound is declining since discharge to the pond ceased. Contamination from tank leaks, unplanned releases, and specific retention trenches appears to have produced groundwater contamination of limited extent, though considerable inventory may remain in the vadose zone. No groundwater impact from low-level wasteburial grounds in the 200-East Area has been identified.

Contaminant levels are declining through much of the area. Many short-lived radionuclides detected in the past, such as ruthenium-106 and cobalt-60, are no longer detected or are detected at much lower concentrations. Tritium concentrations near the source areas are declining because of termination of discharge and the subsequent dispersion and decay within the plume. It appears that residual contamination in the vadose zone at many of the sources continues to drain into the groundwater. It is expected that the amount of transport to groundwater will decline with time. Some contaminants that have been retarded by sorption to sediments or that never reached groundwater because of limited discharge volumes (i.e., specific retention trenches) may break through to the water table, and concentrations then could increase. In addition, any uncontrolled discharge, such as leaks from water lines, may enhance transport of contaminants to the groundwater from the vadose zone. Tritium concentrations north of the 300 Area near the Columbia River continue to increase, reflecting the continued spread of contamination at the downgradient plume boundaries. The contamination is predicted not to spread southward beyond the site boundary (Hartman and Dresel 1998).

Several waste streams discharged at the site included chemical complexants along with other radioactive and hazardous constituents. Complexation is known to have enhanced the mobility of some constituents such as cobalt-60. Cyanide, a complexant for cobalt-60, is monitored in the northern part of the area and adjacent 600 Area. Cobalt- 60 concentrations are declining because of its short half-life, but other constituents such as americium, plutonium, and neptunium may also have increased mobility. The data on these constituents and on complexant concentrations are sparse. More work is needed to evaluate the potential for complexant-enhanced mobility of radionuclides before including them in routine monitoring.

Vertical migration of contaminants to deeper parts of the aquifer or deeper aquifers may have occurred through several mechanisms. Significant groundwater mounds developed at a number of facilities. By far, the greatest mounding occurred at B Pond, where monitoring evidence indicates there was some movement of contamination down to the upper basalt-confined aquifer. This mounding produced vertical gradients to transport contamination downward in the sedimentary sequence. Poorly sealed wells may have produced conduits, thus enhancing vertical migration. 
Additional vertical migration probably occurred through the discharge of high-density, high-salt wastes. This dense material migrated down through the aquifer. Few monitoring data are available on the lower parts of the unconfined aquifer because of the paucity of monitoring wells. Dense waste could have moved down-dip along the top of basalt. The unconsolidated sediments are thin in the area where high-density wastes were discharged, increasing the potential for the waste to reach the basalt. Further evaluation of areas where this type of vertical migration may have occurred is needed to determine additional monitoring needs.

A third mechanism for vertical migration is the intersection of the water table by confining layers in the suprabasalt sediments. The lower Ringold mud intersects the water table downgradient of B Pond and dips approximately to the south. This serves to induce downward flow to the sediments below the confining mud. The lower part of the Ringold sediments thus forms a confined aquifer in this area. Although relatively few wells are completed below the lower Ringold mud, this interval is monitored where wells are available. Several wells near B Pond and the 200 Area Treated Effluent Disposal Facility are completed below the lower mud.

\subsection{Monitoring Program}

The surveillance monitoring program in the 200-East Area has been designed to meet several objectives and to complement the RCRA monitoring networks. The first objective is to monitor the extent of plumes emanating from 200-East Area waste sites. Most of these sites have ceased operations and, thus, it is expected that the monitoring network will be suitable to track the rate of dissipation and attenuation of the plumes. To do this, the overall extent of the major plumes will be sampled at 3-year intervals. A combination of geostatistical assessment and site knowledge was used in developing the plumemonitoring system. The planned network has been assessed with a geostatistical model of the plumes, and the network was determined to provide sufficient data for plume tracking. The model used stochastic simulation to provide estimates of concentrations throughout the plume area and a measure of the uncertainties associated with the plume model. These uncertainties were used to rank wells according to their importance to the statistical model. Wells close to other wells and wells in areas where concentrations do not vary greatly received low rankings, while remote wells and wells where concentrations vary considerably over short distances were ranked higher. These rankings were then used by groundwater project scientists to choose wells to delete from the network. The geostatistical model was then used to evaluate the proposed network to ensure that similar results could be obtained with fewer monitoring wells.

Three bands of guard wells will be monitored annually for a longer list of constituents to ensure that the nature of contamination found downgradient of the operational and waste-disposal areas has been sufficiently characterized. These bands are shown in Figure 6.1; the wells are listed in Table 6.2. One band is located in the gap between Gable Mountain and Gable Butte and serves to detect contaminant movement to the north. The second band is located to the southeast of the 200-East Area and detects contamination moving into the southern and eastern parts of the site. The third band is along the Columbia River to provide assurance that offsite impacts are identified. In addition to the known contaminants, 


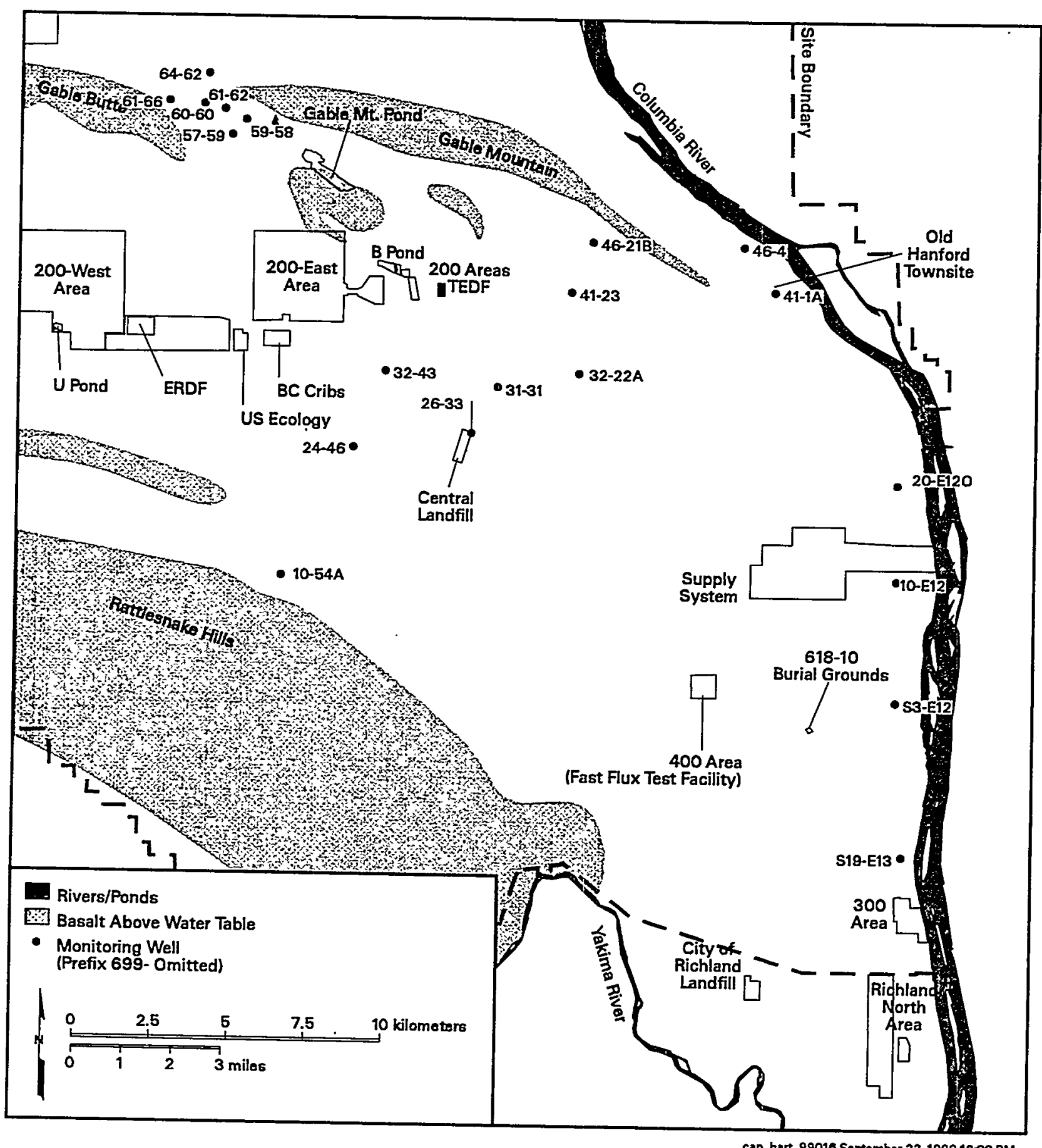

Figure 6.1. Locations of 200-East Area Guard Wells 
Table 6.2. 200-East Area Guard Wells

\begin{tabular}{|l|l|l|}
\hline \multicolumn{1}{|c|}{ Gap } & \multicolumn{1}{|c|}{ Southeast } & \multicolumn{1}{c|}{ River } \\
\hline $699-57-59$ & $699-10-54 \mathrm{~A}^{(\mathrm{a})}$ & $699-10-\mathrm{E} 12$ \\
$699-59-58$ & $699-24-46$ & $699-20-\mathrm{E} 12 \mathrm{O}$ \\
$699-60-60$ & $699-26-33$ & $699-41-1 \mathrm{~A}$ \\
$699-61-62$ & $699-31-31$ & $699-46-4$ \\
$699-61-66$ & $699-32-22 \mathrm{~A}$ & $699-\mathrm{S3}-\mathrm{E} 12$ \\
$699-64-62$ & $699-32-43$ & $699-S 19-E 13^{(\mathrm{b})}$ \\
& $699-41-23^{(\mathrm{a})}$ & \\
& $699-46-21 \mathrm{~B}^{(\mathrm{a})}$ & \\
\hline Constituent List: Inductively coupled-plasma metals; anions; gross \\
alpha, beta, and gamma; strontium-90; technetium-99; tritium; total \\
organic halides; total organic carbon; and alkalinity. \\
(a) Reduced list - Sample tritium, alpha, beta, anions annually; Full \\
(b) Also monitors southern portion of the Hanford Site. \\
\hline
\end{tabular}

wells in these bands will be monitored for inductively coupled-plasma metals, anions, gross alpha, gross * beta, gamma, strontium-90, technetium-99, tritium, total organic halides, total organic carbon, and alkalinity.

The monitoring network is also designed to complement the RCRA detection and assessment monitoring of contaminant sources. The RCRA-monitoring networks only address sources, containing hazard- . ous constituents, that were operational after 1985. RCRA and past-practice source monitoring serves to ensure that concentrations of groundwater contaminants are declining near the most significant sources and to detect the breakthrough of new contamination from the vadose zone. The source monitoring places a high priority on the potentially largest contaminant sources and on areas near the 200-East Area boundary. This helps ensure that any new contamination will be detected before it moves out of the operational area.

Locations of monitoring wells for the 200-East Area are illustrated in Figure 6.2 (wells in the 600 Area were shown in Figure 4.8). Wells and constituents are listed in Appendix A. 


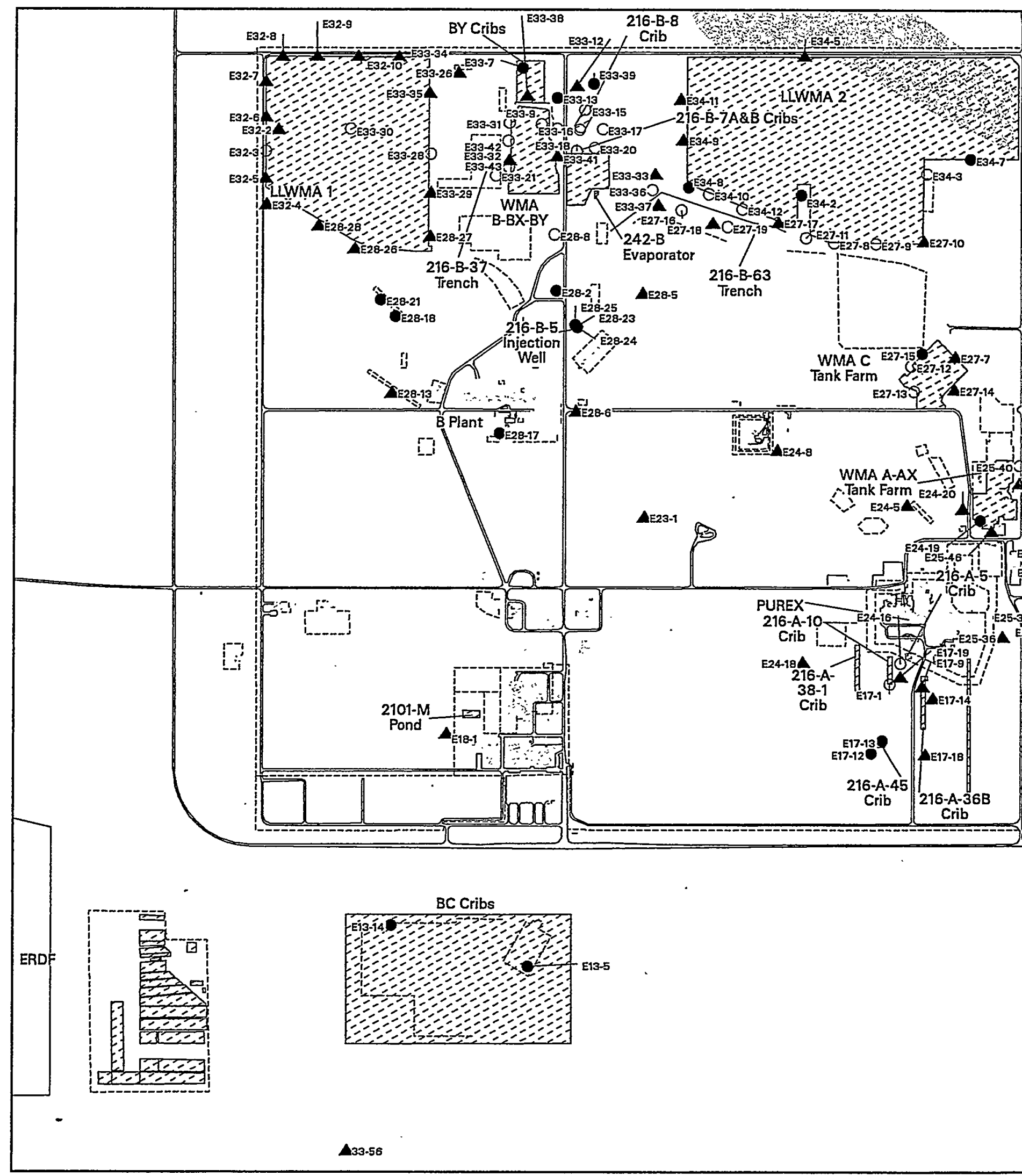

Figure 6.2. Groundwater Project 

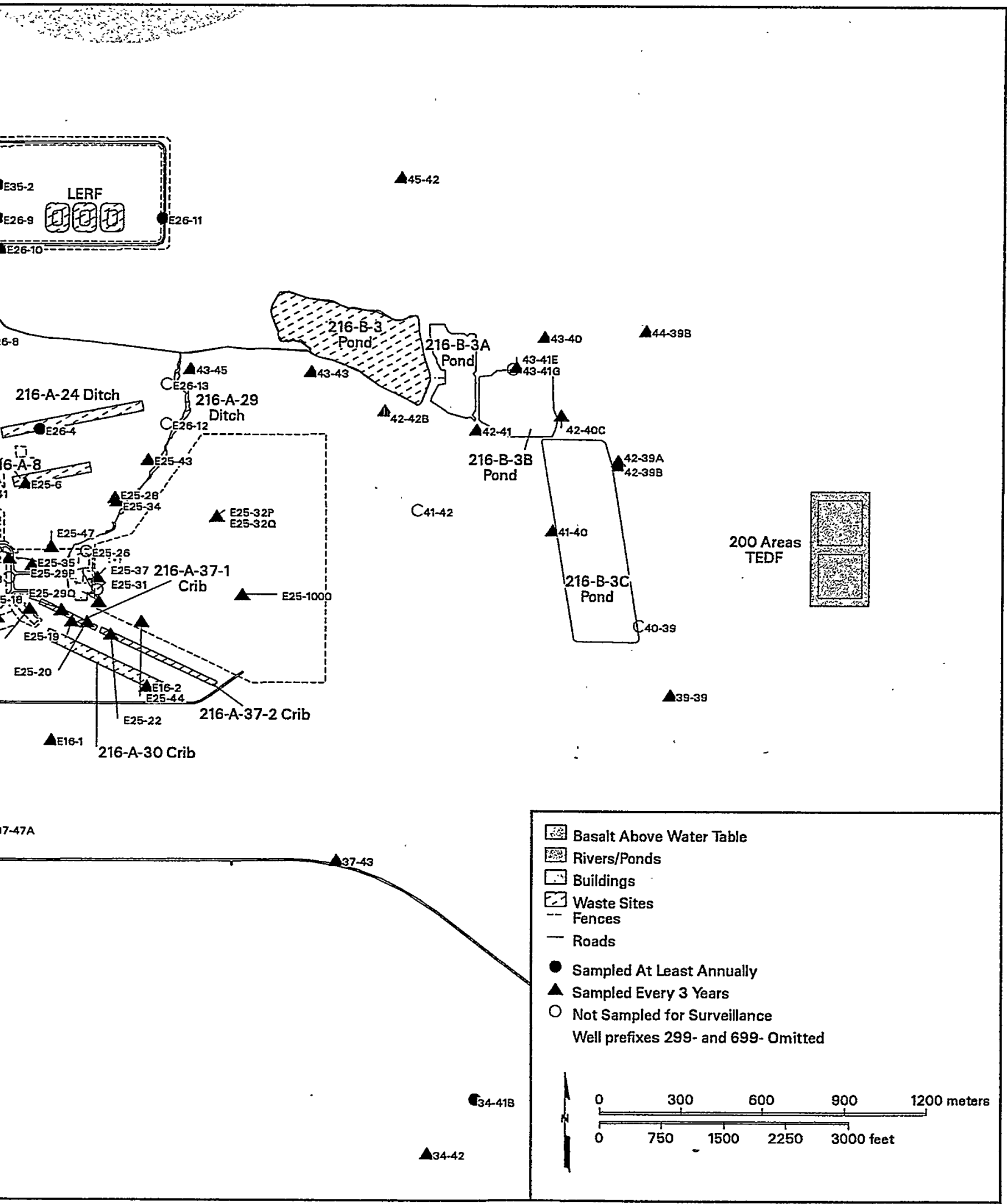


\subsection{Area}

\subsection{Background}

This section covers activities in the 400 Area, the location of the Fast Flux Test Facility, a liquid sodium-cooled reactor. The reactor is on standby, pending a restart decision for the production of medical isotopes and tritium.

Primary local groundwater-monitoring activities include the area around the $4608 \mathrm{~B} / \mathrm{C}$ Ponds (also called the 400 Area process ponds), which receive wastewater effluent. The water supply for the 400 Area, including the drinking water supply, is also monitored by sampling wells completed in the unconfined aquifer system.

\subsubsection{Waste Sites}

The 400 Area process ponds are located north of the 400 Area perimeter fence and are unlined infiltration ponds that receive wastewater from the 400 Area facilities (Figure 7.1). The waste stream consists primarily of cooling water and intermittent small contributors such as sinks and drains.

\subsubsection{Groundwater-Monitoring Requirements and History}

The 400 Area process ponds are monitored in accordance with State Waste Discharge Permit ST4501, issued on August 1, 1996 and modified on February 10, 1998. This integrated groundwater-monitoring plan provides information related to sampling activities and quality assurance/quality control to ensure that the data needs of various users are satisfied. The primary objective of groundwater monitoring at this facility is to ensure that wastewater entering the ponds meets acceptable standards and does not adversely affect local groundwater quality. The monitoring network includes a downgradient well (699-2-7) and an upgradient well (699-8-17), shown in Figure 4.8. In addition, a second downgradient well has been installed near the ponds (699-2-6A). Constituents analyzed in quarterly groundwater samples, as specified by the discharge permit, include unfiltered metals (cadmium, chromium; lead, mercury, and manganese), $\mathrm{pH}$, sulfate, and total organic carbon. In addition, the wells are co-sampled for surveillance monitoring for other constituents, as indicated in Appendix A.

Nitrate is the only contaminant that has been consistently identified at concentrations above regulatory limits in the local groundwater-monitoring network for the 400 Area process ponds, where it has been monitored in well 699-2-7 since 1986 . This is attributed to a sanitary sewage lagoon located immediately west and upgradient of the ponds. Disposal to the lagoon has been discontinued, and the lagoon has been backfilled; thus, groundwater contamination from this source is expected to diminish with time.

Slightly elevated manganese concentrations have been identified in the effluent wastewater discharged to the ponds. A few of the manganese values are in excess of the discharge permit ( $50 \mu \mathrm{g} / \mathrm{L}$, 
400 Area Process Ponds

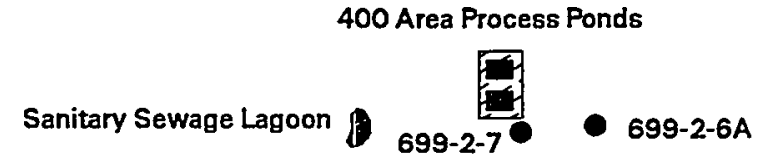

ja

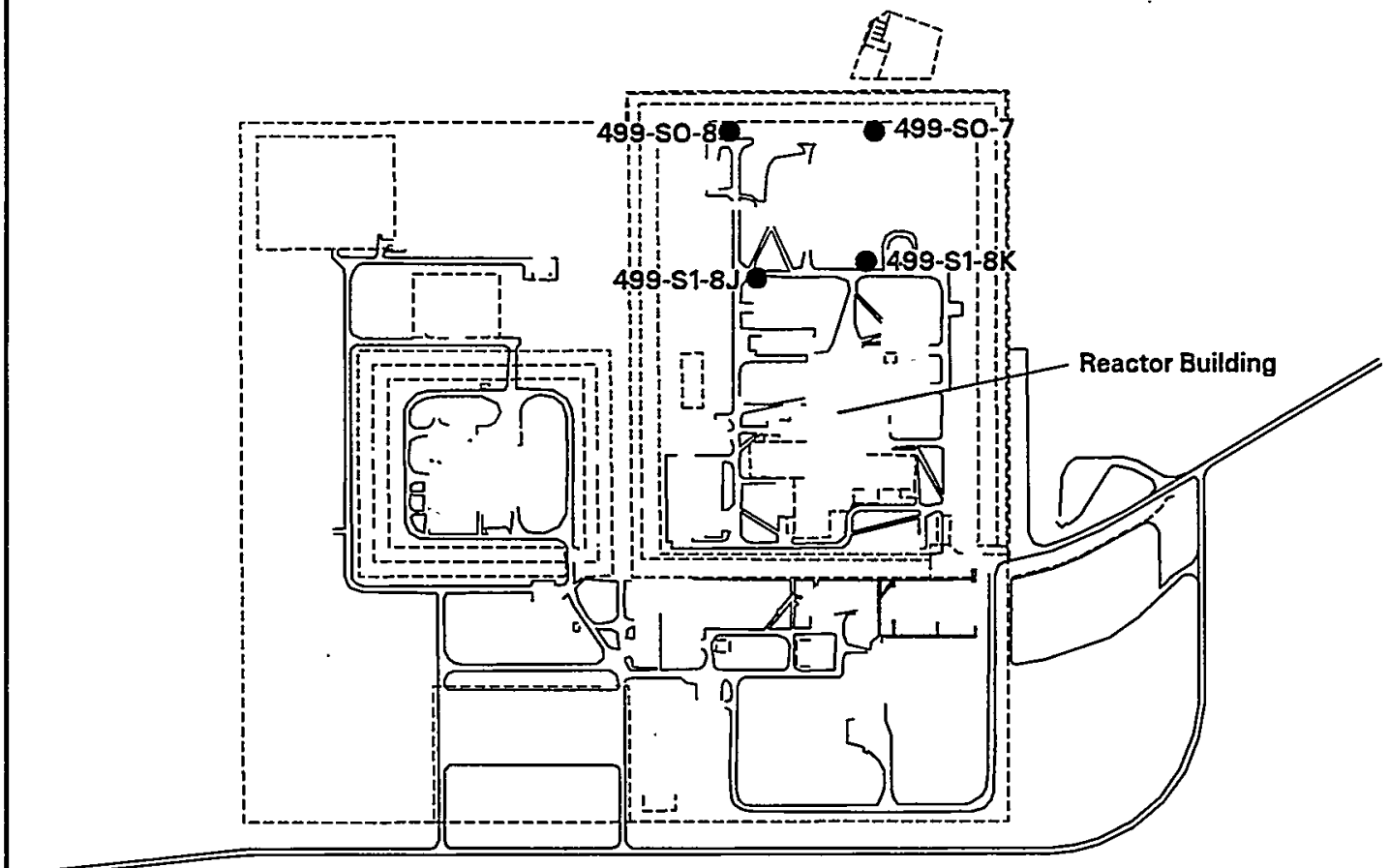

Rivers/Ponds

$\square$ Buildings

[-] Waste Sites

Fences

- Roads
Sampled At Least Annually

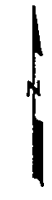

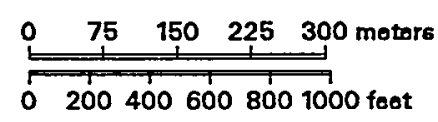

can_hart_99015 September 21, 1999 1:28 PM

Figure 7.1. Groundwater Project Well Locations: 400 Area 
unfiltered). Groundwater-sampling data suggest that the elevated manganese values are unlikely to have been introduced by the water-supply wells and probably represent particulate matter derived from corrosion in tanks or disposal lines.

The primary groundwater-monitoring compliance issue related to the 400 Area water supply is related to tritium. Wells 499-S0-7 and 499-S0-8, the original water-supply wells, were completed near the top of the unconfined aquifer and have been monitored since 1972. When tritium contamination was detected in the water supply, an additional well (499-S1-8J) was drilled in the lower unconfined aquifer in 1985. Although well 499-S1-8J is currently the primary water-supply well, wells 499-S0-7 and 499-S0-8 are still used for backup supply and emergency uses.

Tritium is consistently detected at levels above the interim $20,000-\mathrm{pCi} / \mathrm{L}$ drinking water standard in the backup supply wells, but well below it in the primary supply well. Because the backup wells are seldom used, monthly water-supply sampling results indicate that the concentration in the drinking water does not exceed a dosage level of $4 \mathrm{mrem} / \mathrm{yr}$ if ingested at the average annual rate of consumption. Moreover, the dose-conversion factor used in setting the interim drinking water standard for tritium is more conservative than that used in more current methodology (Hartman and Dresel 1998).

\subsection{Conceptual Model}

Water-level contours indicate that groundwater generally flows from west to east across the 400 Area. In addition, tritium and nitrate plumes, which originate in the 200-East Area, indicate that groundwater flows toward the east to southeast. The tritium plume is detected in the 400 Area water-supply wells, as discussed above. Tritium levels are lower in the vicinity of the 400 Area process ponds as a result of dilution effects. However, nitrate levels are currently elevated in the vicinity of the process ponds, apparently from the former disposal of sanitary sewage to a nearby lagoon, as indicated above.

\subsection{Monitoring Program}

Monitoring well locations in the 400 Areas are presented in Figure 7.1. Upgradient well 699-8-17 was shown in Figure 4.8. Constituents monitored and sampling frequencies are presented in Appendix A. 


\subsection{0 and Richland North Areas}

The 300 and Richland North Areas include the southern portion of the Hanford Site and adjacent area to the south between the Yakima and Columbia Rivers. The 300 Area is located along the Columbia River in the southeastern portion of the Hanford Site. The Richland North Area, though not formally defined, includes the former 1100 Area and the 3000 Area, part of the 600 Area adjacent to the 300 Area, and parts of nearby Richland. Figure 8.1 shows the locations of these two areas.

\subsection{Background}

The 300 Area has been used for research-and-development and nuclear fuel-fabrication process activities associated with uranium fuel elements for nuclear reactors. The Richland North Area consists of a variety of both onsite and offsite land uses, including municipal, industrial, and agricultural. Municipal and industrial facilities and agricultural activities in the Richland North Area influence groundwater. Offsite facilities of particular interest with respect to groundwater include the City of Richland's North Well Field and recharge basins, Siemens Power Corporation, Richland Landfill, Lamb-Weston Richland Plant, Interstate Nuclear Services, and Allied Technology Group. Offsite agricultural irrigation influences groundwater over a wide area in the Richland North Area.

\subsubsection{Waste Sites, Discharges, and Groundwater Operable Units}

In the 300 Area, inactive waste sites known to have received liquid waste containing uranium and other known or suspected contaminants include the 316-5 process trenches and the 316-1 and 316-2 process ponds. These are the primary sites affecting groundwater contamination. Other sites that received wastes include sanitary septic tanks, trenches, and tile fields; ash pits; filter backwash ponds; and.a number of burial grounds. The 300 Area also contained underground tanks for storing gasoline and diesel fuels.

The 316-5 process trenches require groundwater monitoring to meet RCRA requirements because the trenches are regulated as dangerous waste surface impoundments. The process trenches were modified as part of an expedited response action in 1991, and discharges to the trenches ceased in 1994. The 316-1 and 316-2 process ponds, monitored to meet CERCLA requirements, received uranium-contaminated wastewater until 1975 when the process trenches began receiving the wastewater. The storage tanks were monitored under the state's underground storage tank program in the early $1990 \mathrm{~s}$, but monitoring is no longer required by the state. Groundwater in the 300 Area is part of the 300-FF-5 Operable Unit.

Waste sites in the Richland North Area include the inactive Horn Rapids Landfill in the 600 Area and a number of disposal pits and underground storage tanks in the former 1100 Area. Groundwater associated with these waste sites is monitored to meet CERCLA requirements. The 1100-EM-1 Operable Unit ROD (1993) required groundwater monitoring at a point of compliance downgradient from the 


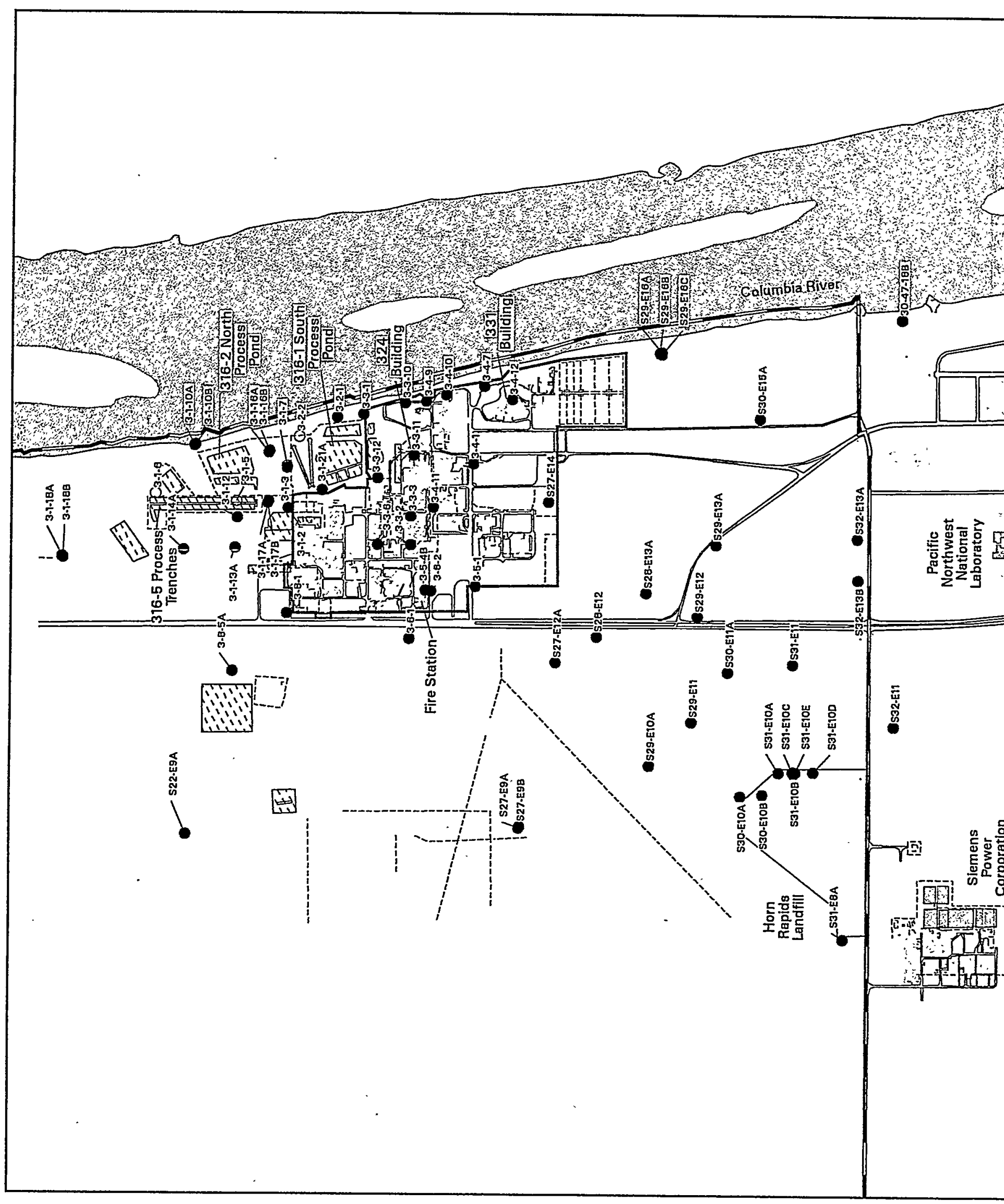




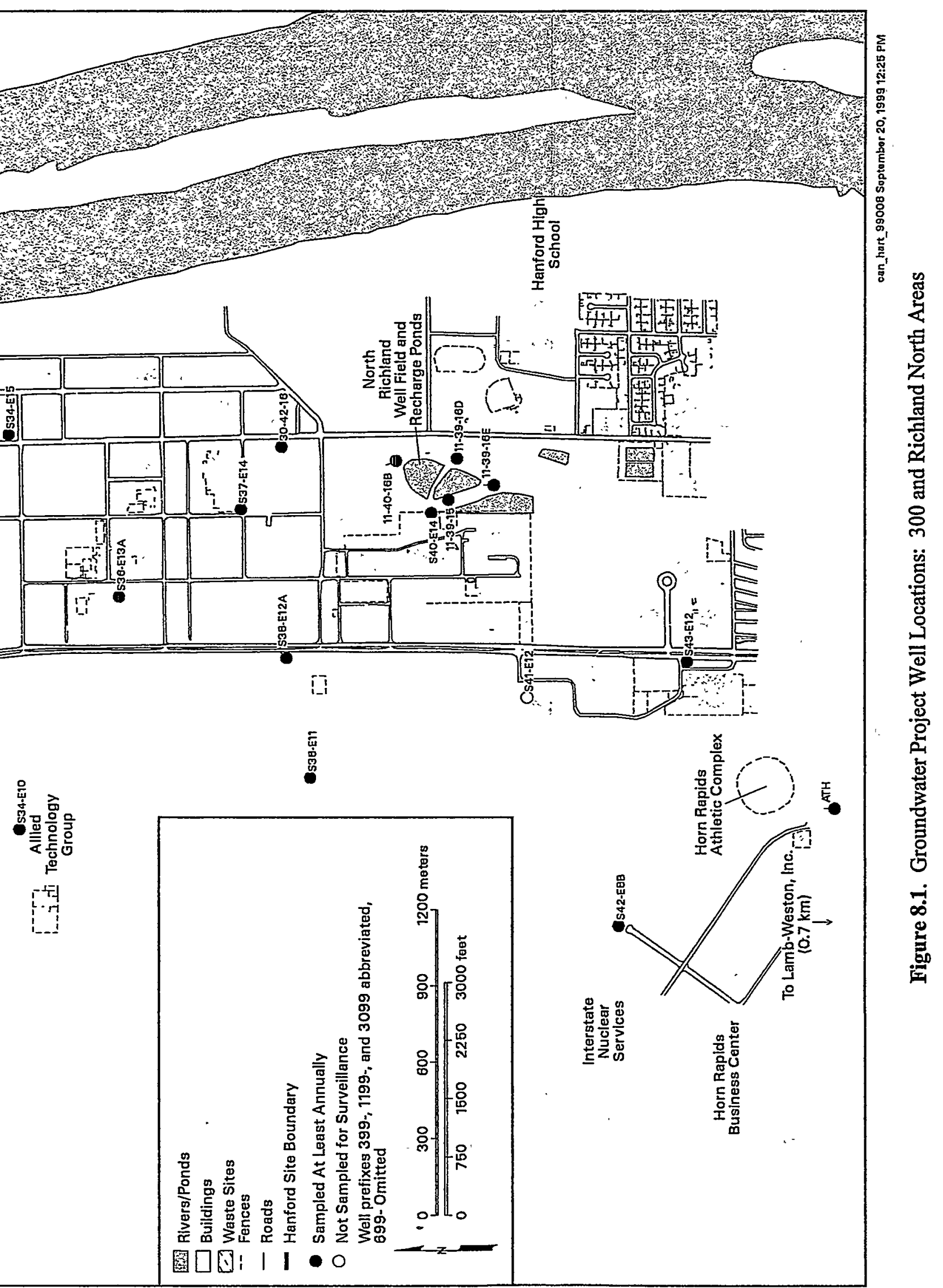


inactive Horn Rapids Landfill. There are no waste sites requiring RCRA groundwater monitoring in the Richland North Area. The waste sites in the 300 and Richland North Areas requiring groundwater monitoring are listed in Table 8.1 along with their waste types, period of use, associated constituents in groundwater, and regulatory program.

\subsubsection{Offsite Sources}

Probable sources of groundwater contamination that originated from the Richland North Area off the Hanford Site include Siemens Power Corporation, agricultural irrigation, and Lamb-Weston Richland Plant. Siemens Power Corporation is located adjacent to the Hanford Site boundary southwest of the Horn Rapids Landfill, and a surface impoundment system at the site contributed to solvent and nitrate contamination in groundwater. Fertilizers applied to the agricultural fields upgradient (south) of Siemens Power Corporation and potato-processing waste from the Lamb-Weston Richland Plant are probable sources of nitrate. The Richland Landfill, Interstate Nuclear Services, and Allied Technology Group are not known to contribute to groundwater contamination on the Hanford Site.

Table 8.1. Selected Waste Sites in the 300 and Richland North Areas

\begin{tabular}{|c|c|c|c|}
\hline Facility (period of use) & Waste Type & $\begin{array}{l}\text { Constituents of Interest } \\
\text { for Groundwater } \\
\text { Monitoring }\end{array}$ & $\begin{array}{l}\text { Type of Site } \\
\text { (monitoring plan } \\
\text { reference) }\end{array}$ \\
\hline \multicolumn{4}{|c|}{300 Area } \\
\hline $\begin{array}{l}\text { 316-5 process trenches } \\
(1975-94)\end{array}$ & $\begin{array}{l}\text { Variety of chemical and } \\
\text { uranium wastes }\end{array}$ & $\begin{array}{l}\text { Uranium, trichloro- } \\
\text { ethylene, cis-1,2- } \\
\text { dichloroethylene, metals, } \\
\text { nitrate }\end{array}$ & $\begin{array}{l}\text { RCRA (Lindberg } \\
\text { et al. 1995) }\end{array}$ \\
\hline $\begin{array}{l}316-1 \text { (south) and } 316-2 \\
\text { (north) process ponds } \\
(1940 \text { s-75) }\end{array}$ & $\begin{array}{l}\text { Variety of chemical and } \\
\text { uranium wastes }\end{array}$ & $\begin{array}{l}\text { Uranium, trichloro- } \\
\text { ethylene, cis-1,2- } \\
\text { dichloroethylene }\end{array}$ & $\begin{array}{l}\text { Past-practice } \\
\text { (300-FF-1 and -5 } \\
\text { Operable Units, } \\
\text { ROD 1996b, DOE } \\
\text { 1996d) }\end{array}$ \\
\hline \multicolumn{4}{|c|}{ Richland North Area } \\
\hline $\begin{array}{l}\text { Hom Rapids Landfill } \\
(1950 \mathrm{~s}-70)\end{array}$ & $\begin{array}{l}\text { Office and construction } \\
\text { wastes, asbestos, sewage } \\
\text { sludge, fly ash }\end{array}$ & $\begin{array}{l}\text { Trichloroethylene, break- } \\
\text { down products of } \\
\text { trichloroethylene (vinyl } \\
\text { chloride, 1,1-dichloro- } \\
\text { ethylene), chromium, } \\
\text { technetium-99, nitrate }\end{array}$ & $\begin{array}{l}\text { Past-practice } \\
\text { (1100-EM-1 Opera- } \\
\text { ble Unit, ROD 1993, } \\
\text { DOE 1995c) } \\
\text {.. }\end{array}$ \\
\hline $\begin{array}{l}\text { Siemens Power } \\
\text { Corporation process } \\
\text { lagoons (offsite) } \\
\text { (1971-present) } \\
\end{array}$ & $\begin{array}{l}\text { Ammonia, fluoride, nitrate, } \\
\text { radionuclides (primarily } \\
\text { uranium) }\end{array}$ & Trichloroethylene, nitrate & $\begin{array}{l}\text { Active RCRA; } \\
\text { Siemens }(1996)^{(a)}\end{array}$ \\
\hline Lamb-Weston (offsite) & Potato-processing wastes & Nitrate & Active \\
\hline Agriculture (offsite) & Fertilizers & Nitrate & Active \\
\hline
\end{tabular}


The City of Richland's North Well Field and recharge basins, located in the south-central part of the Richland North Area, are the primary influence on groundwater-elevation changes in the area. The well field serves as a secondary water supply for the City of Richland, and the basins recharge the unconfined aquifer with Columbia River water. The net recharge causes a groundwater mound to form in this area and decreases nitrate levels in groundwater to less than ambient.

Irrigation applied to agricultural fields contributes to groundwater recharge during the growing season. As a result, this contributes to groundwater flow to the northeast, east, and southeast.

\subsubsection{Groundwater-Monitoring Requirements and History}

Extensive groundwater monitoring has been conducted in the 300 Area as far back as 1975, when the 316-5 process trenches replaced the 316-1 and 316-2 process ponds as the main facility for disposal of uranium-contaminated wastewater. The earliest major study on groundwater contamination in the 300 Area was in 1977 (Lindberg and Bond 1979). A site-specific program of groundwater monitoring of the 300 Area has been conducted since 1977. In 1985, interim-status groundwater monitoring of the process trenches was initiated under RCRA, which required additional wells to be installed (Schalla et al. 1988). The RCRA program went into final-status groundwater monitoring in 1996 (Lindberg et al. 1995). In response to the Tri-Party Agreement (Ecology et al. 1989), CERCLA activities were initiated in the early 1990s and included additional groundwater monitoring. An expedited response action was implemented in 1991 to remove sources of contamination and resulted in lower contaminant concentrations in groundwater downgradient from the process trenches. An interim remedial action required continued groundwater monitoring of contaminants in the 300 Area (ROD 1996b).

Groundwater well installation and monitoring began in the 1100 Area in 1988 after a limited groundwater-sampling effort in 1986 revealed low levels of contaminants (DOE 1990). A study was conducted in 1989-1992 and included well installation and groundwater monitoring to determine the nature and extent of groundwater contamination in the 1100 Area (DOE 1992). In 1993, continued and expanded groundwater monitoring in the 1100 Area were required (ROD 1993). In response to the ROD, additional well installation and monitoring were implemented at the inactive Horn Rapids Landfill (DOE 1995c). The ROD required the monitoring of trichloroethylene in groundwater downgradient of the inactive Horn Rapids Landfill. The ROD also required monitoring of trichloroethylene breakdown products and nitrate. The monitoring of nitrate was needed because its concentrations were above the maximum contaminant levels for nitrate.

The surface impoundment system at Siemens Power Corporation consists of six lagoons, which are regulated under the Revised Code of Washington, Title 70, Chapter 105 (Siemens Power Corporation 1997). Siemens Power Corporation has monitored groundwater at their facility since 1994 to meet the requirements of RCRA interim-status facilities. 


\subsection{Conceptual Model}

The most widespread contaminants of concern in the 300 and Richland North Areas are tritium and nitrate. Groundwater is locally contaminated with uranium and trichloroethylene. The movement and distribution of these contaminants in groundwater are heavily influenced by Columbia River stage, a recharge mound at the Richland North Well Field, and agricultural irrigation practices.

The tritium plume is derived from past wastewater-disposal activities in the 200-East Area and represents the southern margin of the sitewide plume that is encroaching into the 300 Area. Tritium migrates across the northeastern portion of the 300 Area from the north and enters the Columbia River. Tritium levels have generally been steady with time in and north of the 300 Area in recent years. The southward migration of tritium is limited to the 300 Area because of the following factors:

- Groundwater is recharged by the Yakima River, flows generally from west to east, and discharges to the Columbia River.

- Recharge from agricultural irrigation between the Richland Landfill and the former 1100 Area contributes to eastward groundwater flow.

- Net recharge at the City of Richland's North Well Field has resulted in a groundwater mound that directs groundwater flow outward, including a component to the north.

In the 300 Area, wastewater effluent, containing uranium and chlorinated solvent compounds, percolated through the soils from leaking process trenches and ponds for approximately 50 years. These constituents were driven down through the soils in the vadose zone beneath the waste sites by subsequent effluent discharges and natural recharge. As the constituents were carried downward, some were sorbed to sediments and trapped in soil moisture and some reached groundwater. Uranium in groundwater migrates toward and enters the Columbia River.

Uranium concentrations in groundwater fluctuate indirectly in response to river-stage changes. As the river stage rises, groundwater near the river rises into a portion of the vadose zone. As a result, uranium is desorbed from the sediments and mobilized, increasing the uranium concentrations in groundwater. As the groundwater levels drop, uranium concentrations decrease because the thickness of the saturated sediments from which uranium desorbs decreases.

Chlorinated solvent compounds are generally found in the deeper portion of the unconfined aquifer beneath the process trenches and ponds. They have been found in the upper portion of the unconfined aquifer for brief periods (e.g., tetrachloroethylene in 1998). Two conceptual model hypotheses have been suggested for the deeper occurrences. One hypothesis is that dissolved chlorinated compounds in groundwater were transported by a downward vertical hydraulic gradient created when discharged effluent to the ponds and trenches recharged the aquifer, causing groundwater levels to rise. The second hypothesis is that an immiscible phase that is denser than water was driven to the bottom of the unconfined aquifer by density and rested on top of the silty clay unit. A portion of the dense phase would then dissolve into the aqueous phase. 
A nitrate plume is migrating toward the 300 Area from the southwest toward the Columbia River. This area also contains a trichloroethylene plume. Nitrate contamination is the result of offsite industrial and agricultural uses. Wastewater effluent containing ammonia was discharged to lagoons at Siemens Power Corporation. Effluent has apparently leaked to the underlying soils from the lagoons, and some of the ammonia reached groundwater. Under aerobic conditions, the ammonia degrades relatively quickly to nitrate, which is highly mobile in groundwater. In agricultural areas to the southwest, fertilizers containing nitrate are applied during the growing season. As irrigation is applied, the dissolved nitrate is carried downward through the soils and is taken up by crops in the root zone. However, some of the nitrate is carried downward below the root zone by irrigation recharge and reaches groundwater.

Trichlorothylene contamination is suspected to be the result of offsite industrial solvent use at Siemens Power Corporation. Solvents were used during installation, cleaning, and repairing of lagoon liners over a 10-year period between 1978 and 1988. Excess solvents came into contact with the soils by spillage and were driven downward into the vadose zone and reached groundwater, which is very shallow in this area. On reaching groundwater, trichloroethylene is very mobile. One hypothesis has been suggested that natural attenuation may have reduced the mass of the trichloroethylene in groundwater. Natural attenuation in groundwater can occur by volatilization through passive pumping and biodegradation. Measurable trichloroethylene concentrations were observed in soil gas in the vicinity of the inactive Horn Rapids Landfill (Evans 1989). In FY 1999, only two wells showed trichloroethylene concentrations above the MCL. The wells are located immediately downgradient of the Horn Rapids Landfill.

\subsection{Groundwater-Monitoring Network}

Wells, constituents, and frequencies are listed in Appendix A. Well locations were shown in Figure 8.1. Geostatistical assessment and current knowledge of the site were used in developing the monitoring network. Geostatistical assessment was used only in developing the monitoring network for the primary constituents of concern (see Chapter 6.0).

The primary constituents of concern in the 300 and Richland North Areas are tritium and nitrate. Constituents of concern on a localized scale in the 300 Area include uranium, strontium-90, cis-1,2dichloroethylene, and trichloroethylene. Trichloroethylene is also a local contaminant in the Richland North Area. Special considerations in these areas include tracking the movement of the leading edges of the plumes that are near the City of Richland, monitoring effects of river-stage changes, and monitoring wells downgradient from potential offsite contaminant sources.

One objective is to monitor the extent of groundwater contamination in the 300 and Richland North Areas to ensure that contaminants have not migrated offsite and have not impacted wells in the City of

Richland. This requires intensive monitoring near the leading edges of the plumes, in areas along the site boundary, and in areas where concentrations are low. Monitoring in areas where levels are low provides a baseline from which to determine concentration changes and, thus, early detection of offsite migration. An enrichment technique is used to measure tritium at lower detection limits $(\sim 10 \mathrm{pCi} / \mathrm{L})$ than provided by the standard method. 
In FY 1999, tritium became elevated above previous trends in some wells in the Richland North Area. The groundwater project conducted special sampling to investigate the change, and the FY 2000 schedule (Appendix A) was modified accordingly. Additional changes may be required as the investigation continues.

Another objective of monitoring the Richland North Area is to define plumes that have migrated onto the site from offsite sources. This monitoring is needed to show impacts to onsite groundwater and to show that groundwater contamination attributed to these plumes is not derived from onsite waste sites. 


\subsection{Area Non-Operational Monitoring Activities}

\subsection{Background}

The 600 Area includes those parts of the Hanford Site not specifically included within the boundaries of the operational areas, though many of the 600 Area wells serve to monitor large contaminant plumes with their sources in the operational areas. The 600 Area also includes those areas east and north of the Columbia River, though no Hanford Site disposal facilities are located in that area.

This section largely addresses those parts of the 600 Area of the Hanford Site not included in the monitoring activities associated with the operational areas discussed in the other sections. These wells provide a basis for defining background groundwater chemistry. In addition, monitoring of chemistry and hydraulic head data is conducted within confined aquifers. Specifically, the region addressed in this section is that portion of the 600 Area west of the 200-West, east and north of the Columbia River, and several facilities not covered in other sections of this plan.

\subsubsection{Waste Sites}

The Central Landfill, 618-10 burial ground, and 316-4 crib are facilities located in the 600 Area that are not included in other sections of this plan and are discussed below. The Gable Mountain Pond and BC Cribs were included in Chapter 6.0 because they were associated with 200-East Area operations.

Agricultural activities in the area west of the Hanford Site contribute nitrate to the western portion of the 600 Area. Similar impacts of agriculture are recognized in the 600 Area north and east of the Columbia River.

\subsubsection{Central Landfill}

The Central Landfill is located approximately $5.5 \mathrm{~km}$ southeast of the 200-East Area and consists of the Solid Waste Landfill and the Nonradioactive Dangerous Waste Landfill, which are currently considered separately under differing regulations (Table 9.1).

\subsubsection{618-10 Burial Ground and 316-4 Crib}

The burial ground and adjacent crib are located southeast of the 400 Area. The burial ground operated from 1954 to 1963 and received a variety of low- to high-activity radioactive wastes, mostly composed of fission products with some plutonium-contaminated material (DOE 1996e). These wastes were disposed in caissons and trenches and may have included liquid and solid waste forms.

The crib began receiving uranium-bearing waste solutions in 1948 and continued to receive nitrate, hexone, and organic wastes periodically through at least 1962 . This șite was investigated as part of a CERCLA limited field investigation for the 300-FF-2 Operable Unit (DOE 1996e). 
Table 9.1. Selected Waste Sites in the 600 Area

\begin{tabular}{|c|c|c|c|}
\hline Facility (period of use) & Waste Type & $\begin{array}{l}\text { Constituents of Interest } \\
\text { for Groundwater } \\
\text { Monitoring }\end{array}$ & $\begin{array}{c}\text { Type of Site } \\
\text { (monitoring plan } \\
\text { reference) }\end{array}$ \\
\hline $\begin{array}{l}618-10 \text { burial ground and } \\
316-4 \text { crib (1948-62) }\end{array}$ & $\begin{array}{l}\text { Low- to high-activity } \\
\text { radioactive waste }\end{array}$ & $\begin{array}{l}\text { Nitrate, hexone, organic } \\
\text { wastes }\end{array}$ & $\begin{array}{l}\text { Past-practice (300-FF-2 } \\
\text { Operable Unit) }\end{array}$ \\
\hline Solid Waste Landfill & $\begin{array}{l}\text { Solid waste, sewage, } \\
\text { garage wash water }\end{array}$ & Organics & $\begin{array}{l}\text { WAC permitted (Hodges } \\
\text { 1993) }\end{array}$ \\
\hline $\begin{array}{l}\text { Nonradioactive } \\
\text { Dangerous Waste } \\
\text { Landfill }\end{array}$ & $\begin{array}{l}\text { Asbestos, laboratory } \\
\text { wastes, solvents, } \\
\text { batteries, mercury }\end{array}$ & Organics & $\begin{array}{l}\text { RCRA (Lindberg and } \\
\text { Hartman (1999) }\end{array}$ \\
\hline
\end{tabular}

\subsubsection{Groundwater-Monitoring Requirements and History}

Monitoring of groundwater levels and contaminant concentrations in the 600 Area were initiated in the 1940s. Water-table maps of the unconfined aquifer have been prepared at various times since 1944. The primary monitoring objective is to obtain data needed to track major groundwater-contaminant plumes across the site as required by the Atomic Energy Act of 1954 and its implementing orders. Additional wells were installed around the Central Landfill in 1986-1987 for RCRA and landfill monitoring.

\subsection{Conceptual Model}

Groundwater levels indicate that flow directions in the 600 Area west of the 200-West Area are generally from west to east. This reflects natural recharge and irrigation input into the upper Cold Creek and Dry Creek Valleys (Hartman and Dresel 1998, Section 3.6). Significant contamination is not present in this area, though nitrate is present in certain wells. It is inferred that irrigation is the primary source of nitrate in this area.

Movement of tritium and nitrate plumes and measurement of water levels provide a basis for inferring groundwater-flow directions in the 600 Area across the central and eastern portions of the Hanford Site. The tritium and nitrate plumes, which originate in the 200-East Area and pass beneath the Central Landfill, indicate that the principal direction of groundwater flow is toward the southeast and east.

The rate of groundwater flow beneath the landfill is estimated to be on the order of 1.2 to $1.8 \mathrm{~m} / \mathrm{d}$, based on site-specific hydrologic testing and the observed hydraulic gradients. However, groundwatervelocity estimates based on tritium and nitrate concentrations and tracer test results indicate groundwatertransport rates of 6 to $>30 \mathrm{~m} / \mathrm{d}$. The lack of a detectable head difference in several well pairs located at the Central Landfill indicates that the vertical gradient within the upper portion of the aquifer is negligible. 
The Central Landfill appears to have had little impact on Hanford Site groundwater, owing to minimal disposal of liquids at this facility. Associated groundwater monitoring consists primarily of measurement of RCRA indicator parameters ( $\mathrm{pH}$, specific conductance, total organic carbon, and total organic halides), though minor (below maximum contaminant level) contamination with chlorinated hydrocarbons exists. Localized contamination of groundwater with uranium and hydrocarbons exists in the vicinity of the 618-10 burial ground and 316-4 crib.

Monitoring of the chemistry and hydraulic head in the upper basalt-confined aquifer is also conducted at the Hanford Site. The primary objective of this activity is to determine if contamination is moving downward from the unconfined aquifer. In general, the hydraulic gradient appears to be directed downward over most of the central portion of the Hanford Site, though the gradient is directed upward in the eastern portion of the site.

Water-level elevations north and east of the Columbia River are much greater than on the Hanford Site. The water-table elevation to the east of the Columbia River is currently 50 to $150 \mathrm{~m}$ higher than on the Hanford Site. Groundwater flow in the unconfined aquifer system north and east of the Columbia River follows the bedrock structure and is toward the Columbia River. The water-table configuration in these areas largely reflects recharge from irrigation.

Steep hydraulic gradients are observed along the eastern bank of the Columbia River east of Gable Mountain in the area known as White Bluffs and also in the area east of the river and north of the 300 Area. These steep gradients represent a series of springs and seepage faces along the bluffs, where groundwater flow intersects the ground surface. Groundwater flow in these areas is controlled primarily by low-permeability zones (i.e., caliche) near the top of the bluffs and other low-permeability horizons in the upper Ringold Formation (Hartman and Dresel 1998, Section 3.9).

\subsection{Monitoring Program}

Except for the monitoring networks at the Central Landfill, the 618-10 burial ground, and the 316-4 crib, the 600 Area monitoring activities discussed are not directly related to specific Hanford Site facilities. Monitoring wells are maintained west of the 200-West Area and are sampled primarily for nitrate, which is probably related primarily to offsite agricultural activities.

There are six DOE wells located in the 600 Area north and east of the Columbia River, three of which have been used for contaminant-monitoring activities. Currently, monitoring of contaminant concentrations in this area is limited to well 699-42-E9B (shown in Figure 4.8).

Monitoring well locations for the Central Landfill are shown in Figure 9.1 (wells in the rest of the 600 Area were presented in Figure 4.8). Constituents monitored and sampling frequencies are presented in Appendix A. 


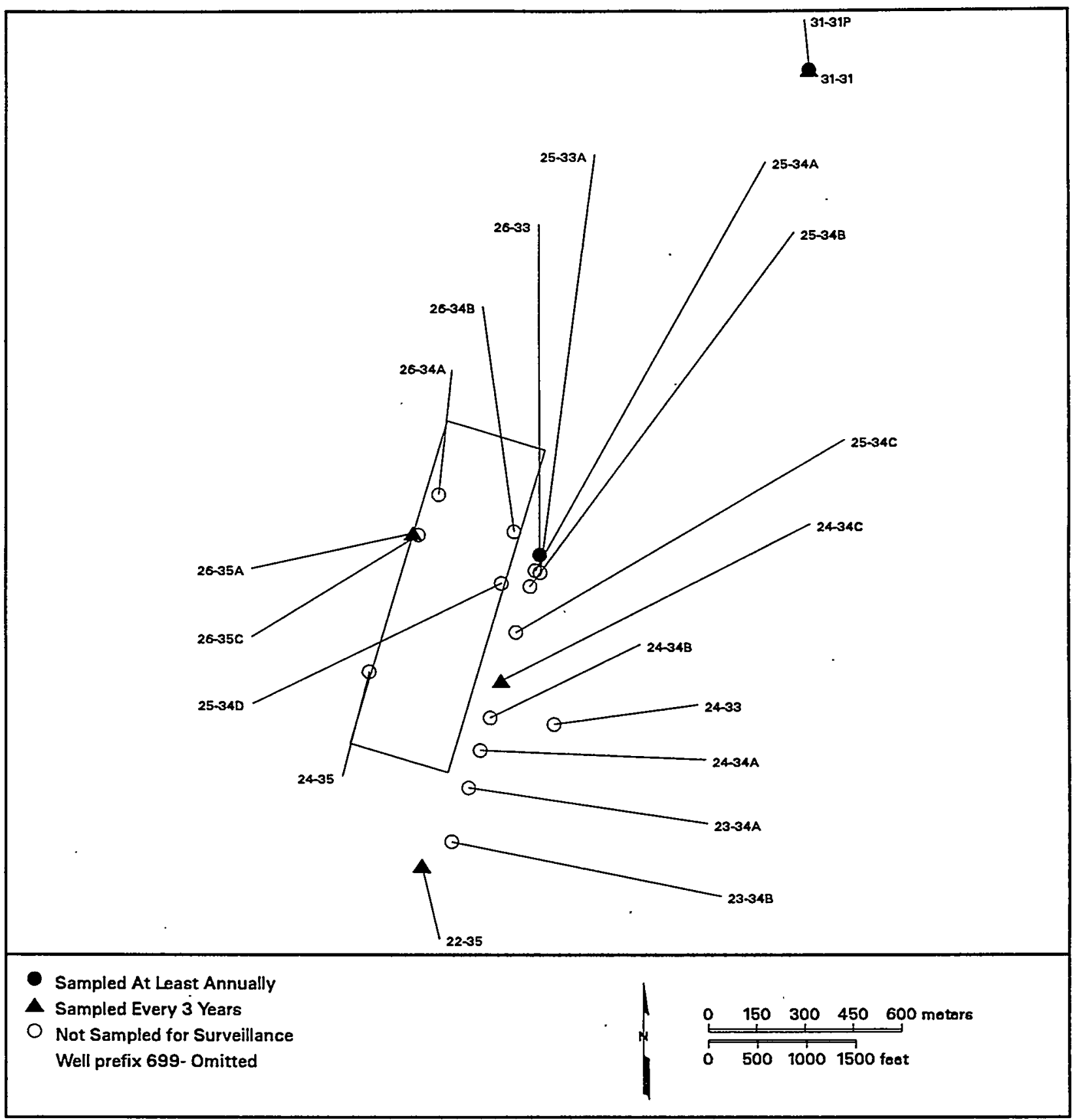

Can_hart_99017 Soptember 20,1999 2:04 PM

Figure 9.1. Groundwater Project Well Locations: Central Landfill Vicinity 


\subsection{Sampling and Analysis}

\subsection{Sampling}

Employees and subcontractors of Pacific Northwest National Laboratory sample wells for the groundwater project. Samplers follow their company's documented procedures for sampling, recordkeeping, field measurements, and sample shipment, consistent with Test Methods for Evaluating Solid Wastes: Physical/Chemical Methods, 3rd Edition (EPA 1986a). Water levels are measured, wells are purged of stagnant water, and samples are collected in prepared containers. Nearly all of the wells are equipped with pumps that are dedicated to a specific well. Most samples for metals are filtered in the field, and most other samples are unfiltered. Sample integrity is ensured through the use of chain-of-custody procedures.

\subsection{Analytical Methods}

Analytical methods used by the laboratories are described by Hartman (1999, Appendix C). Methods for chemical analysis of groundwater samples conform to Test Methods for Evaluating Solid Wastes: Physical/Chemical Methods, 3rd Edition (EPA 1986a); Methods for Chemical Analysis of Water and Wastes (EPA 1982), or other EPA methods; Annual Book of ASTM Standards (American Society for Testing and Materials 1986); and Standard Methods for the Examination of Water and Wastewater, 17th Edition (American Public Health Association 1989). The methods used for analysis of radiochemical constituents were developed by the analyzing laboratory and are recognized as acceptable within the technical radiochemical industry.

\subsection{Quality Assurance and Quality Control}

The quality assurance and quality control practices used by the groundwater project ensure the reliability and validity of field and laboratory measurements conducted to support these programs. The primary components used to assess data quality are accuracy, precision, and detection. Representativeness, completeness, and comparability may also be used. These parameters are evaluated through laboratory quality control checks (e.g., matrix spikes, laboratory blanks), replicate sampling and analysis, analysis of blind samples and blanks, and interlaboratory comparisons. Acceptance criteria have been established for each of these parameters. When a parameter is outside the criteria, corrective actions are taken to prevent a future occurrence. Quality control practices for the groundwater project are described in Hartman (1999, Appendix D).

Data are reviewed quarterly according to a Pacific Northwest National Laboratory procedure to ensure they are complete and representative. The review includes verification of the data in the Hanford Environmental Information System (HEIS) database, evaluation of data from field quality control samples (e.g., blanks, duplicates) and laboratory quality control samples, and a technical review by a scientist 
familiar with the hydrogeology of a particular location of the site. If the data review identifies suspect data, they are investigated to establish whether they reflect true conditions or an error, according to Pacific Northwest National Laboratory's "request for data review" procedure. Groundwater data associated with out-of-range quality control data or identified as suspect during the technical review are flagged in the database. 


\subsection{Water-Level Monitoring}

Water levels in the groundwater system are monitored on the Hanford Site primarily to help determine the direction and rate of groundwater flow. This information is used to interpret observed contaminant plume movements and to predict future plume movements. Other uses of water-level information include the identification of recharge and discharge areas, assessing the interaction between groundwater and surfacewater bodies, assessing the interaction between aquifers or hydrogeologic units, calibration of groundwater-flow models, and assessing the impact of liquid effluent-disposal practices on groundwater flow.

McDonald et al. (1999) provides a list of wells used for water-level measurements, criteria for their selection, hydrogeologic units monitored, and describes procedures used to collect the data. 


\subsection{Data Evaluation}

\subsection{Data Management}

Results of groundwater sampling and analysis are made accessible in the HEIS database. Analytical results from all Hanford Site groundwater-monitoring activities are stored in this common database, with the exception of some data collected for limited special projects that may not be directly comparable to standard data. The data are made available to federal and state regulators for retrieval.

The HEIS programmers and HEIS data owners, including the groundwater project, ensure database integrity and data consistency through membership in the onsite HEIS configuration control board and other ad hoc groups. The majority of data are loaded into the database from electronic files provided by the analytical laboratories. This minimizes data-entry errors and reduces the cost of data management.

As discussed in Section 10.3, a data validation and verification process results in flags and qualifiers based on quality control data and a technical review by a scientist. These flags are stored with the data in HEIS.

\subsection{Compliance Issues and Data Evaluation}

Data collected for the groundwater project are used to comply with a variety of requirements, including the Atomic Energy Act of 1954 (and associated DOE Orders), RCRA, CERCLA, and WAC permits. To comply with these requirements, data are compared with standards and subjected to statistical evaluations, as appropriate. The requirements and evaluation methods are listed in Table 12.1.

\subsection{Reporting}

Results of Hanford Site groundwater activities are reported annually (e.g., Hartman and Dresel 1998). That report presents contaminant-distribution maps, water-level maps, and concentration trend plots of contaminants and wells of interest; and meets the annual reporting requirements of RCRA and DOE Orders. CERCLA activities, including groundwater remediation and monitoring, are summarized.

Quarterly letter reports of RCRA data availability are submitted to the State of Washington Department of Ecology. Data from RCRA networks and the entire groundwater project are available on the HEIS database to the regulators. 
Table 12.1. Compliance Issues and Methods of Evaluation

\begin{tabular}{|l|l|}
\hline \multicolumn{1}{|c|}{ Requirement } & \multicolumn{1}{c|}{ Evaluation } \\
\hline DOE Order 5400.1 & $\begin{array}{l}\text { Compare groundwater concentrations to drinking water standards, derived } \\
\text { concentration guides, and historical trends. Produce maps of contaminant } \\
\text { distribution. }\end{array}$ \\
\hline RCRA interim-status units & $\begin{array}{l}\text { Indicator evaluation - Compare average downgradient concentrations of } \\
\text { indicator parameters to background critical mean values. } \\
\text { Assessment - Evaluate rate and extent of contamination (methods } \\
\text { described in site-specific monitoring plans). }\end{array}$ \\
\hline RCRA final-status units & $\begin{array}{l}\text { Detection - Compare downgradient concentrations of contaminants of } \\
\text { interest to baseline concentrations. } \\
\text { Compliance - Compare downgradient concentrations to background, } \\
\text { maximum concentration limits, or alternate concentration limits (methods } \\
\text { described in site-specific monitoring plans and site permit). } \\
\text { Corrective action - Track progress of cleanup and compare downgradient } \\
\text { concentrations of constituents to background, maximum concentration } \\
\text { limits, or alternate concentration limits (methods described in site-specific } \\
\text { monitoring plans and site permit). }\end{array}$ \\
\hline $\begin{array}{l}\text { WAC-permitted units } \\
\text { (216 permits) }\end{array}$ & \begin{tabular}{l} 
Compare to conditions of permit. \\
\hline CERCLA operable units
\end{tabular} \\
\hline $\begin{array}{l}\text { Performance assessment } \\
\text { monitoring }\end{array}$ & $\begin{array}{l}\text { Compare concentrations to levels defined in RODs, interim RODs, or } \\
\text { other agreements. }\end{array}$ \\
\hline
\end{tabular}

Certain conditions require reporting to DOE as unusual occurrences or off-normal events (DOE Order 232.1-1A). Those applicable to groundwater-monitoring results include the following:

- general environmental monitoring where data are greater than historical data or than expected of normal operations (off-normal occurrence)

- discovery of groundwater contamination resulting from DOE operations not part of an existing plume previously identified in either an annual report or in any CERCLA/RCRA activity or report (unusual occurrence).

Reporting requirements for WAC-permitted facilities are described in their permits. 


\subsection{References}

Airhart, S. P., J. V. Borghese, and S. Dudziak. 1990. Interim-Status Ground Water Monitoring Plan for the 216-S-10 Pond and Ditch. WHC-SD-EN-AP-018. Prepared by Pacific Northwest Laboratory for Westinghouse Hanford Company, Richland, Washington.

American Public.Health Association. 1989. Standard Methods for the Examination of Water and Wastewater, 17th Edition. New York.

American Society for Testing and Materials (ASTM). 1986. Annual Book of ASTM Standards. Philadelphia, Pennsylvania.

Atomic Energy Act of 1954, as amended, Ch. 1073, 68 Stat. 919, 42 USC 2011 et seq.

Barnett, D. B., J. S. Schmid, S. S. Lowe, W. L. Allen, N. A. Ballantyne, C. H. Dohrer, M. J. Hartman, F. N. Hodges, D. G. Horton, V. G. Johnson, K. J. Lueck, D. J. Ortiz, A. J. Knepp, B. H. Ford, S. P. Hope, D. K. Tyler, R. D. Hildebrand, D. E. Olson, R. E. Peterson, G. L. Kasza, D. A. Myers, S. P. Luttrell, P. D. Thorne, and K. R. Moser. 1995a. Hanford Site Ground-Water Protection Management Plan. DOE/RL-89-12, Rev. 2. U.S. Department of Energy, Richland Operations Office, Richland, Washington.

Barnett, D. B., J. D. Davis, L. B. Collard, P. B. Freeman, and C. J. Chou. 1995b. Groundwater Screening Evaluation/Monitoring Plan - 200 Area Treated Effluent Disposal Facility (Project W-049H). WHC-SD-EN-WP-012, Rev. 1. Westinghouse Hanford Company, Richland, Washington.

Bisping, L. E. 1996. Environmental Surveillance Master Sampling Schedule. PNNL-10950. Pacific Northwest National Laboratory, Richland, Washington.

Borghese, J. V., M. J. Hartman, S. P. Luttrell, C. J. Perkins, J. P. Boric, and S. C. Tidal. 1996. 100-N Pilot Project: Proposed Consolidated Groundwater Monitoring Program. HI-00725. Bechtel Hanford, Inc., Richland, Washington.

Caggiano, J. A. 1996a. Assessment Groundwater Monitoring Plan for Single-Shell Tank Waste Management Area S-SX. WHC-SD-EN-AP-191. Westinghouse Hanford Company, Richland, Washington.

Caggiano, J. A. 1996b. Assessment Groundwater Monitoring Plan for Single-Shell Tank Waste Management Area $B-B X-B Y$. WHC-SD-EN-AP-002. Westinghouse Hanford Company, Richland, Washington.

Caggiano, J. A., and C. J. Chou. 1993. Interim-Status Groundwater Quality Assessment Plan for the Single-Shell Tank Waste Management Areas T and TX-TY. WHC-SD-EN-AP-132. Westinghouse Hanford Company, Richland, Washington.

Caggiano, J. A., and S. M. Goodwin. 1991. Interim-Status Groundwater Monitoring Plan for the SingleShell Tanks. WHC-SD-EN-AP-012, Rev. 1. Westinghouse Hanford Company, Richland, Washington. 
Comprehensive Environmental Response, Compensation, and Liability Act of 1980, as amended, Public Law 96-510, 94 Stat. 2767, 42 USC 9601 et seq.

Davis, J. D., D. B. Barnett, C. J. Chou, and P. B. Freeman. 1996. Ground-Water Screening Evaluation/ Monitoring Plan-200 Area Effluent Treatment Facility (Project C-018H). WHC-SD-C018H-PLN-004, Rev. 1. Westinghouse Hanford Company, Richland, Washington.

DOE - See U.S. Department of Energy.

EPA - See U.S. Environmental Protection Agency.

Evans, J. C. 1989. 1100-EM-1 Soil Gas Survey Final Report. WHC-MR-0072. Westinghouse Hanford Company, Richland, Washington.

Ford, B. H. 1996. Description of Work for Routine Groundwater Sampling at the Environmental Restoration Disposal Facility. BHI-00873. Bechtel Hanford, Inc., Richland, Washington.

Freeman-Pollard, J. R. 1996. 200-ZP-1 IRM Phase II and III Remedial Design Report. DOE/RL-96-07, Rev. 1. U.S. Department of Energy, Richland Operations Office, Richland, Washington.

Hartman, M. J. 1991. Groundwater Monitoring Plan for the 100-D Ponds. WHC-SD-EN-AP-048. Westinghouse Hanford Company, Richland, Washington.

Hartman, M. J. 1996. Groundwater Monitoring Plan for the 1301-N, 1325-N, and 1324-N/NA Sites. WHC-SD-EN-AP-038, Rev. 2. Westinghouse Hanford Company, Richland, Washington.

Hartman, M. J. 1997. Groundwater Monitoring Plan for the 183-H Solar Evaporation Basins.

PNNL-11573. Pacific Northwest National Laboratory, Richland, Washington.

Hartman, M. J., and Dresel P. E. (eds.). 1998. Hanford Site Groundwater Monitoring for Fiscal Year 1997. PNNL-11793. Pacific Northwest National Laboratory, Richland, Washington.

Hartman, M. J. (ed). 1999. Hanford Site Groundwater Monitoring for Fiscal Year 1998. PNNL-12086, Pacific Northwest National Laboratory, Richland, Washington.

Hodges, F. N. 1993. Groundwater Monitoring Plan for the Solid Waste Landfill, Hanford, Washington. WHC-SD-EN-AP-043. Westinghouse Hanford Company, Richland, Washington.

Jensen, E. J., M. A. Chamness, S. M. Goodwin, S. H. Hall, and D. R. Newcomer. 1990. Interim-Status Ground-Water Monitoring Plan for the 216-U-12 Crib. WHC-SD-EN-AP-019. Prepared by Pacific Northwest Laboratory for Westinghouse Hanford Company, Richland, Washington. 
Johnson, V. G., C. J. Chou, and J. W. Lindberg. 1995. Groundwater Monitoring and Assessment Plan for the 100-K Area Fuel Storage Basins. WHC-SD-EN-AP-174. Westinghouse Hanford Company, Richland, Washington.

Kasza, G. L., and S. M. Goodwin. 1991. Groundwater Monitoring Plan for the 216-A-29 Ditch. WHC-SD-EN-AP-045, Rev. 0-A. Westinghouse Hanford Company, Richland, Washington.

Last, G. V., and B. N. Bjornstad. 1989. Revised Ground-Water Monitoring Plan for the 200 Areas LowLevel Burial Grounds. WHC-SD-EN-AP-015. Prepared by Pacific Northwest Laboratory for Westinghouse Hanford Company, Richland, Washington.

Lindberg, J. W. 1997. Combination RCRA Groundwater Monitoring Plan for the 216-A-10, 216-A-36B, and 216-A-37-1 PUREX Cribs. PNNL-11523. Pacific Northwest National Laboratory, Richland, Washington.

Lindberg, J. W., and F. W. Bond. 1979. Geohydrology and Ground-Water Quality Beneath the 300 Area, Hanford Site, Washington. PNL-2949. Pacific Northwest Laboratory, Richland, Washington.

Lindberg, J. W., and M. J. Hartman. 1999. Groundwater Monitoring Plan for the Nonradioactive Dangerous Waste Landfill. PNNL-12227. Pacific Northwest National Laboratory, Richland, Washington.

Lindberg, J. W., C. J. Chou, and V. G. Johnson. 1995. Groundwater Monitoring Plan for the 300 Area Process Trenches. WHC-SD-EN-AP-185. Westinghouse Hanford Company, Richland, Washington.

Lindsey, K. A. 1995. Miocene- to Pliocene-Aged Suprabasalt Sediments of the Hanford Site, SouthCentral Washington. BHI-00184. Bechtel Hanford, Inc., Richland, Washington.

McDonald, J. P., M. A. Chamness, and D. R. Newcomer. 1999. Water-Level Monitoring Plan for the Hanford Groundwater Monitoring Project. PNNL-13021. Pacific Northwest National Laboratory, Richland, Washington.

Peterson, R. E., and R. F. Raidl. 1996. Groundwater Monitoring Implementation Plan for the 100-BC-5, 100-KR-4, 100-HR-3, and 100-FR-3 Operable Units. BHI-00916. Prepared by CH2M Hill Hanford, Inc. for Bechtel Hanford, Inc., Richland, Washington.

Record of Decision (ROD). 1993. Record of Decision, USDOE Hanford 1100 Area, Hanford Site, Richland, Washington (1100-EM-1, 1100-EM-2, 1100-EM-3 and 1100-IU-1 Operable Units). State of Washington Department of Ecology, U.S. Environmental Protection Agency, and U.S. Department of Energy, Richland Operations Office, Richland, Washington.

Record of Decision (ROD). 1996a. Declaration of the Record of Decision, USDOE Hanford 100 Area, 100-HR-3 and 100-KR-4 Operable Units, Hanford Site, Benton County, Washington, April 1996. State of Washington Department of Ecology, U.S. Environmental Protection Agency, and U.S. Department of Energy, Richland Operations Office, Richland, Washington. 
Record of Decision (ROD). 1996b. Declaration of the Record of Decision for the 300-FF-I and 300-FF-5 Operable Units. State of Washington Department of Ecology, U.S. Environmental Protection Agency, and U.S. Department of Energy, Richland Operations Office, Richland, Washington.

Record of Decision (ROD). 1997. Declaration of the Record of Decision, U.S. DOE Hanford 200 Area, Hanford Site, Benton County, Washington (200-UP-1). State of Washington Department of Ecology, U.S. Environmental Protection Agency, and U.S. Department of Energy, Richland Operations Office, Richland, Washington.

Resource Conservation and Recovery Act of 1976, as amended, Public Law 94-580, 90 Stat. 2795, 42 USC 6901 et seq.

Revised Code of Washington, Title 70, Chapter 105, Hazardous Waste Management.

Schalla, R., R. L. Aaberg, D. J. Bates, J.V.M. Carlile, M. D. Freshley, T. L. Liikala, P. J. Mitchell, K. B. Olsen, and J. T. Rieger. 1988. Revised Ground-Water Monitoring Compliance Plan for the 300 Area Process Trenches. PNL-6671. Pacific Northwest Laboratory, Richland, Washington

Schmid, J. S. 1990. Interim Status Groundwater Monitoring Plan for the 200 East Area Liquid Effluent Retention Facility. WHC-SD-EN-AP-024. Westinghouse Hanford Company, Richland, Washington.

Siemens Power Corporation. 1996. Groundwater Quality Assessment Plan, Surface Impoundment System. EMF-96-194. Richland, Washington.

Siemens Power Corporation. 1997. 1996 Annual RCRA Report, Groundwater Quality Assessment Program. EMF-1933. Richland, Washington.

State of Washington Department of Ecology, U.S. Environmental Protection Agency, and U.S. Department of Energy. 1989. Hanford Federal Facility Agreement and Consent Order Between the U.S. Environmental Protection Agency, the U.S. Department of Energy, and the State of Washington Department of Ecology, May 15, 1989, as amended. Olympia, Seattle, and Richland, Washington.

Sweeney, M. D. 1995a. Interim-Status Groundwater Monitoring Plan for the 216-B-63 Trench. WHC-SD-EN-AP-165. Westinghouse Hanford Company, Richland, Washington.

Sweeney, M. D. 1995b. Interim-Status Groundwater Monitoring Plan for the 216-B-3 Pond System. WHC-SD-EN-AP-013, Rev. 1. Westinghouse Hanford Company, Richland, Washington.

Thorne, P. D., M. A. Chamness, F. A. Spane, Jr., V. R. Vermeul, and W. D. Webber. 1993. ThreeDimensional Conceptual Model for the Hanford Site Unconfined Aquifer System, FY 93 Status Report. PNL-8971. Pacific Northwest Laboratory, Richland, Washington.

U.S. Department of Energy (DOE). 1990. Phase I Remedial Investigation Report for the Hanford Site 1100-EM-1 Operable Unit. DOE/RL-90-18. Richland Operations Office, Richland, Washington. 
U.S. Department of Energy (DOE). 1992. Final Remedial Investigation Study - Environmental Assessment Report for the 1100-EM-1 Operable Unit, Hanford. DOE/RL-92-67, Draft B. Richland Operations Office, Richland, Washington.

U.S. Department of Energy (DOE). 1995a. Hanford Sitewide Groundwater Remediation Strategy. DOE/RL-94-95, Rev. 1. Richland Operations Office, Richland, Washington.

U.S. Department of Energy (DOE). 1995b. 200-BP-5 Operable Unit Treatability Test Report. DOE/RL-95-59. Richland Operations Office, Richland, Washington.

U.S. Department of Energy (DOE). 1995c. Additional Monitoring Well Installation and Field Sampling Plan for Continued Groundwater Monitoring at the Horn Rapids Landfill. DOE/RL-95-50. Prepared by the Department of the Army, Walla Walla District, Corps of Engineers, Walla Walla, Washington for the Richland Operations Office, Richland, Washington.

U.S. Department of Energy (DOE). 1996a. Interim Action Monitoring Plan for the 100-HR-3 and 100-KR-4 Operable Units. DOE/RL-96-90, Draft A. Prepared by CH2M Hill Hanford, Inc. for Richland Operations Office, Richland, Washington.

U.S. Department of Energy (DOE). 1996b. 200-UP-1 Groundwater Remedial Design/Remedial Action Work Plan. DOE/RL-97-36, Rev. 2. Richland Operations Office, Richland, Washington.

U.S. Department of Energy (DOE). 1996c. RCRA Corrective Measure Study for the 200-PO-1 Operable Unit. DOE/RL-96-69. Richland Operations Office, Richland, Washington.

U.S. Department of Energy (DOE). 1996d. Operation and Maintenance Plan for the 300-FF-5 Operable Unit. DOE/RL-95-73. Richland Operations Office, Richland, Washington.

U.S. Department of Energy (DOE). 1996e. Limited Field Investigation Report for the 300-FF-2 Operable Unit. DOE/RL-96-42. Richland Operations Office, Richland, Washington.

U.S. Department of Energy (DOE). 1997. Environmental Monitoring Plan, United States Department of Energy, Richland Operations Office. DOE/RL-91-50, Rev. 2. Prepared by personnel from Pacific Northwest National Laboratory, Fluor Daniel Hanford, Inc., and its subcontractor Waste Management Federal Services of Hanford, Inc., and Bechtel Hanford, Inc. for U.S. Department of Energy, Richland Operations Office, Richland, Washington.

U.S. Department of Energy (DOE) Order 232.1. Occurrence Reporting and Processing of Operations Information. Washington, D.C.

U.S. Department of Energy (DOE) Order 5400.1. General Environmental Protection Program. Washington, D.C. 
U.S. Environmental Protection Agency (EPA). 1982. Methods for Chemical Analysis of Water and Wastes. EPA-600/4-82-055. Washington, D.C.

U.S. Environmental Protection Agency (EPA). 1986a. Test Methods for Evaluating Solid Wastes: Physical/Chemical Methods, 3rd Edition. SW-846. Office of Solid Waste and Emergency Response, Washington, D.C.

U.S. Environmental Protection Agency (EPA). 1986b. Resource Conservation and Recovery Act (RCRA) Groundwater Monitoring Technical Enforcement Guidance Document (TEGD).

OSWER-9950.1. Office of Solid Waste and Emergency Response, Washington, D.C.

Weeks, D. C., G. K. Jager, W. J. McMahon, and B. H. Ford. 1996. Groundwater Protection Plan for the Environmental Restoration Disposal Facility. BHI-00079. Bechtel Hanford, Inc., Richland, Washington.

Williams, B. A., and C. J. Chou. 1993. Interim-Status Groundwater Quality Assessment Plan for the 216-U-12 Crib. WHC-SD-EN-AP-103. Westinghouse Hanford Company, Richland, Washington. 


\section{Appendix A}

\section{Sampling Matrix for Hanford Groundwater Monitoring Project}




\section{Appendix A}

\section{Sampling Matrix for Hanford Groundwater Monitoring Project}

This appendix contains the integrated sampling and analysis matrix for the Hanford Groundwater Monitoring Project. The matrix was designed for use in fiscal year 2000, but also includes wells that will be sampled every 2 or 3 years (as discussed in Section 3.3 of the main text). The matrix includes well names, seeps, sampling frequency, and constituents to be monitored. Additional details, such as schedule, analytical methods, etc., reside in a project database. Wells sampled independently of the groundwater project (e.g., for assessment of pump-and-treat systems) are not included in this matrix.

The following is a description of the columns in the matrix.

WELL: Wells are listed numerically by digit; e.g., "1199" precedes "199" and "699-29-4" precedes "699-3-45." Wells with a 199- prefix are in reactor areas, 299- in 200 Areas, 399- in 300 Area, 499- in 400 Area, 699- in 600-Area, and 1199- in 1100 Area. For 699-xx-yy wells, xx and yy designate Hanford north and west coordinates in thousands of feet from an origin in the southern part of the site. Multiple listings indicate that a well is used for more than one monitoring requirement and data are shared among users. Proposed new wells are listed with temporary designations NEW-PROJ-\#. Seeps (shoreline springs), which are monitored in the reactor areas for the Comprehensive Environmental Response, Compensation, and Liability Act of 1980, are designated with the prefixes SB, SK, etc.

Most of the wells monitor the uppermost aquifer. Wells that monitor deeper units are noted in the OTHER/COMMENTS field. However, these designations are incomplete.

PROG (program): This column indicates the requirements the well is being sampled for. The following gives the full spellouts:

CERCLA = Comprehensive Environmental Response, Compensation, and Liability Act of 1980 .

$\mathrm{DOH}=$ State of Washington Department of Health

FFTF $=$ Fast Flux Test Facility (400 Area process ponds)

LTMC = Long-term monitoring, CERCLA (B,C, and F operable units)

RCRA $=$ Resource Conservation and Recovery Act of 1976

- SURV = sitewide surveillance (plume and trend tracking).

PROJ (project): This column gives the subsets of the programs listed above.

\begin{tabular}{|c|c|}
\hline Project Designation & Explanation \\
\hline $100 \mathrm{~B}$ & $\overline{100-B, C ~ A r e a ~}$ \\
\hline $100 \mathrm{BC} 5$ & 100-BC-5 Operable Unit \\
\hline 100D & 100-D Area \\
\hline
\end{tabular}


Project Designation

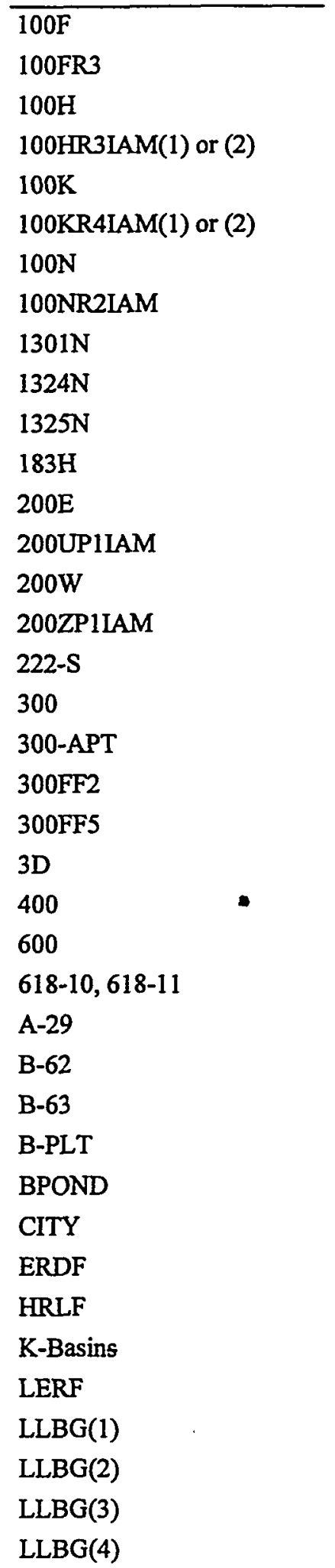

Explanation

100-F Area

100-FR-3 Operable Unit

100-H Area

100-HR-3 interim action monitoring

100-K Area

100-KR-4 interim action monitoring

100-N Area

100-NR-2 interim action monitoring

1301-N liquid waste-disposal facility

1324-N surface impoundment and 1324-NA percolation pond

1325-N liquid waste-disposal facility

183-H solar evaporation basins

200-East Area

200-UP-1 interim action monitoring

200-West Area

200-ZP-1 interim action monitoring

222-S Building

300 Area

300 Area process trenches (316-5)

300-FF-2 Operable Unit

300-FF-5 Operable Unit

Three-dimensional characterization (deeper well completion)

400 Area

600 Area

618-10 and 618-11 burial grounds

216-A-29 ditch

216-B-62 trench

216-B-63 trench

B Plant

216-B-3 pond

Surveillance monitoring of City of Richland well

Environmental Restoration Disposal Facility

Horn Rapids Landfill

100-K fuel-storage basins

Liquid effluent retention facility

Low-level burial grounds, waste management area 1

Low-level burial grounds, waste management area 2

Low-level burial grounds, waste management area 3

Low-level burial grounds, waste management area 4 


\begin{tabular}{|c|c|}
\hline Project Designation & Explanation \\
\hline$\overline{\mathrm{NRDW}}$ & Nonradioactive Dangerous Waste Landfill \\
\hline PUREX & Plutonium-Uranium Extraction Plant waste facilities \\
\hline REDOX & Reduction-oxidation project \\
\hline River & $\begin{array}{l}\text { Wells monitoring potential contamination near Columbia River } \\
\text { (see Chapter } 6.0 \text { in the main text) }\end{array}$ \\
\hline S-10 & $216-S-10$ pond and ditch \\
\hline $\operatorname{SST}(\mathrm{A})$ & Single-shell tanks, waste management area A-AX \\
\hline SST(B) & Single-shell tanks, waste management area B-BX-BY \\
\hline $\operatorname{SST}(\mathrm{C})$ & Single-shell tanks, waste management area $\mathrm{C}$ \\
\hline SST(S) or (SX) & Single-shell tanks, waste management area S-SX \\
\hline $\operatorname{SST}(\mathrm{T})$ & Single-shell tanks, waste management area $\mathrm{T}$ \\
\hline $\operatorname{SST}(\mathrm{TX} / \mathrm{TY})$ & Single-shell tanks, waste management area TX-TY \\
\hline SST(U) & Single-shell tanks, waste management area $U$ \\
\hline SWL & Solid Waste Landfill \\
\hline Transect & $\begin{array}{l}\text { Wells monitoring potential contamination out of } 200 \text { Areas (see } \\
\text { Chapter } 6.0 \text { in the main text) }\end{array}$ \\
\hline$U-1 / 2$ & $216-U-1$ and $216-U-2$ cribs \\
\hline $\mathrm{U}-12$ & 216-U-12 crib \\
\hline U-14 & 216-U-14 ditch \\
\hline U-PLT & U Plant \\
\hline
\end{tabular}

FREQ (sampling frequency): The following are the definitions for this column

$2-\mathrm{xx}, 3-\mathrm{xx}=$ sampled every 2 or 3 years, beginning in fiscal year $2000(-00)$, $2001(-01)$, or $2002(-02)$

$\mathrm{A}=$ annually

$\mathrm{M}=$ monthly

$\mathrm{Q}=$ quarterly

$\mathrm{SA}=$ semiannually (twice each year).

Records with more than one.listed frequency are sampled for different constituents at different frequencies (e.g., "A/SA" is sampled semiannually for each constituent with a " 2 " in its column; annually for each constituent with a " 1 " in its column). The designation " $1 \mathrm{X} 4$ " indicates the number of replicates collected (in this case, four replicates are collected once per year).

The next 20 columns give the most commonly analyzed constituents. Some constituents may be analyzed by several methods; however, those details are not specified in this plan and are included in the project database. The following abbreviations are used:

$$
\begin{aligned}
\mathrm{I}-129 & =\text { iodine- } 129 \\
\mathrm{ICP} & =\text { metals by the inductively coupled-plasma method }
\end{aligned}
$$




$$
\begin{aligned}
\text { SR-90 } & =\text { strontium }-90 \text { (or strontium- } 89 \text { and }-90 \text { ) } \\
\text { TC-99 } & =\text { technetium-99 } \\
\text { TOC } & =\text { total organic carbon } \\
\text { TOX } & =\text { total organic halides } \\
\text { VOA } & =\text { volatile organic constituents. }
\end{aligned}
$$

Numbers in the constituent columns indicate the number of samples planned for the sample year (also see note under sampling frequency). Unfiltered and filtered samples for ICP metals are denoted U and F, respectively.

OTHER/COMMENTS: Metals are listed by their standard abbreviations, followed by "F" if filtered. Additional constituents are abbreviated as follows:

$$
\begin{aligned}
\text { Amm } & =\text { ammonium } \\
\mathrm{C} 14 & =\text { carbon- } 14 \\
\mathrm{COD} & =\text { chemical oxygen demand } \\
\mathrm{CN} & =\text { cyanide } \\
\text { col } & =\text { coliform bacteria } \\
\mathrm{DO} & =\text { dissolved oxygen } \\
\mathrm{O \& G} & =\text { oil and grease } \\
\mathrm{Pu}-\mathrm{iso} & =\text { isotopic plutonium } \\
\text { redox } & =\text { oxidation/reduction potential } \\
\mathrm{TDS} & =\text { total dissolved solids } \\
\mathrm{TPH} & =\text { total petroleum hydrocarbons } \\
\mathrm{U}-\mathrm{iso} & =\text { isotopic uranium } \\
\mathrm{SO} 4 & =\text { sulfate } \\
\mathrm{PCB} & =\text { polychlorinated biphenyls. }
\end{aligned}
$$

\section{NOTES:}

(a) At 300 Area Process Trenches, each semiannual sampling event comprises four independent samples collected at monthly intervals.

(b) Additional constituents: SeF, TIF, CN, Col, semivolatile organic constituents, dioxins and dibenzofurans, herbicides, pesticides, organophosphates, polychlorinated biphenyls, radium, sulfate.

(c) McDonald et al. (1999). 


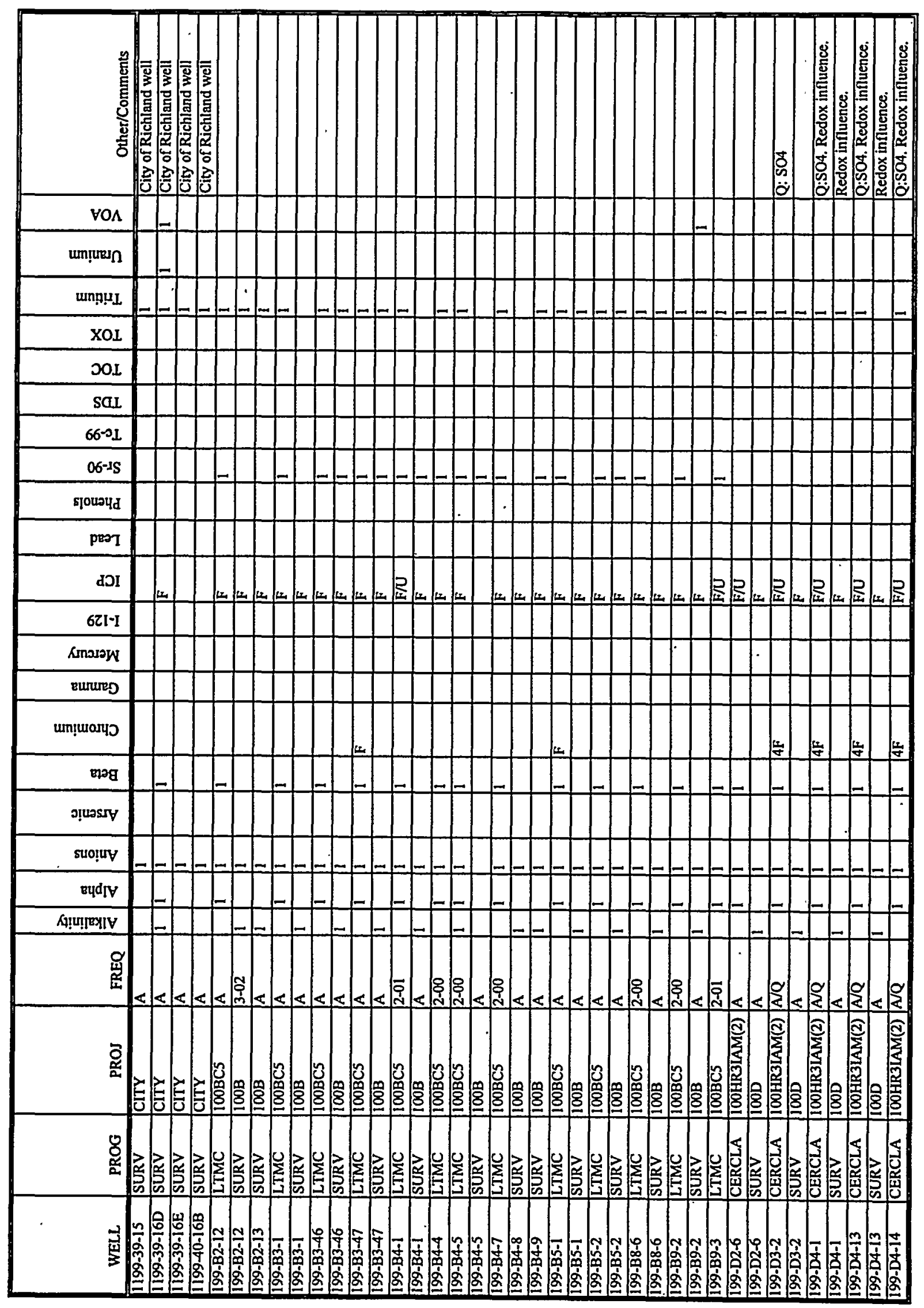




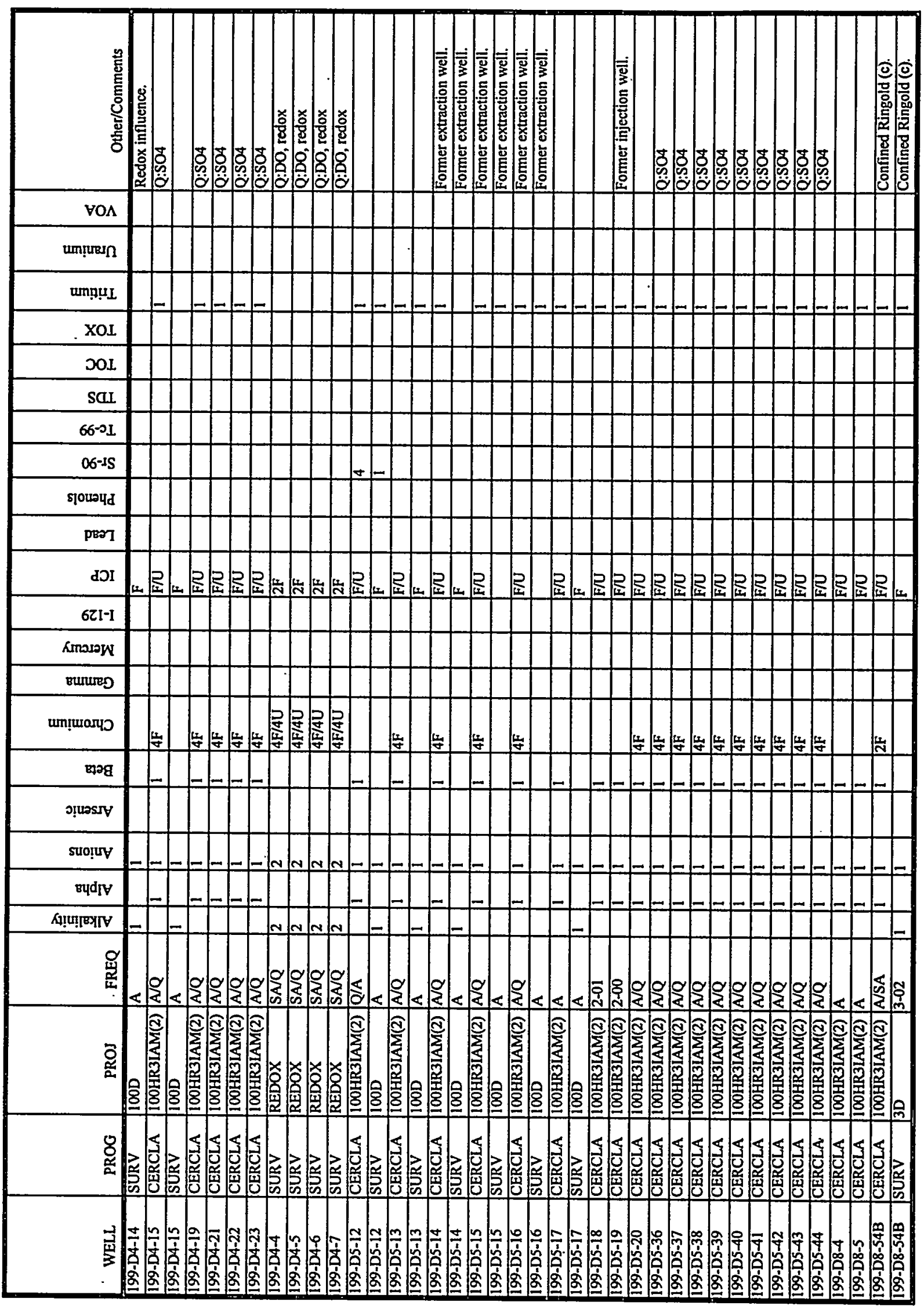




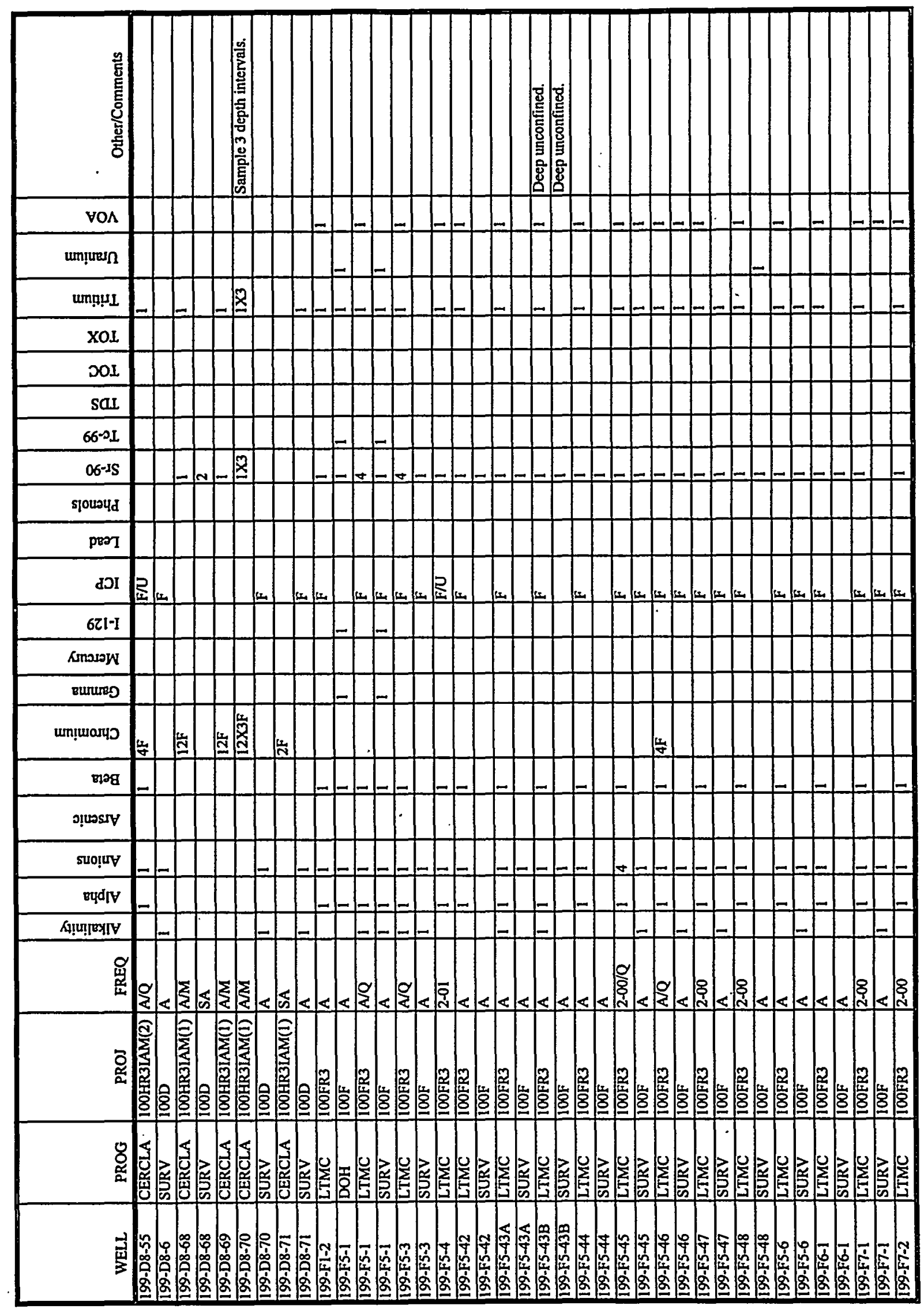




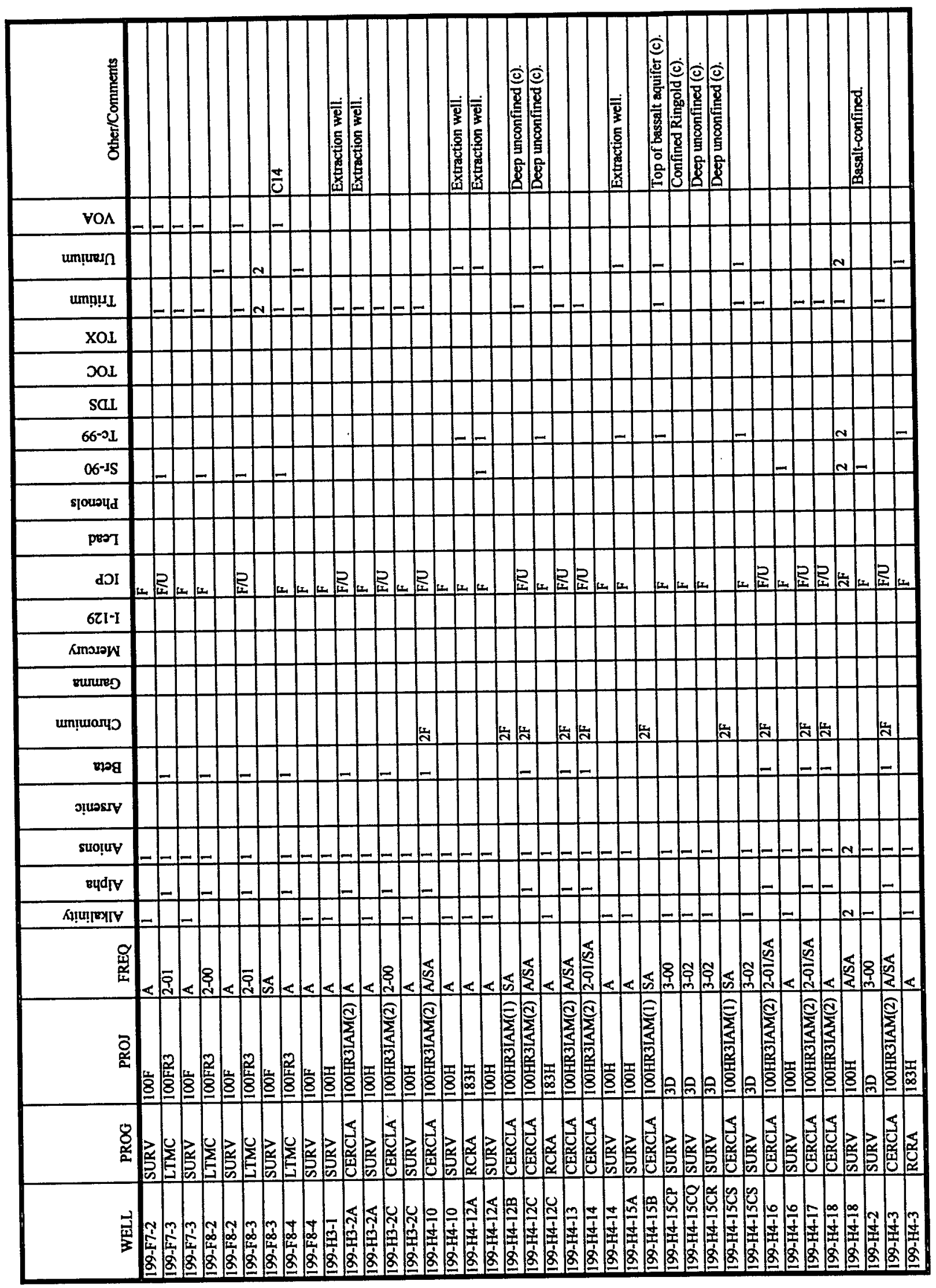




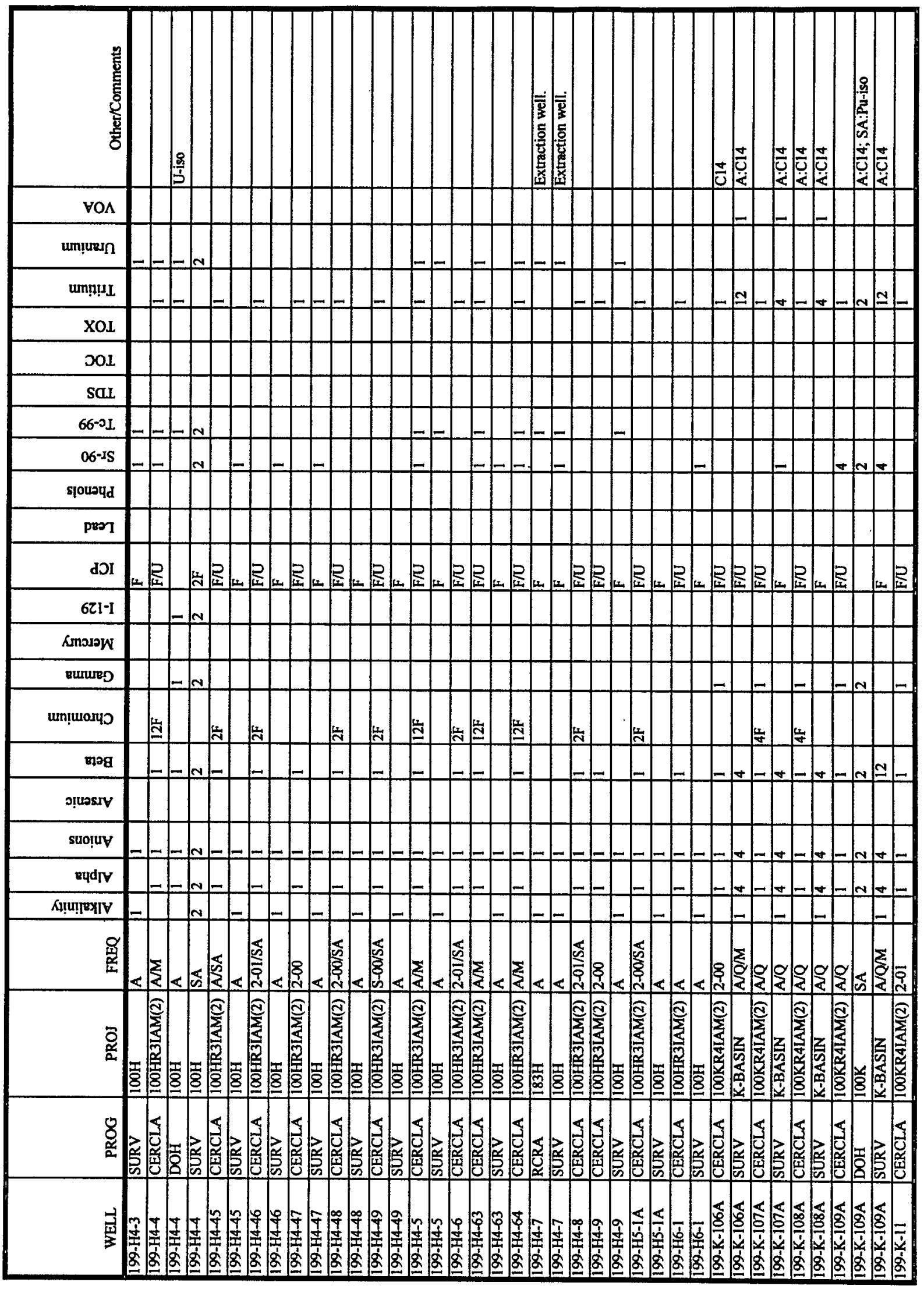




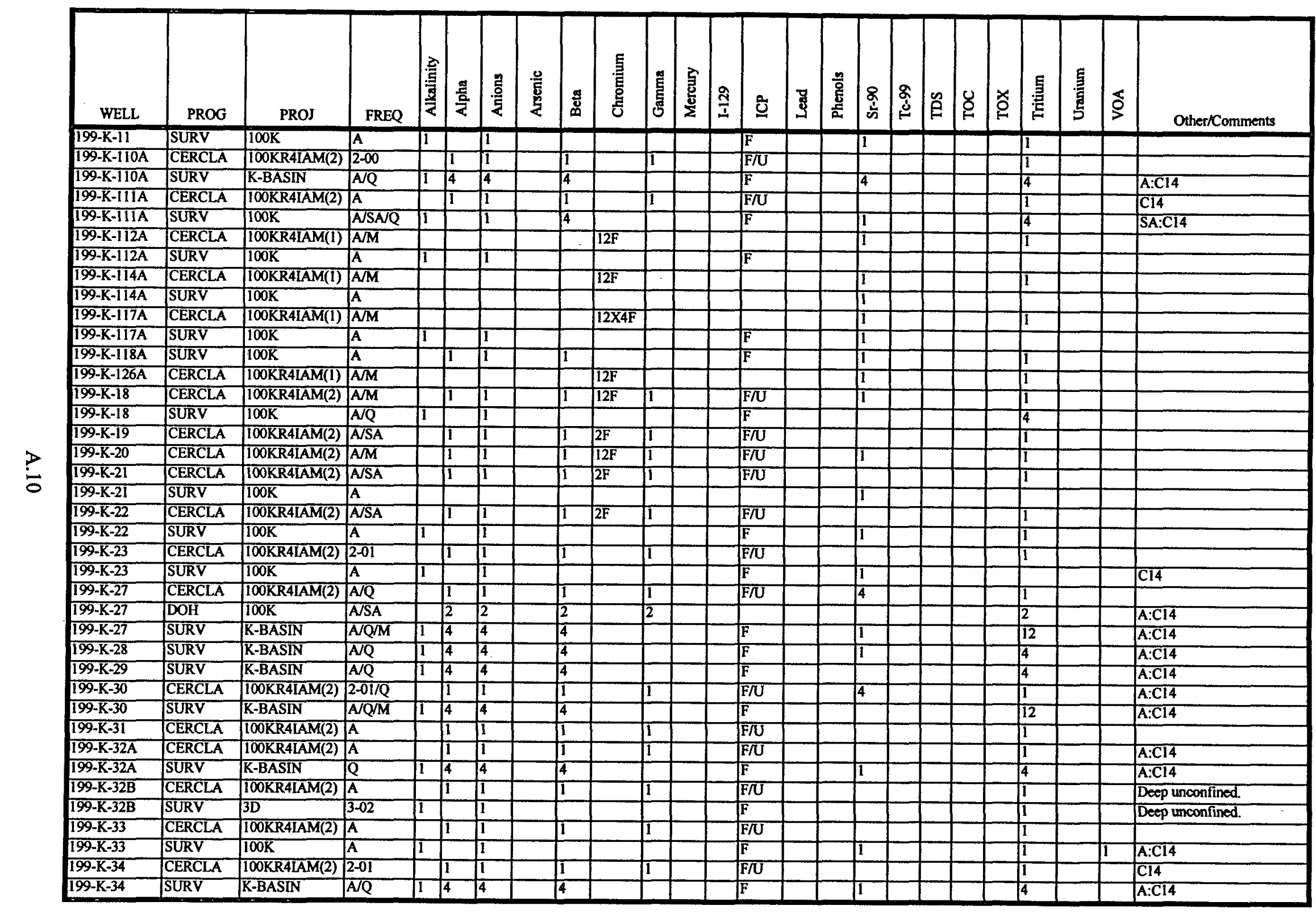




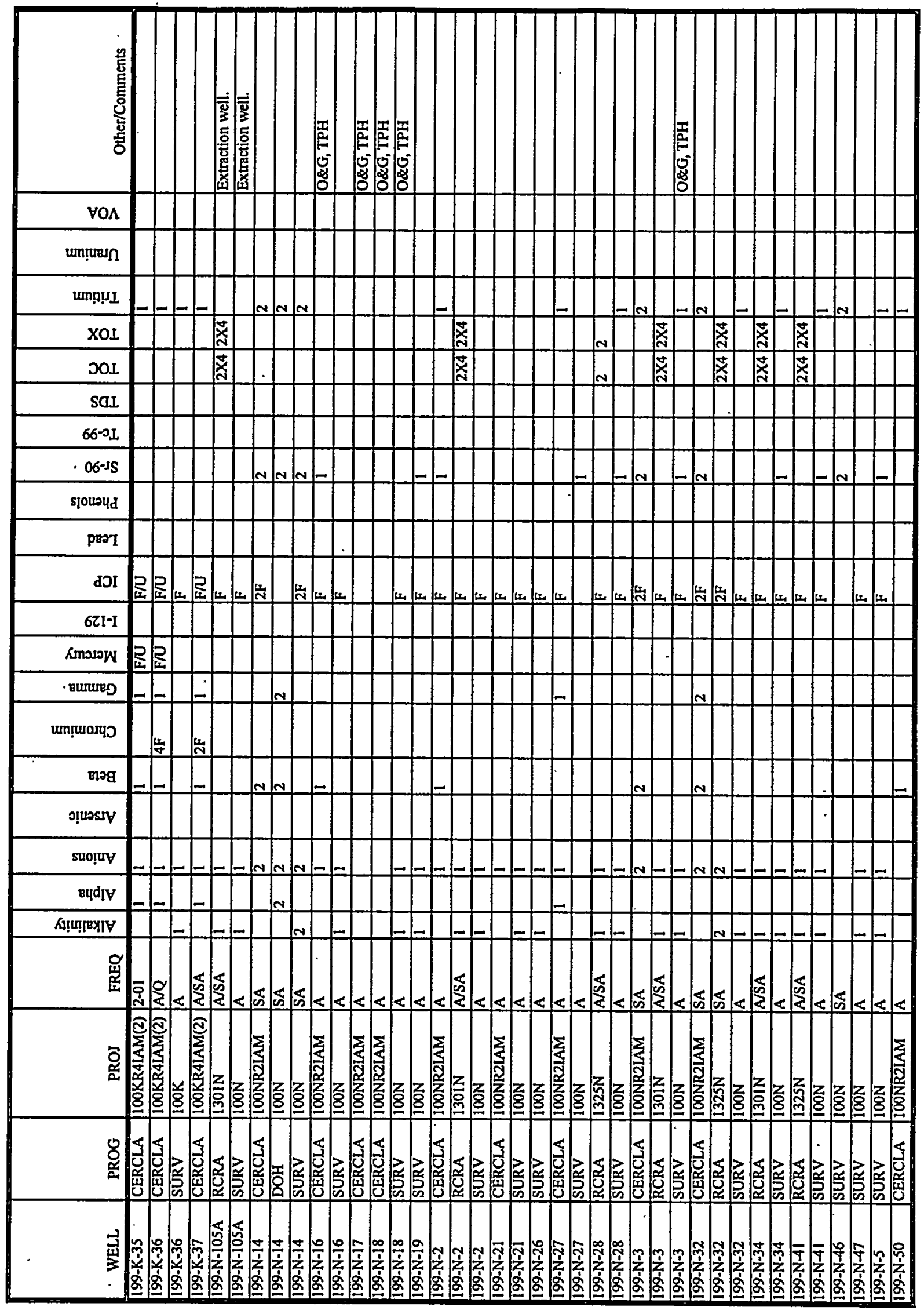

A.11 


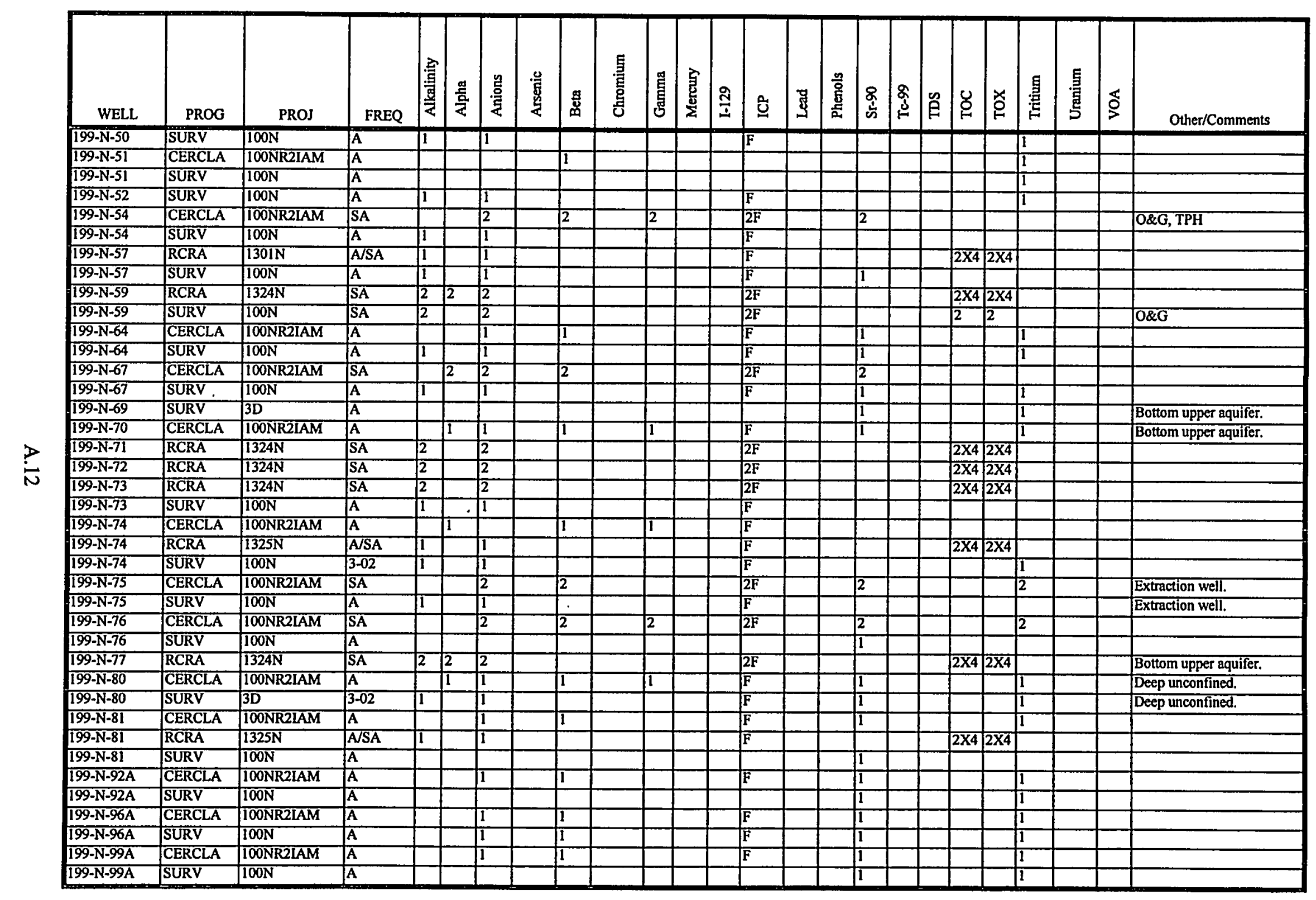




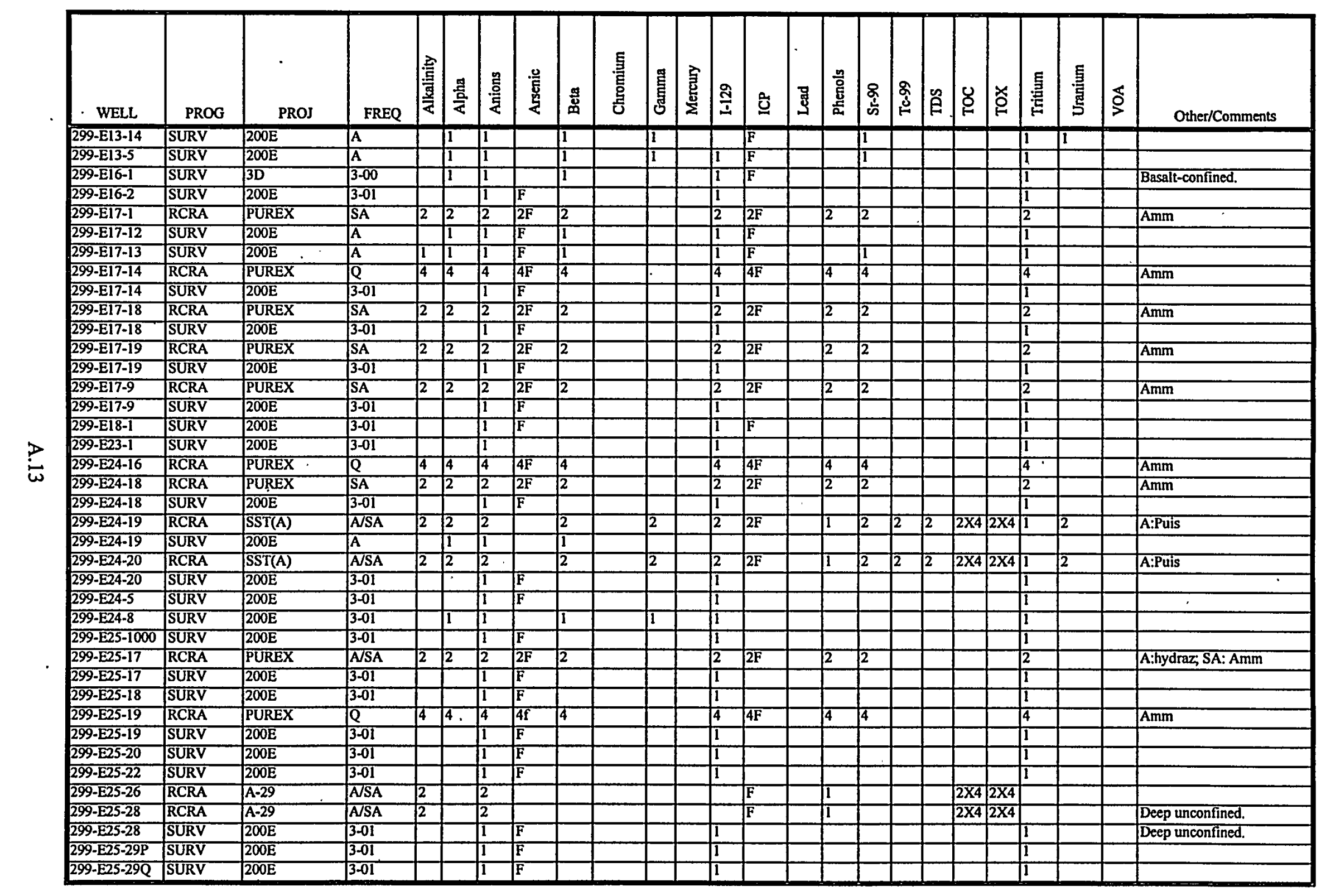




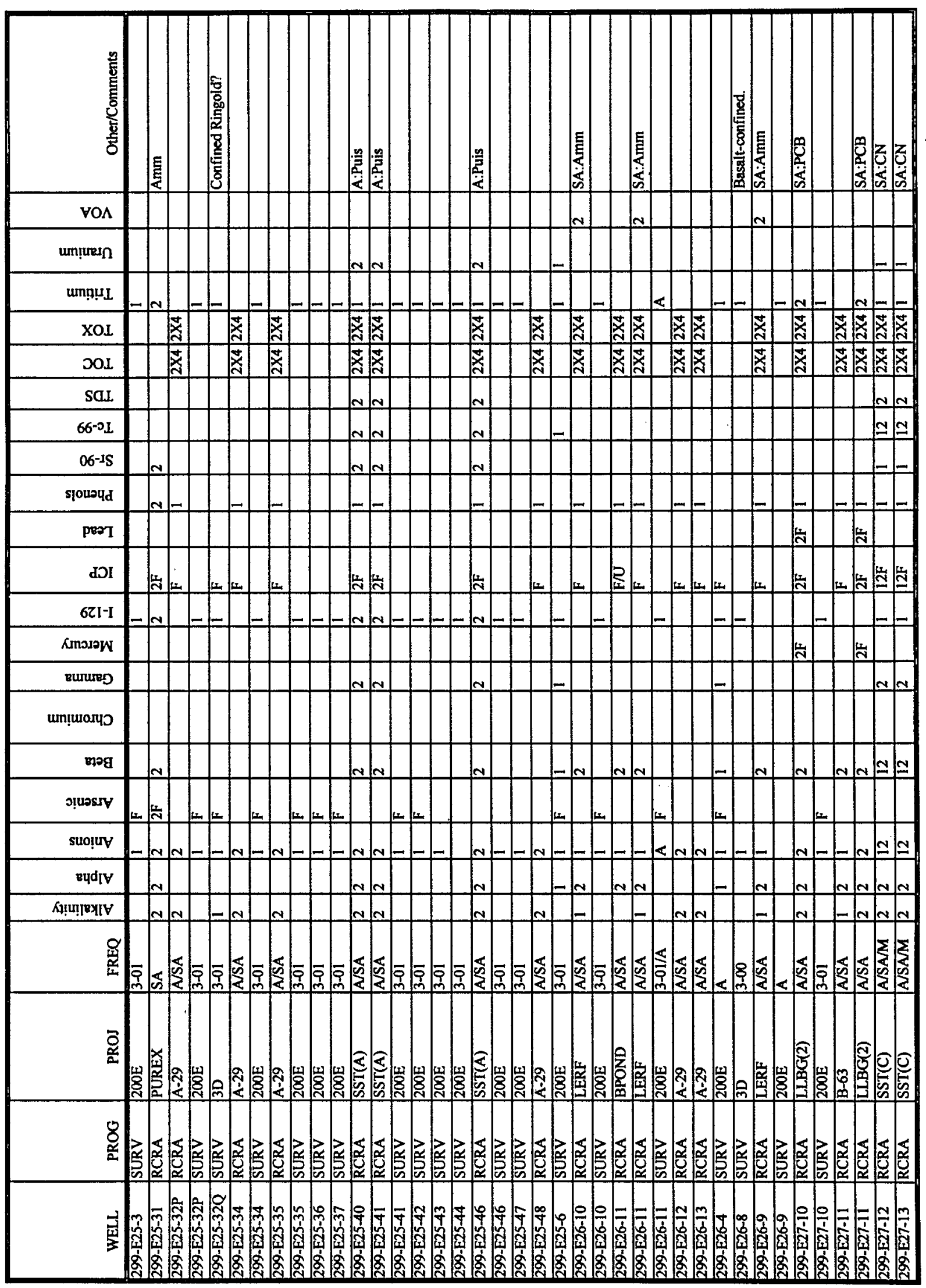

\section{A. 14}




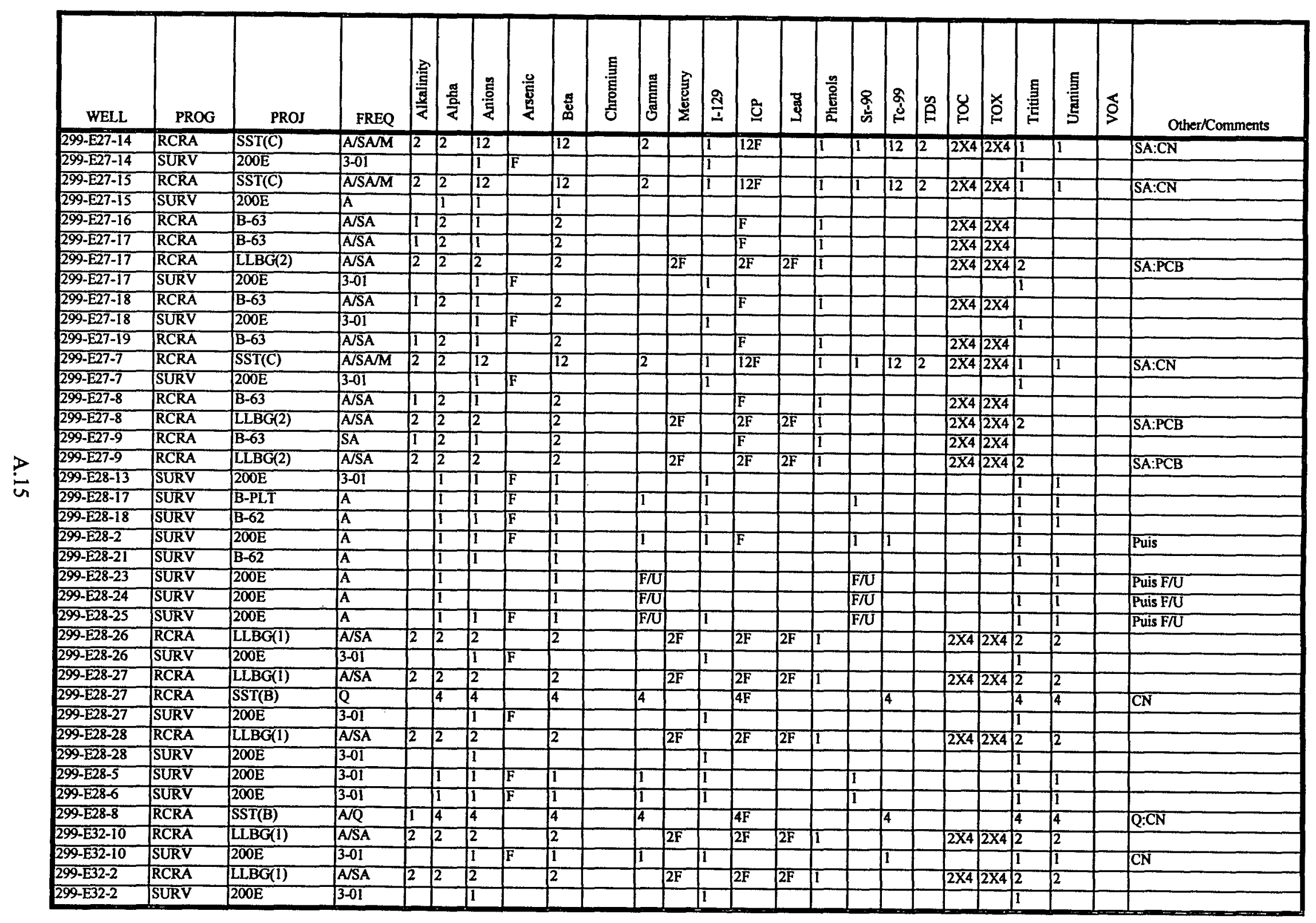




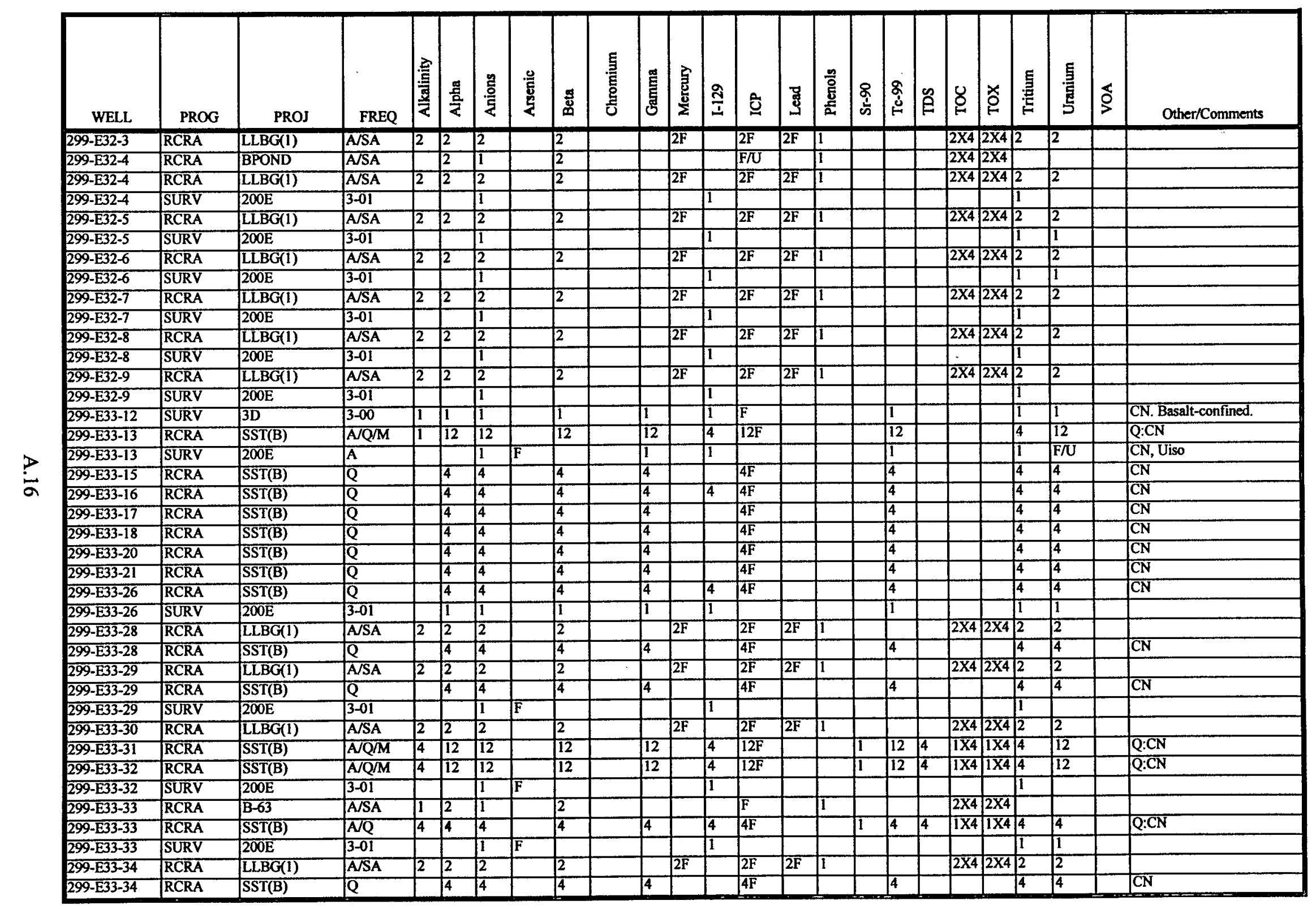




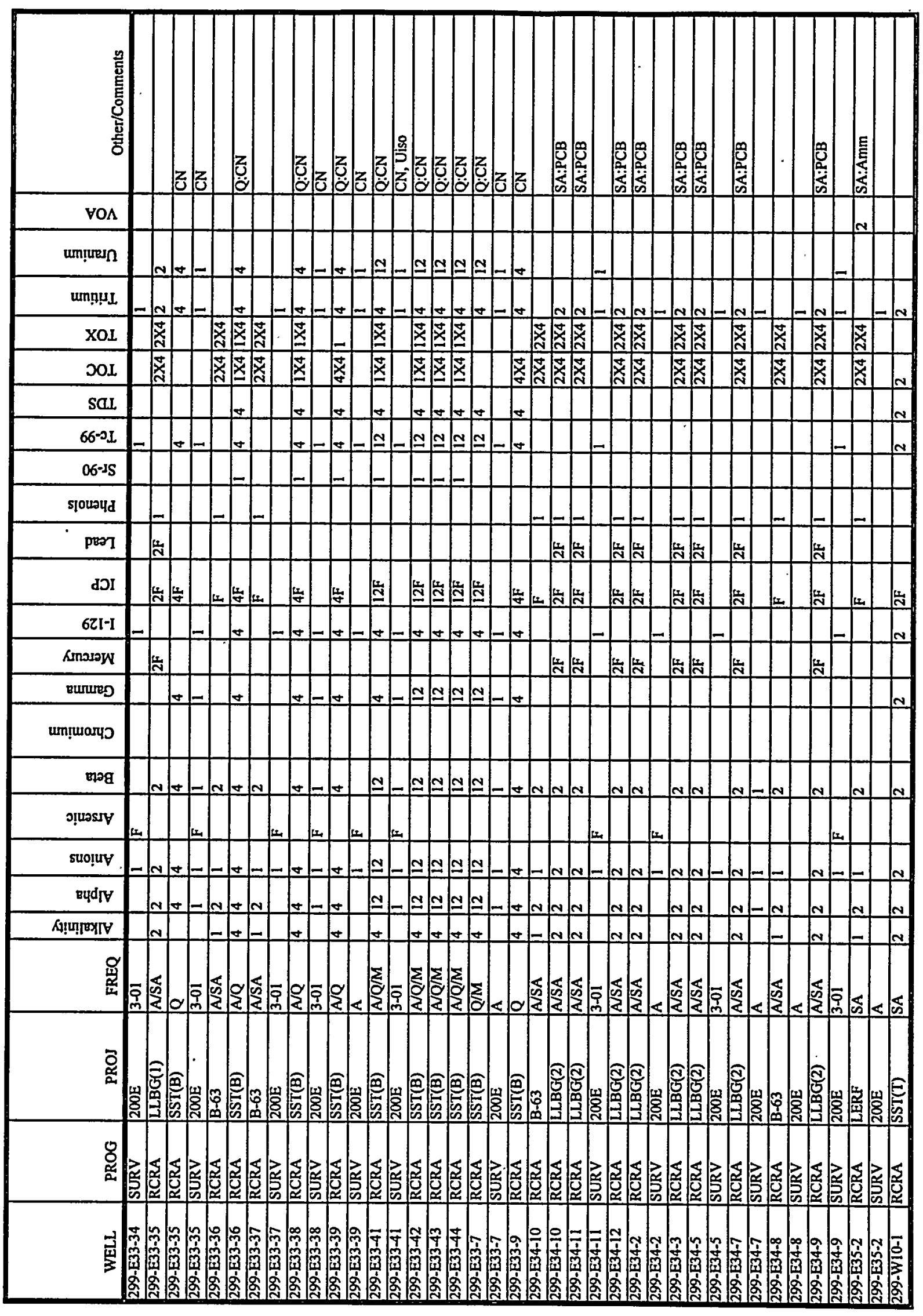




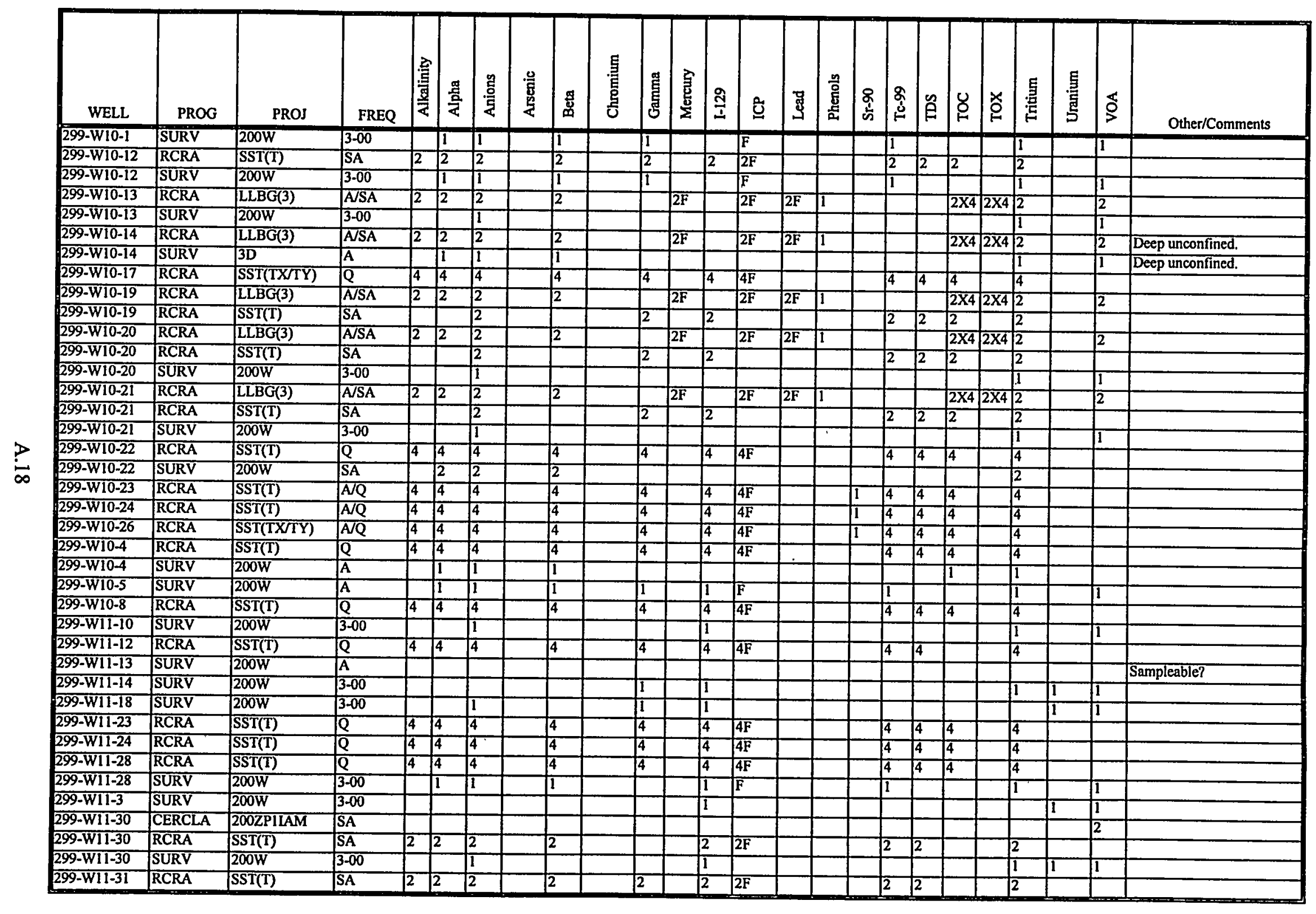




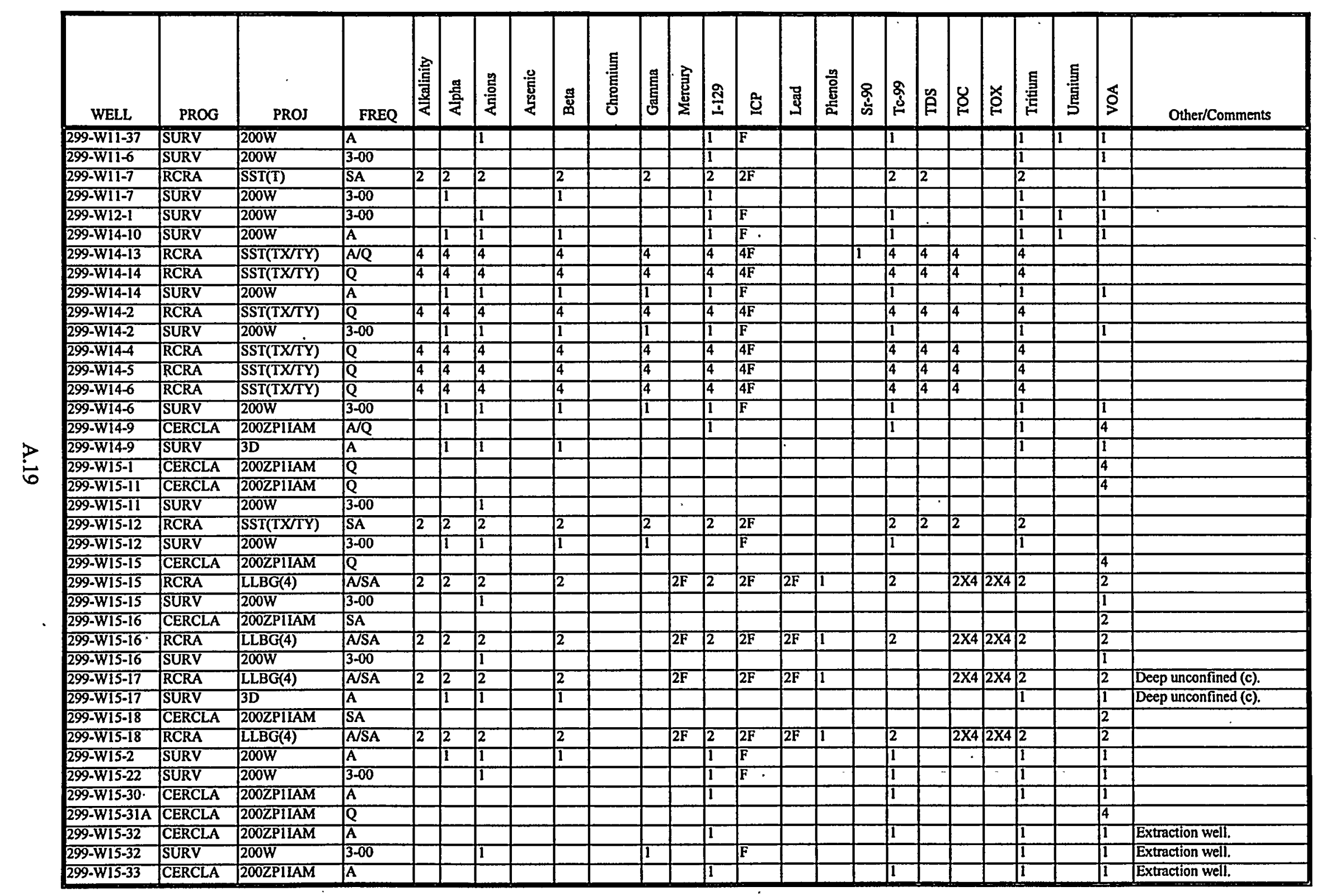




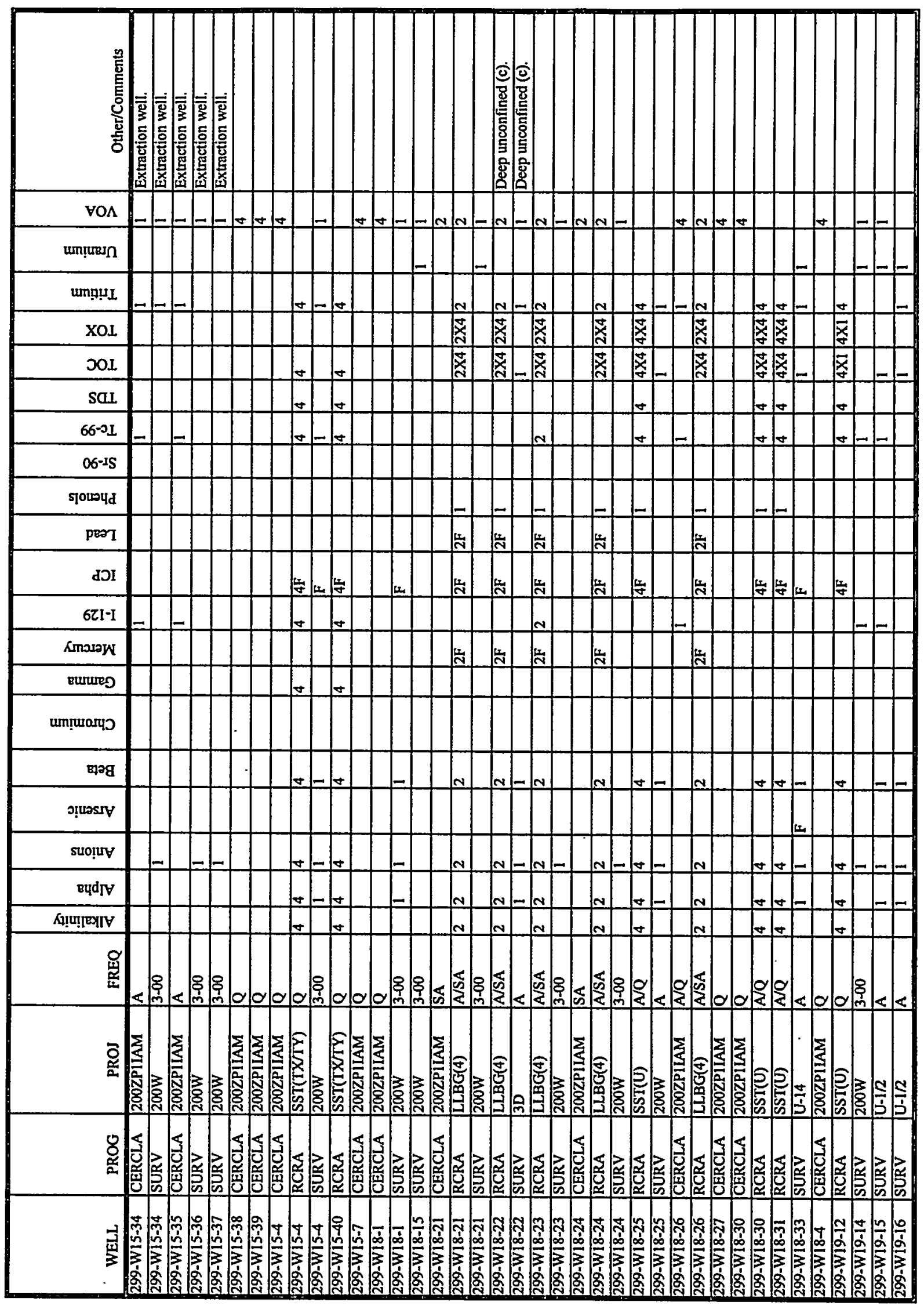




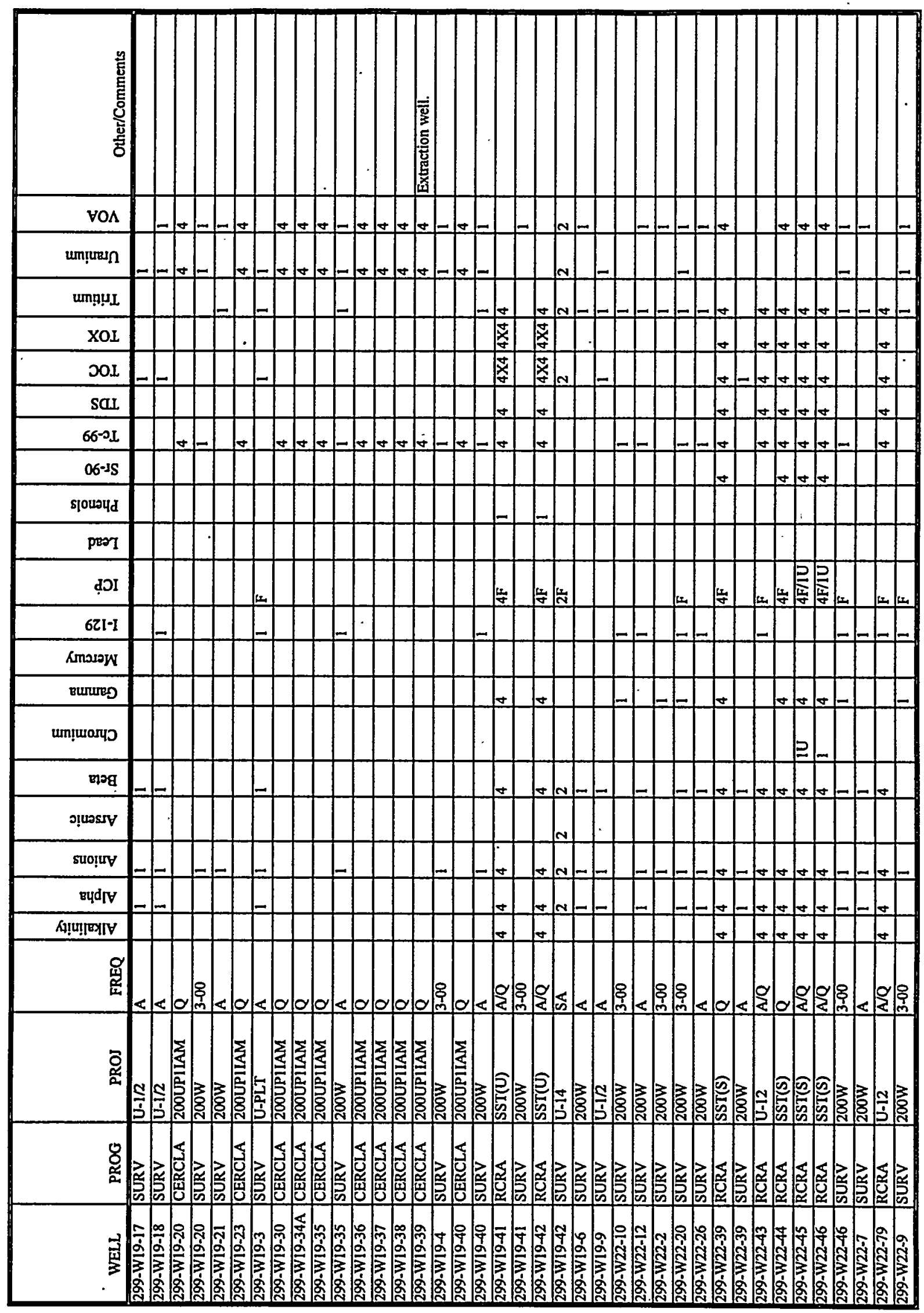




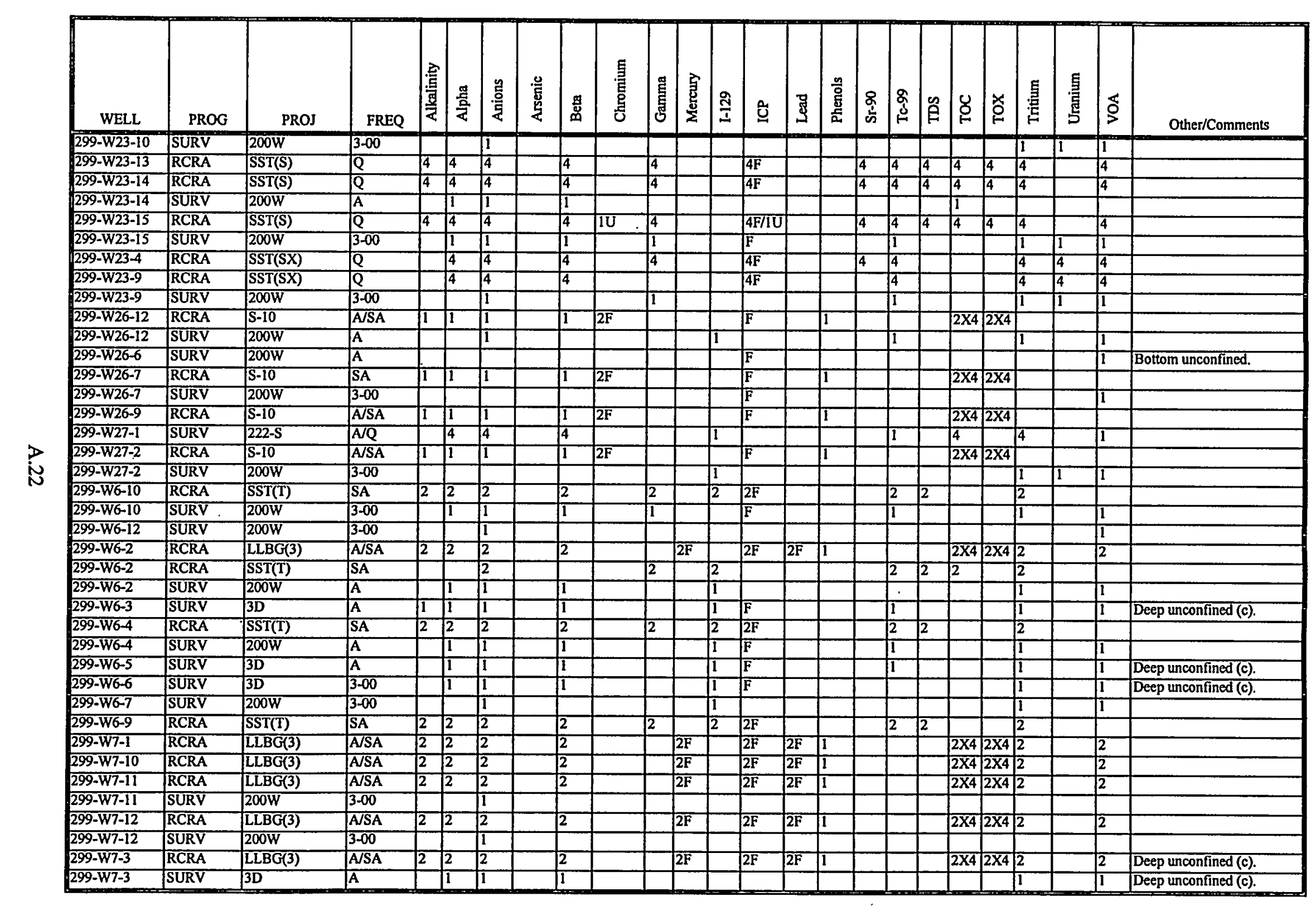




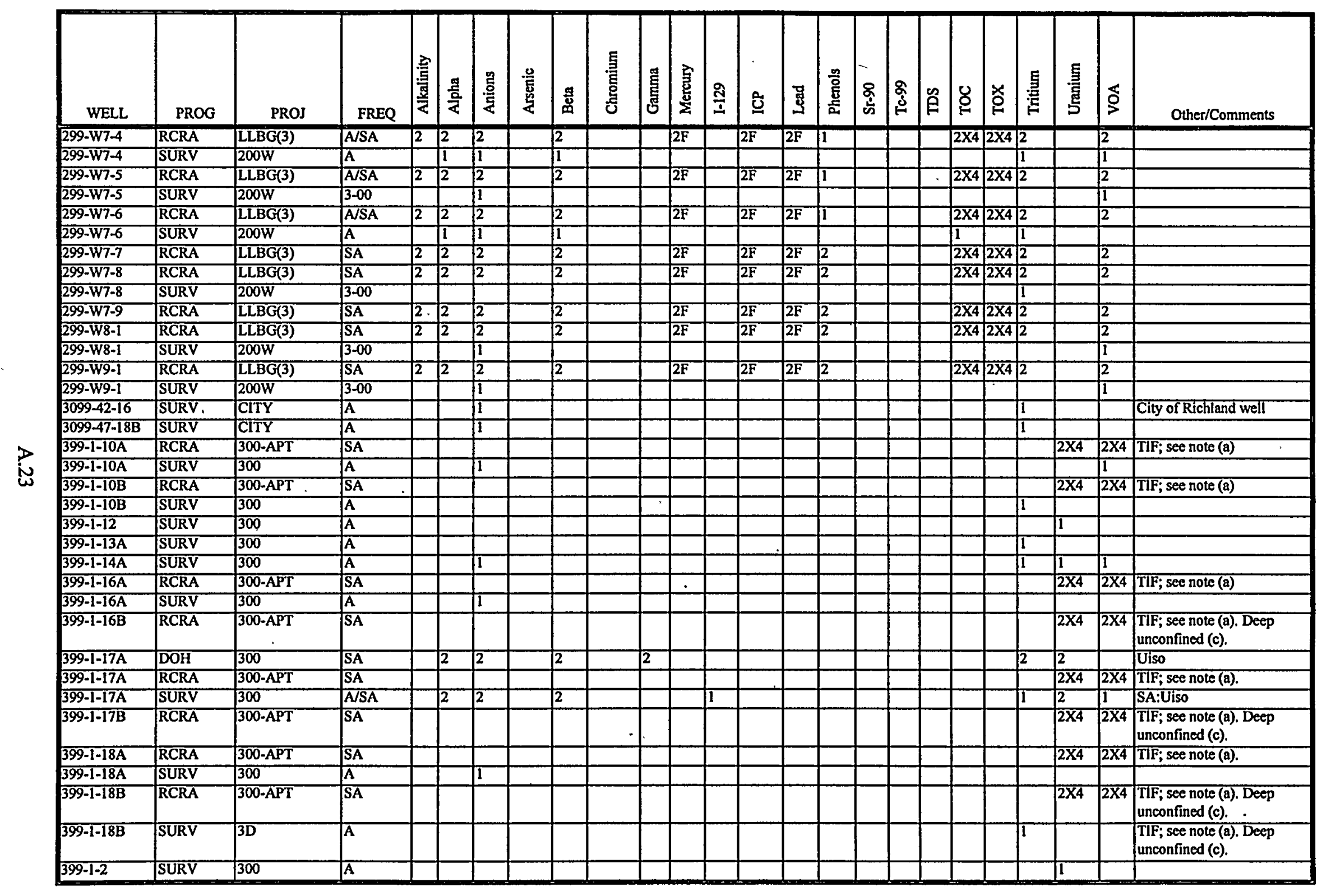




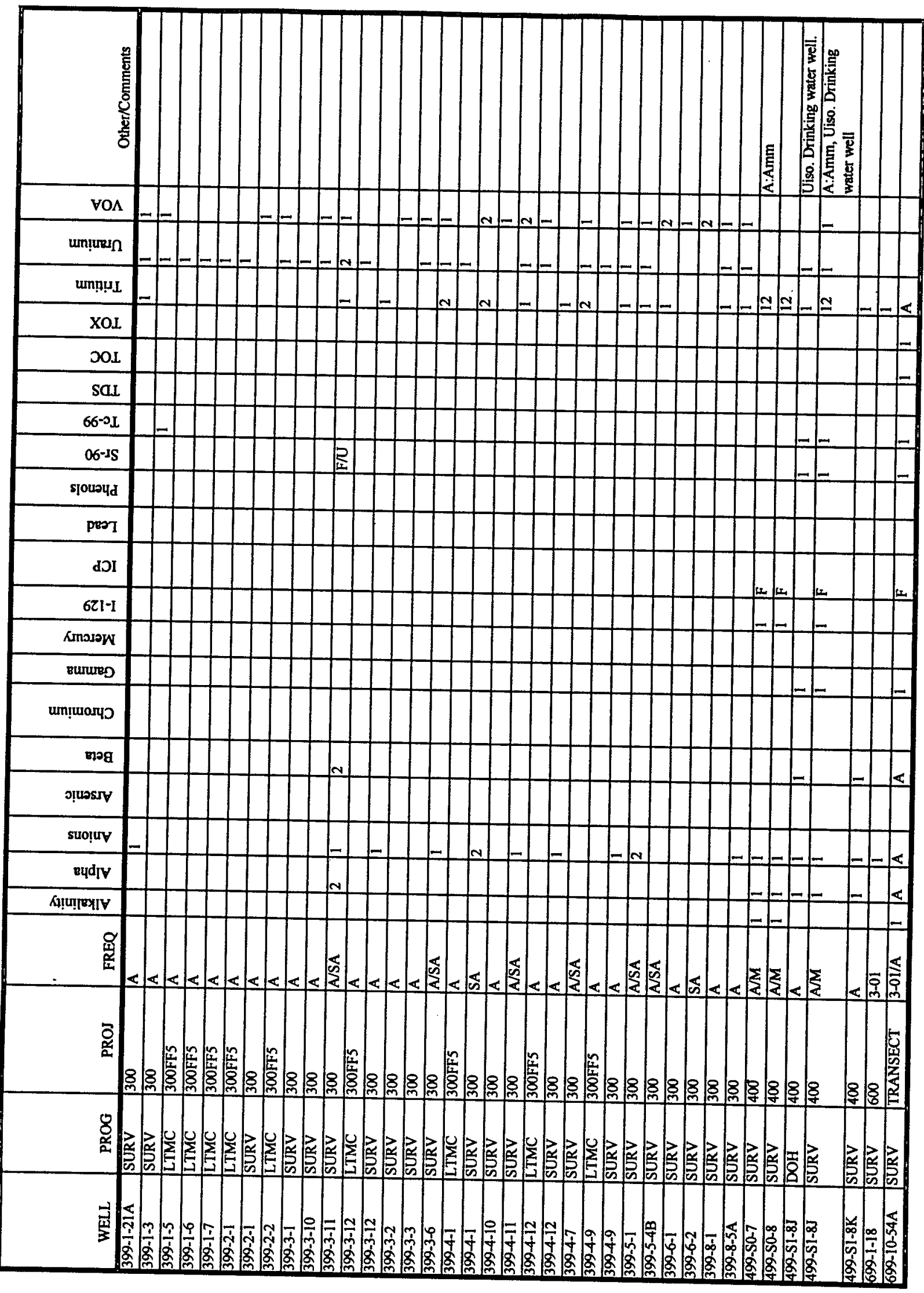




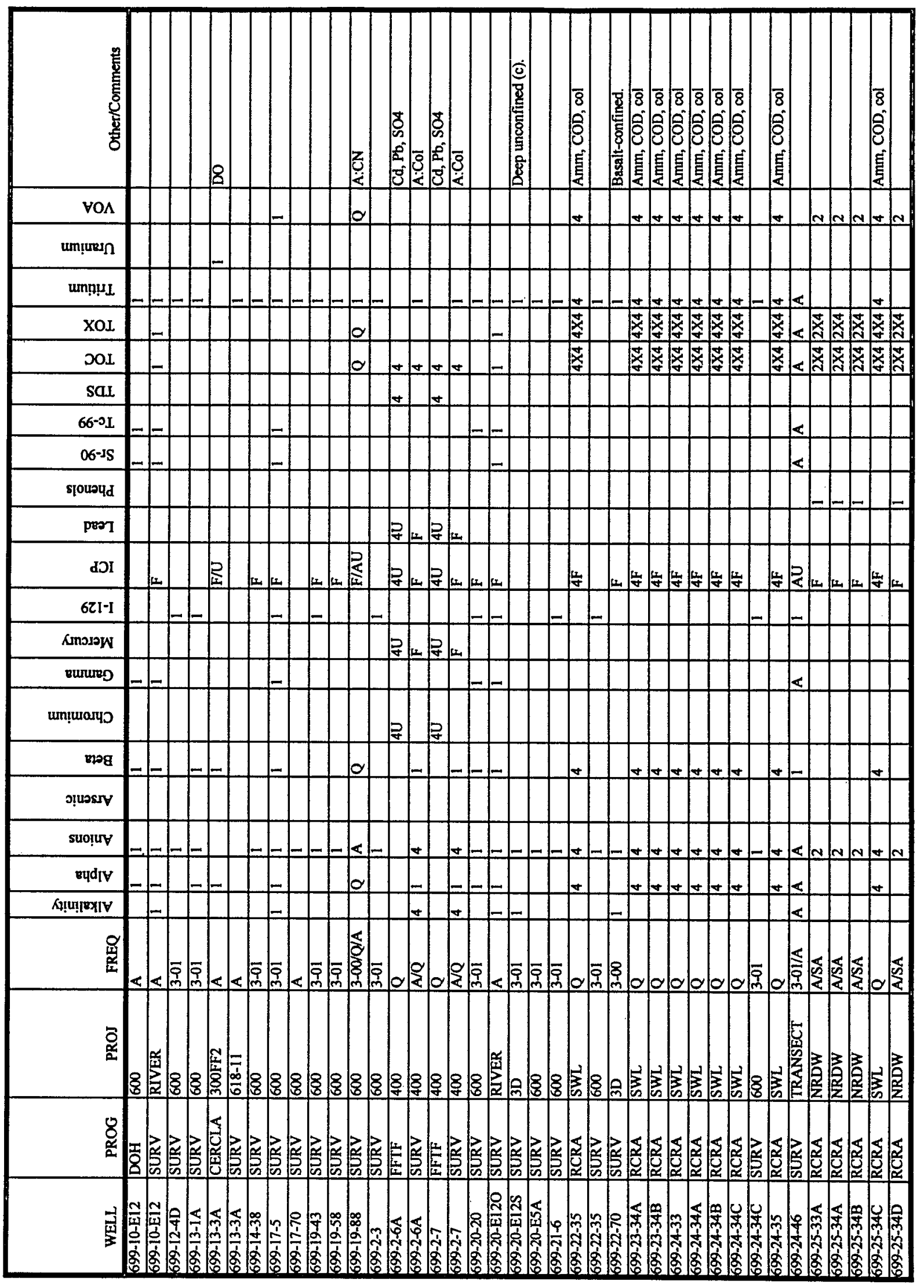




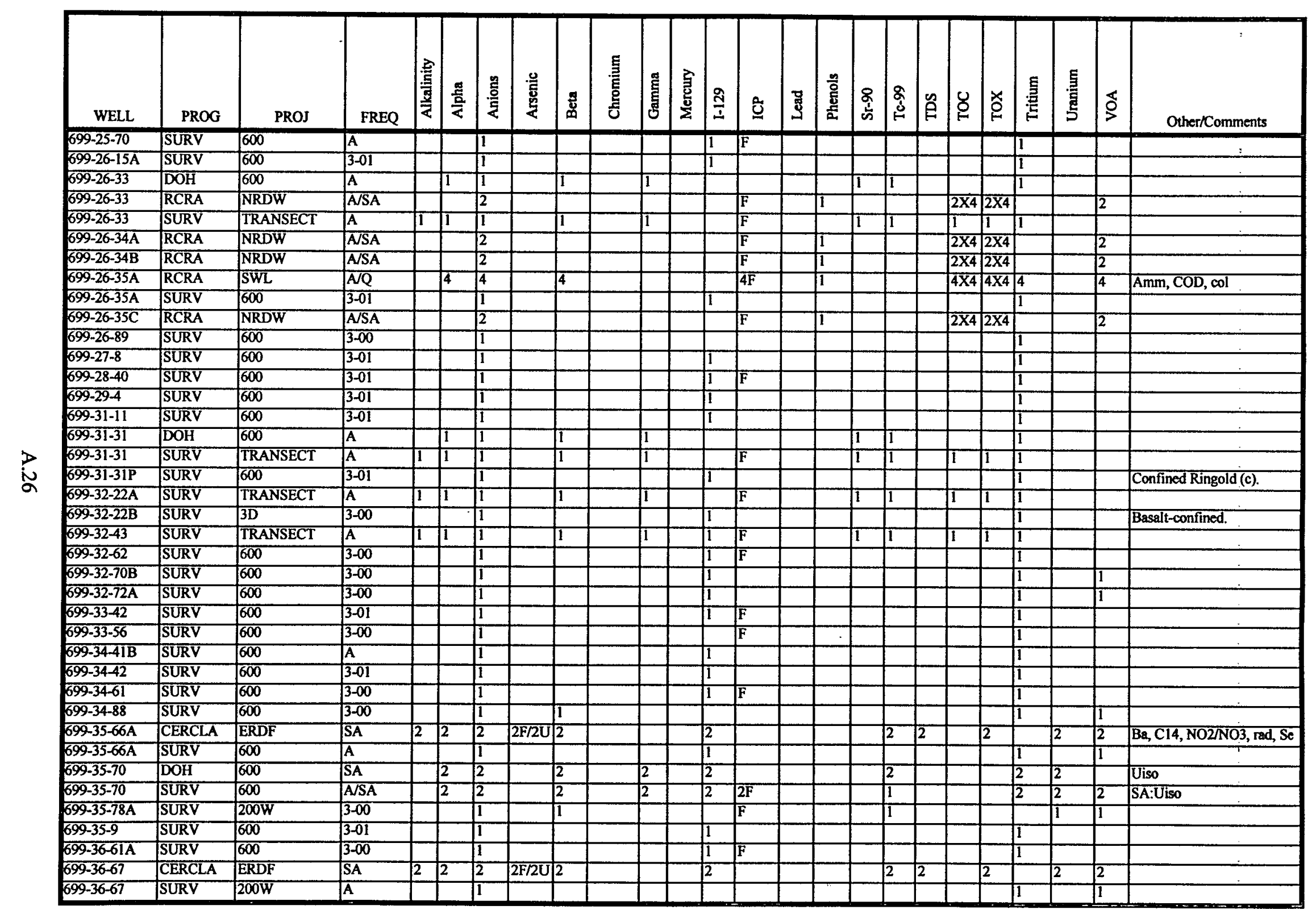




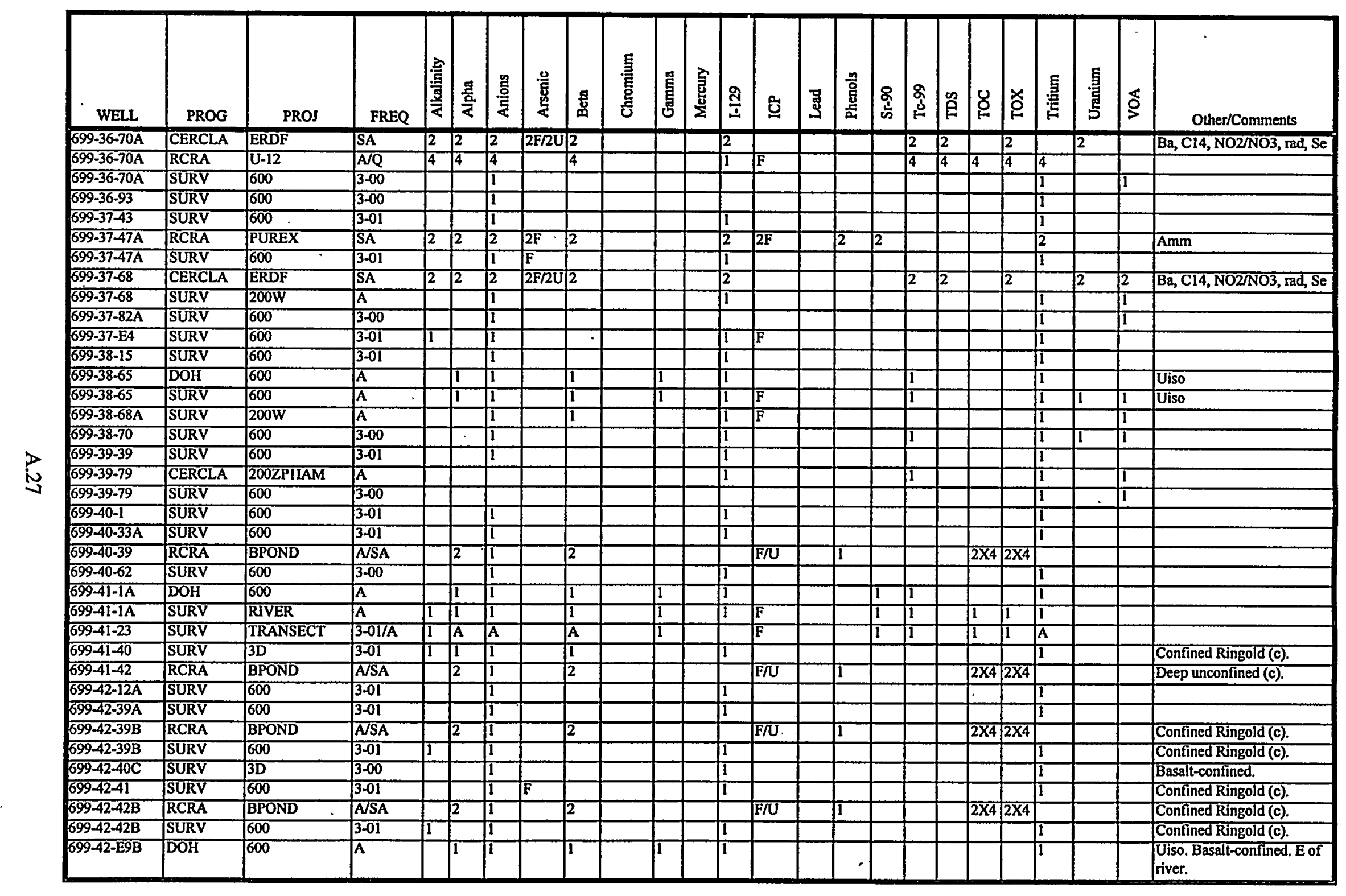




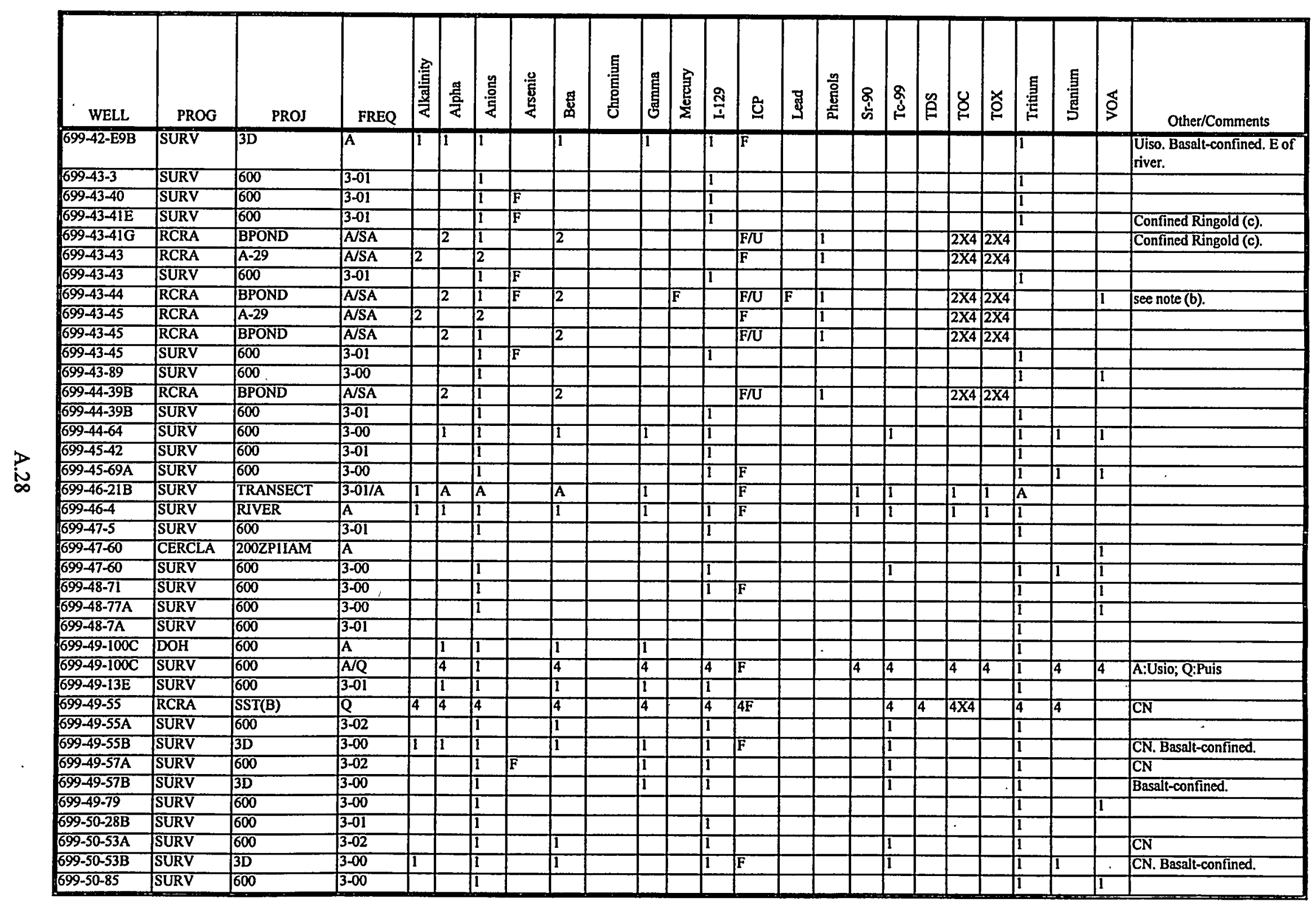




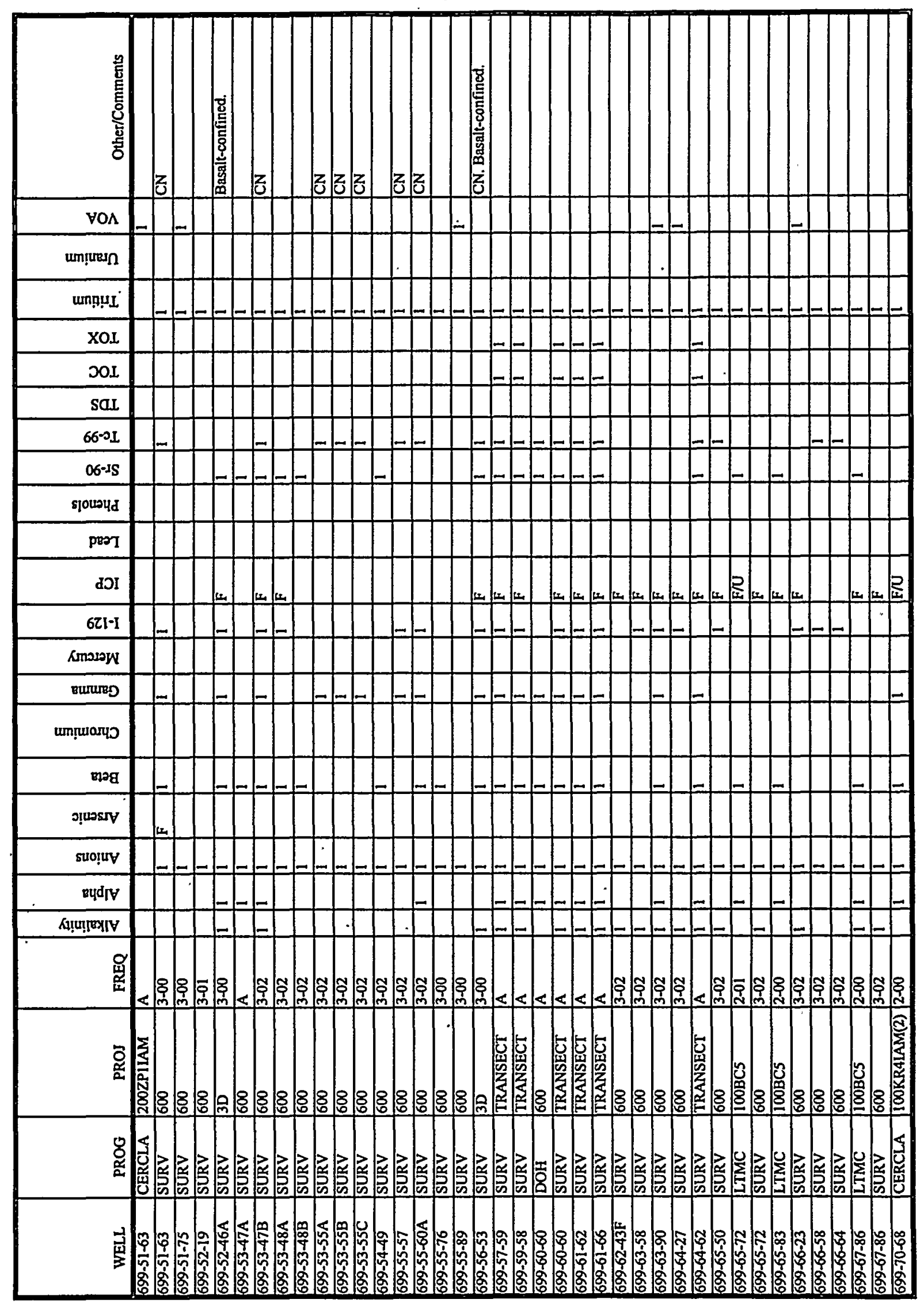




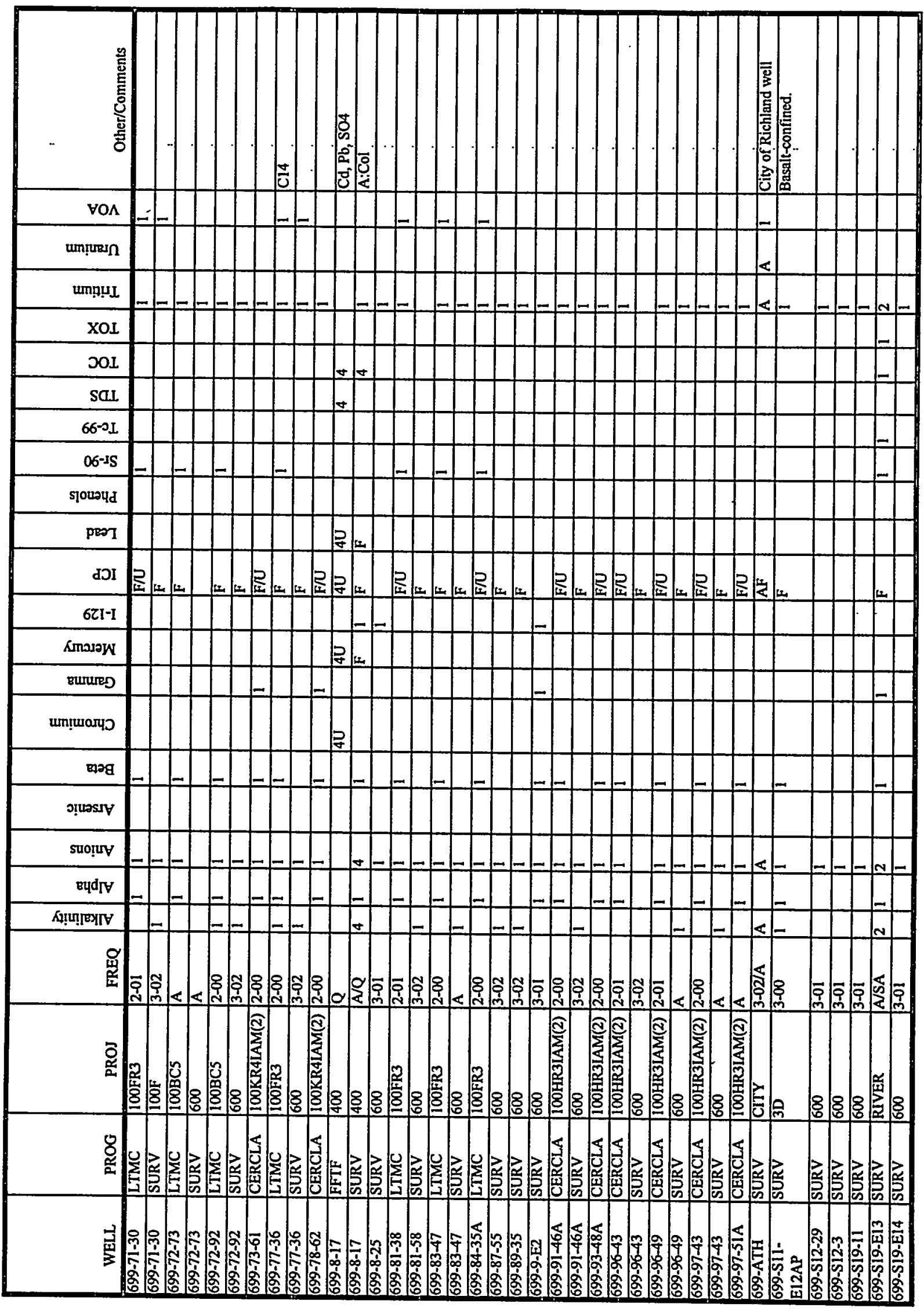




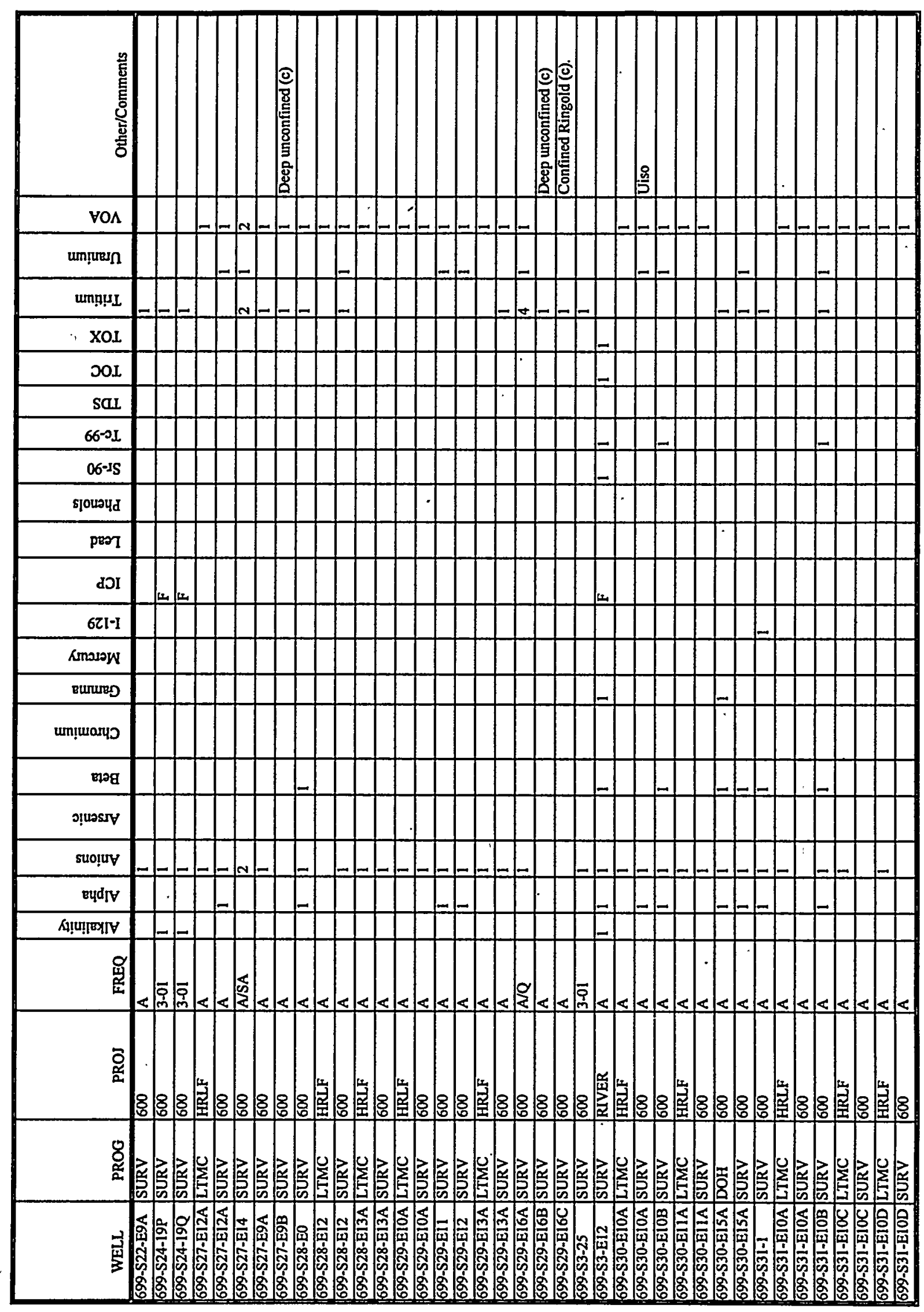




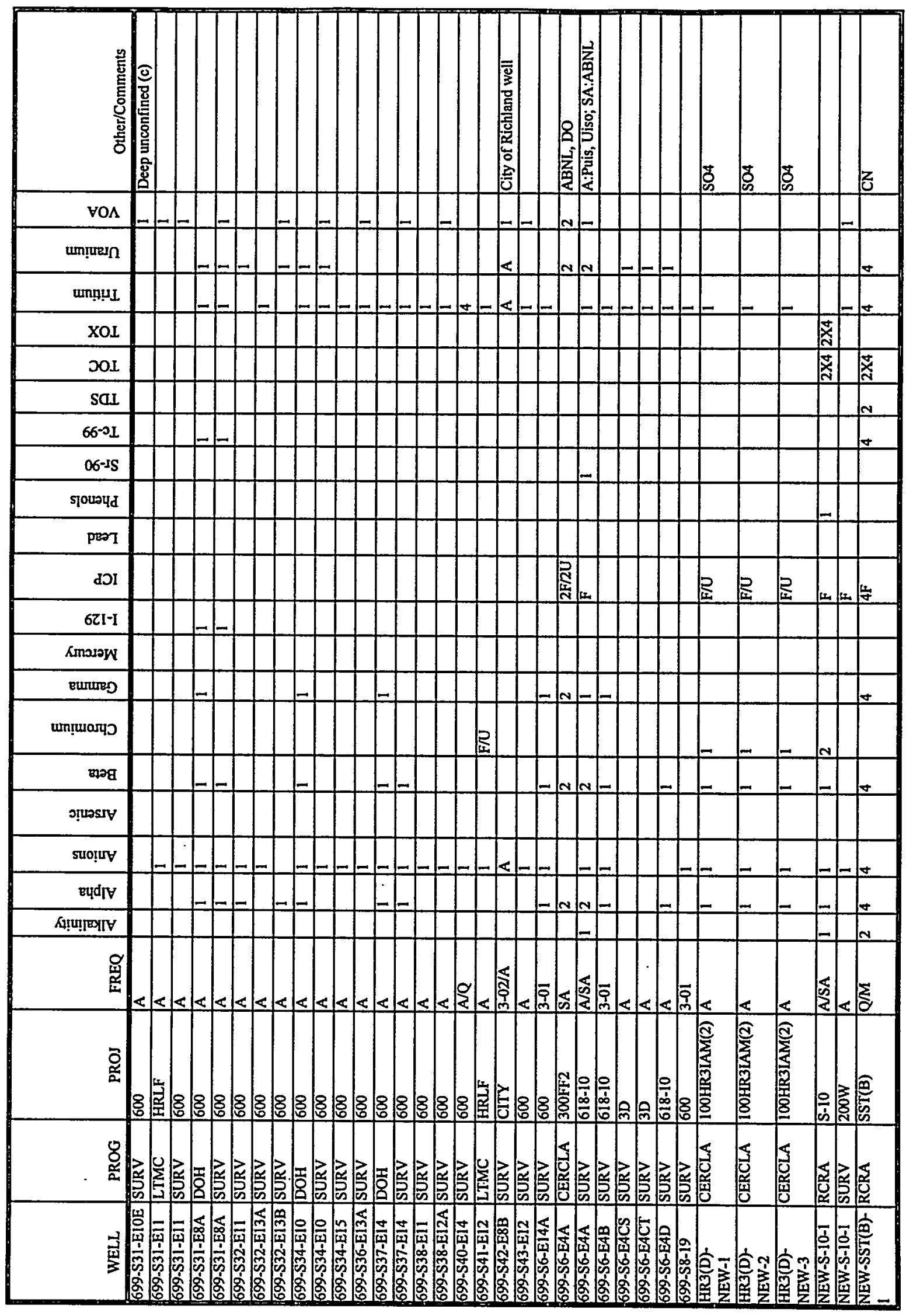




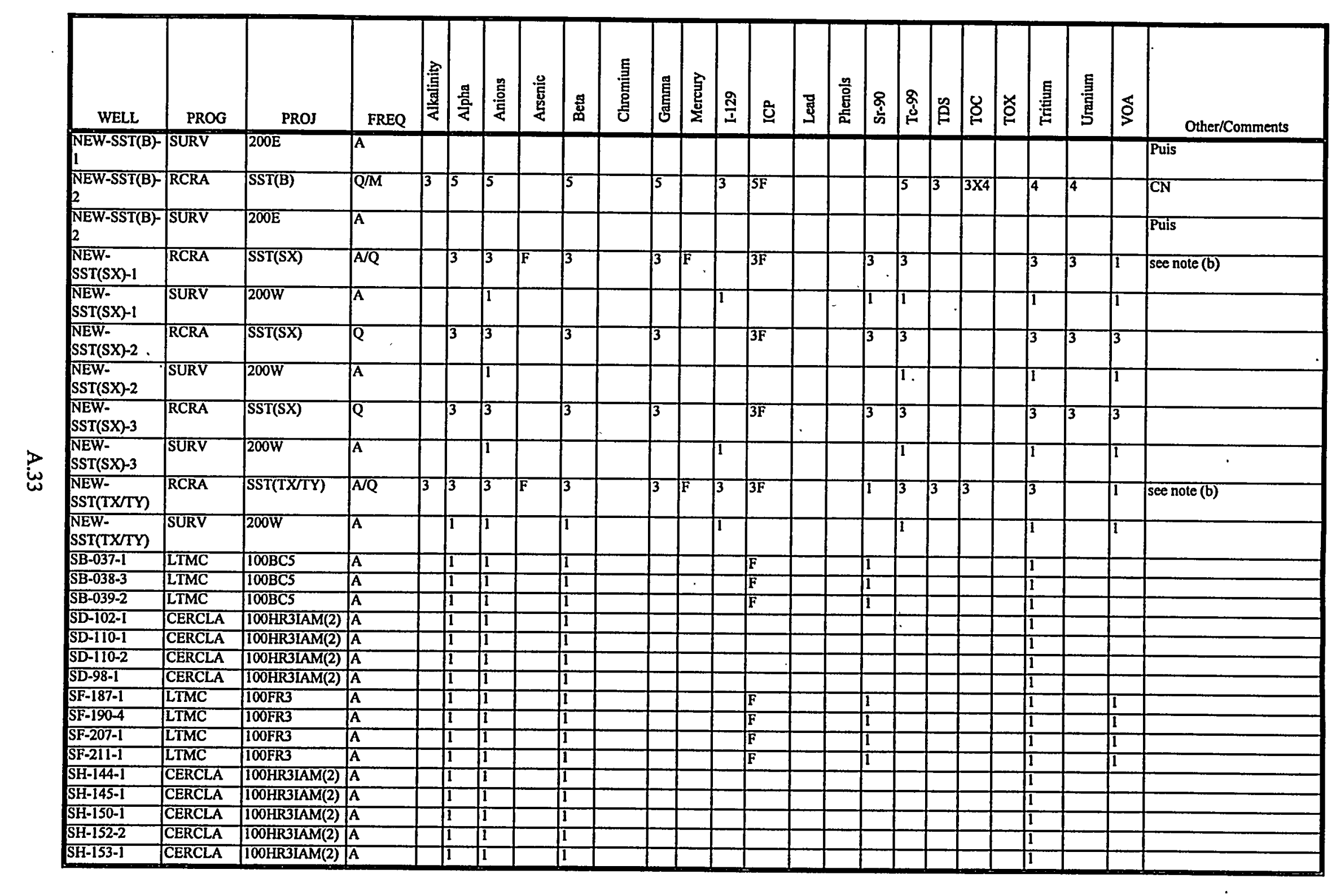




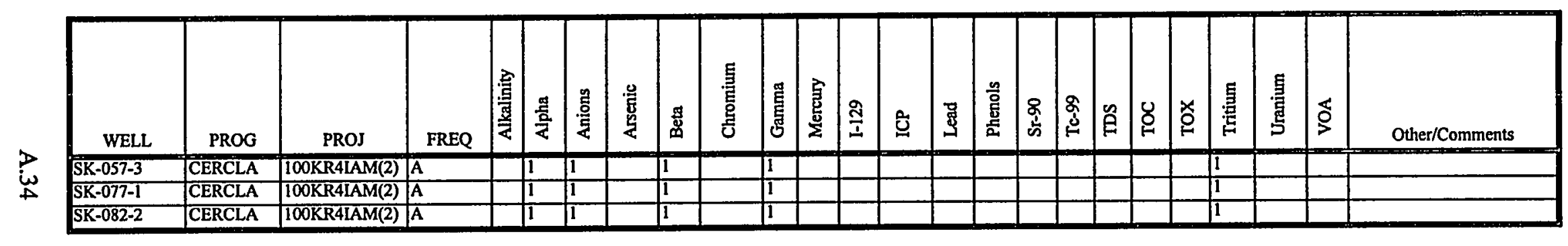




\section{Distribution}

No. of

Copies

\section{OFFSITE}

R. A. Danielson

State of Washington Department of Health

2 South 45th Avenue

Yakima, WA 98908

Scott VanVerst

State of Washington Department of Health

P.O. Box 47827

Olympia, WA 98504-7827

Mr. Russell Jim, Manager

Environmental Restoration/Waste

Management Program

Confederated Tribes and Bands

of the Yakama Nation

2808 Main Street

Union Gap, WA 98903

Ms. Lenora Seelatsee

Wanapam Band

Grant County P.U.D.

30 "C" Street, S.W.

P.O. Box 878

Ephrata, WA 98823

Mr. Patrick Sobotta, Interim Director

Environmental Restoration/Waste

Management Program

Nez Perce Tribe

P.O. Box 365

Lapwai, ID 83540
No. of

Copies

Mr. J. R. Wilkinson, Manager

Special Sciences and Resources Program

Confederated Tribes of the Umatilla Indian

Reservation

P.O. Box 638

.Pendleton, OR 97801

\section{ONSITE}

9 DOE Richland Operations Office

B. L. Foley

$\mathrm{H} 0-12$

M. J. Furman

$\mathrm{H} 0-12$

R. D. Hildebrand

H0-12

R. W. Lober

H6-60

D. E. Olson

$\mathrm{H} 0-12$

K. M. Thompson

HO- 12

A. C. Tortoso

$\mathrm{H} 0-12$

Public Reading Room (2)

$\mathrm{H} 2-53$

2 Bechtel Hanford, Inc.

B. H. Ford

H0-21

A. J. Knepp

H0-22

5 CH2M Hill Hanford, Inc.

J. V. Borghese

$\mathrm{H} 0-21$

R. F. Raidl

H9-02

V. J. Rohay

$\mathrm{H} 0-21$

L. C. Swanson

H9-02

J. P. Zoric 
No. of

Copies

2 Fluor Daniel Hanford, Inc.
S. M. Price
F. A. Ruck
4 State of Washington Department of Ecology

$\mathrm{A} 0-22$

$\mathrm{A} 0-22$
S. Leja
W. W. Soper
P. R. Staats
T. A. Wooley

B5-18

B5-18

B5-18

B5-18

3 U.S. Environmental Protection Agency

D. A. Faulk

B5-01

L. E. Gadbois

B5-01

D. R. Sherwood

B5-01

3 Waste Management Federal Services of Hanford, Inc.
D. L. Flyckt
L6-04
B. M. Barnes
T4-04
J. C. Sonnichsen
G1-30

2 Waste Management Federal Services, Inc., Northwest Operations

M. G. Gardner

H1-11

S. H. Worley
No. of

Copies

43 Pacific Northwest National Laboratory

D. B. Barnett

K6-81

C. J. Chou

K6-81

S. F. Conley

K6-75

P. E. Dresel

K6-96

J. S. Fruchter

K6-96

R. W. Hanf

$\mathrm{K} 6-75$

M. J. Hartman (5) K6-96

P. S. Henry

$\mathrm{K} 6-75$

F. N. Hodges

D. G. Horton

K6-81

V. G. Johnson

K6-81

K6-96

J. W. Lindberg

K6-81

S. P. Luttrell (5)

K6-96

J. P. McDonald

K6-96

R. B. Mercer

K6-96

D. J. Morgan

K6-96

S. M. Narbutovskih K6-96

D. R. Newcomer

K6-96

R. E. Peterson

J. T. Rieger

R. M. Smith

D. L. Stewart

M. D. Sweeney

C. J. Thompson

E. C. Thornton

W. D. Webber

B. A. Williams

M. D. Williams

K6-96

K6-96

K6-96

K6-96

K6-81

K6-96

K6-96

K6-96

K6-81

Information Release Office (7)
K9-36

K1-06 